\title{
Historical Archaeological Resources of the Choke Canyon Reservoir Area in McMullen and Live Oak Counties, Texas
}

Philip A. Bandy

Center for Archaeological Research

Follow this and additional works at: https://scholarworks.sfasu.edu/ita

Part of the American Material Culture Commons, Archaeological Anthropology Commons, Environmental Studies Commons, Other American Studies Commons, Other Arts and Humanities Commons, Other History of Art, Architecture, and Archaeology Commons, and the United States History Commons

Tell us how this article helped you.

This Article is brought to you for free and open access by the Center for Regional Heritage Research at SFA ScholarWorks. It has been accepted for inclusion in Index of Texas Archaeology: Open Access Gray Literature from the Lone Star State by an authorized editor of SFA ScholarWorks. For more information, please contact cdsscholarworks@sfasu.edu. 


\section{Historical Archaeological Resources of the Choke Canyon Reservoir Area in}

McMullen and Live Oak Counties, Texas

\section{Creative Commons License}

\section{(c) (1) \&}

This work is licensed under a Creative Commons Attribution-NonCommercial 4.0 International License 
PART II

HISTORICAL ARCHAEOLOGICAL RESOURCES OF THE

CHOKE CANYON RESERVOIR AREA IN

MCMULLEN AND LIVE OAK COUNTIES, TEXAS

By

Philip A. Bandy

Report of a project carried out by the Cultural Resources Institute

Texas Tech University 


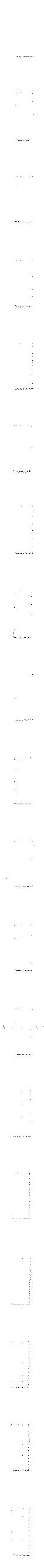




\section{ABSTRACT}

During previous surveys of the Choke Canyon Reservoir area in Live Oak and McMullen Counties, Texas, 17 historic sites (structures, refuse areas, cemeteries) had been located and examined. Further work in this area is described in this report and is summarized as follows:

Most of the above sites and 5 newly located ones underwent surface collection and test excavation. Sites were recorded and the collected artifacts described and classified. Suggested chronology and occupation are correlated with the findings of the historical research study (Everett, Part I of this report).

Evidence indicates that the area was most intensively occupied during the second half of the nineteenth century and that the inhabitants were Anglo-American, Black, Mexican, and possibly Mexican-American families. They were dependent on stock raising and strongly affected by the regional economy. 


\section{ACKNOWLEDGMENTS}

Daniel E. Fox directed the field work for this project; he was assisted by Paul D. Lukowski, William F. Fritts and J. Robert Lee. They wish to thank Max Quintanilla of Tilden, Texas, and his family for their help and hospitality. T. Jeffrey Campbell and George C. Knight assisted the author with the lab studies. Drafting was done by Brook Bowman and Ernest Macher, using the facilities of the Civil Engineering Department, Texas Tech University. Alice W. Portnoy served as project manager during the period of project activity. She also served as editor during the report writing and revising period. As editor she was especially helpful, drastically revising and improving initial draft manuscript prepared by the author. She also prepared the summary and conclusion section. The author is grateful to all of these persons and also to the many others who gave help and encouragement. 


\section{INTRODUCTION}

This study of the historic archeological site resources of a portion of the Nueces River project is one part of a three-part subcontract project between Texas Tech University and the University of Texas at San Antonio. The subcontract project was carried out during the period from July 1, 1977 to September 1, 1978 by TTU's Cultural Resources Institute. As are the other two parts of the project (history and prehistoric survey), the historic archeology part is based on the Scope of Work requirements of Bureau of Reclamation RFP 非0-V0897 and the subsequent proposal and research design submitted to UTSA by CRI (Mayer-Oakes 1977).

Previous archeological and historical research in the Nueces River project area has been very limited until recently. The first reported archeological investigations were conducted by Wakefield in 1968. His investigations were preliminary in nature and scope but reported the historic archeological sites $41 \mathrm{MC} 15$ and $41 \mathrm{MC} 17$. In 1974, the Texas Historical Commission and Texas Water Development Board collaborated and began surveying the reservoir area (Sorrow, O'Malley and Fox 1974 as cited in Lynn, Fox and O'Malley 1977:1). This field effort was resumed in 1976 by the Texas Historical Commission under contract with the Bureau of Reclamation. A result of that contract was a report (Lynn, Fox and $0^{\prime}$ Malley 1977) which included findings, initial evaluation and a summary of 17 historic sites. The historic sites comprised 11 historic structures or refuse areas and 6 cemeteries (Fig. 5). In addition, the land ownership history was checked to determine the identity of early inhabitants. It was on the basis of the THC work and recommendations that the Scope of Work for the CRI project (1977-1978) was determined.

Daniel Fox, part of the first (1974) and second (1976) THC teams, directed and carried out the field work for this investigation. Fox worked on 15 historic sites; ten were specified in the Scope of Work, five were newly located. While site $41 \mathrm{LK} 73$ on the Johnston ranch was scheduled by the RFP and proposal for a surface collection, access to the site was denied by the owner at the time of field work. Fox test-excavated 7 sites and surface collected 8; Philip Bandy surface collected 1 new historic site (Table 2). Results of their field work are presented in this report. The 6 new historic sites have been added to the THC map (Fig. 5). Study of these data gathered by Fox was carried out by Bandy who also prepared this report. The oral histories, land ownerships, historic records, and government documents were investigated by Dianna Everett and Stephen Head of the TTU-CRI history sub-project. Everett has prepared a separate report dealing with these aspects of the historical record. Tables 2-5 summarize TTU Historic Sites Archeology and Historical Research field work. 
Figure 5. Project Area Map with Sites Located.

PAGE 72 REDACTED 
TABLE 2. HISTORIC SITES STUDIED, TTU-CRI PROJECT 1977-78.

\begin{tabular}{|c|c|c|c|c|}
\hline $\begin{array}{l}\text { New sites } \\
\text { located }\end{array}$ & $\begin{array}{l}\text { Mapped and surface } \\
\text { collected }\end{array}$ & $\begin{array}{l}\text { Tested and sur- } \\
\text { face collected }\end{array}$ & \multicolumn{2}{|c|}{ Covered by historian } \\
\hline $41 L K 123$ & * 41LK159 & 41LK66 "Nichols House" & $41 L K 15$ & $41 \mathrm{MC} 71$ \\
\hline $41 L K 140$ & $41 M C 46$ & $41 M C 15$ & $41 L K 53$ & $41 \mathrm{MC} 72$ \\
\hline 41LK159 & 41MC91 & $41 \mathrm{MC} 17$ & 41LK66 & $41 M C 74$ \\
\hline $41 L K 163$ & 41MC166 "Dump Site" & $41 M C 72$ & $41 L K 73$ & $41 \mathrm{MC} 91$ \\
\hline $41 L K 168$ & 41MC168 "Teal Site" & $41 M C 74$ & $41 L K 159$ & $41 M C 166$ \\
\hline $41 L K 197$ & $41 M C 175$ & $41 M C 185$ & 41LK168 & $41 M C 168$ \\
\hline 41LK199 & $41 \mathrm{MC} 185$ & $41 \mathrm{MC} 192$ & $41 L K 197$ & $41 \mathrm{MC} 175$ \\
\hline 41Mc72 "New Site" & $41 M C 193$ & & 41LK199 & $41 \mathrm{MC} 185$ \\
\hline 41MC192 "Dusek Site" & 41MC194 & & $41 M C 4$ & $41 M C 192$ \\
\hline 41MC193 "Bracken Site" & 41MC195 (surf. col1. only) & & $41 M C 6$ & $41 M C 193$ \\
\hline 41MC194 "Horton Site" & * 41MC214 & & $41 M C 15$ & 41MC 194 \\
\hline 41MC195 "Teal House" & . & & $41 \mathrm{MC} 17$ & 41MC 195 \\
\hline $41 M C 214$ & & & $41 M C 46$ & $41 \mathrm{MC} 214$ \\
\hline $\begin{array}{l}\text { * Historic component of } \\
\text { (Thoms and Montgomery) }\end{array}$ & site located by survey project & & $\begin{array}{l}41 M C 55 \\
41 M C 66\end{array}$ & $\begin{array}{l}\text { Yarbrough Bend Cem. } \\
\text { (no number) }\end{array}$ \\
\hline
\end{tabular}


TABLE 3. DESCRIPTION OF SITES.

\begin{tabular}{|c|c|c|c|c|c|c|c|}
\hline $\begin{array}{l}\text { SITE NUMBER } \\
\text { AND NAME }\end{array}$ & $\begin{array}{l}\text { PHYSIOGRAPHIC } \\
\text { SITUATION }\end{array}$ & $\begin{array}{l}\text { UNDERL YING } \\
\text { GEOLOGIC OUTCROP }\end{array}$ & $\begin{array}{l}\text { NEAREST } \\
\text { STREAM } \\
\text { CHANNEL }\end{array}$ & $\begin{array}{l}\text { DISTAN } \\
\text { SITE T } \\
\text { horiz }\end{array}$ & $\begin{array}{l}(\mathrm{m})-- \\
\text { TREAM } \\
\text { vert }\end{array}$ & $\begin{array}{l}\text { PROBABLE } \\
\text { WATER SOURCE }\end{array}$ & $\begin{array}{l}\text { NEAREST } \\
\text { CONTEMPORANEOUS } \\
\text { SITES OR } \\
\text { CULTURAL FEATURES }\end{array}$ \\
\hline $\begin{array}{l}41 \text { LK66 } \\
\text { Nichols House }\end{array}$ & $\begin{array}{l}\text { valley wall, } \\
\text { Frio River }\end{array}$ & $\begin{array}{l}\text { Catahoula } \\
\text { formation }\end{array}$ & Frio R. & 244 & 13 & cistern & $\begin{array}{l}41 L K 15,73, \\
\text { poss. sites on } \\
\text { Schwartz Ranch }\end{array}$ \\
\hline $41 \mathrm{MC} 15$ & $\begin{array}{l}\text { fossil flood } \\
\text { plain margin }\end{array}$ & $\begin{array}{l}\text { Lipan member, } \\
\text { Fayette form. }\end{array}$ & Frio R. & 12 & 9 & Frio R. & $\begin{array}{l}41 \mathrm{MC} 17,71 \mathrm{cem} ., \\
\text { Yarbrough Bend } \\
\text { Cem. }\end{array}$ \\
\hline $41 M C 17$ & $\begin{array}{l}\text { fossil flood } \\
\text { plain margin }\end{array}$ & $\begin{array}{l}\text { Lipan member, } \\
\text { Fayette form. }\end{array}$ & Frio R. & 34 & 11 & Frio R. & $\begin{array}{l}41 \mathrm{MC} 15,71 \text { cem., } \\
72,74, \text { Yarbrough } \\
\text { Bend Cem. }\end{array}$ \\
\hline $47 M C 46$ & $\begin{array}{l}\text { valley wall, } \\
\text { Opossum Creek }\end{array}$ & $\begin{array}{l}\text { Whitsett mem., } \\
\text { Fayette form. }\end{array}$ & Opossum Ck。 & 91 & 4 & dug well & $\begin{array}{l}41 \mathrm{MC} 175,185, \text { poss. } \\
\text { sites on 0possum } \\
\text { Creek }\end{array}$ \\
\hline $\begin{array}{l}47 \mathrm{MC} 72 \\
\text { "New" Site }\end{array}$ & $\begin{array}{l}\text { fossil flood } \\
\text { plain margin }\end{array}$ & NA & Frio R. & 40 & 7 & Frio R. & $\begin{array}{l}41 \mathrm{MC} 15,17,71 \text { cem. } \\
74\end{array}$ \\
\hline $41 M C 74$ & $\begin{array}{l}\text { fossil flood } \\
\text { plain margin }\end{array}$ & $\begin{array}{l}\text { Lipan member } \\
\text { Fayette form. }\end{array}$ & Frio R. & 46 & 10 & Frio R. & $\begin{array}{l}41 \mathrm{MC} 15,17,71 \mathrm{cem} . \\
72\end{array}$ \\
\hline
\end{tabular}


TABLE 3. (continued)

\begin{tabular}{|c|c|c|c|c|c|c|c|}
\hline $\begin{array}{l}\text { SITE NUMBER } \\
\text { AND NAME }\end{array}$ & $\begin{array}{l}\text { PHYSIOGRAPHIC } \\
\text { SITUATION }\end{array}$ & $\begin{array}{l}\text { UNDERLYING } \\
\text { GEOLOGIC OUTCROP }\end{array}$ & $\begin{array}{l}\text { NEAREST } \\
\text { STREAM } \\
\text { CHANNEL }\end{array}$ & $\begin{array}{l}\text { DISTAN } \\
\text { SITE T } \\
\text { horiz }\end{array}$ & $\begin{array}{l}\text { (m)--- } \\
\text { TREAM } \\
\text { vert }\end{array}$ & $\begin{array}{l}\text { PROBABLE } \\
\text { WATER SOURCE }\end{array}$ & $\begin{array}{l}\text { NEAREST } \\
\text { CONTEMPORANEOUS } \\
\text { SITES OR } \\
\text { CULTURAL FEATURE }\end{array}$ \\
\hline 41MC91 & $\begin{array}{l}\text { valley wall, } \\
\text { Frio R. }\end{array}$ & $\begin{array}{l}\text { Lipan mem., } \\
\text { Fayette form. }\end{array}$ & $\begin{array}{l}\text { cut-off } \\
\text { channel of } \\
\text { San Miguel } \\
\text { Frio R. }\end{array}$ & * & NA & $\begin{array}{l}\text { cistern } \\
\text { or well }\end{array}$ & $\begin{array}{l}41 \mathrm{MC} 166,185, \\
\text { Yarbrough Bend } \\
\text { sites and cem. }\end{array}$ \\
\hline $\begin{array}{l}\text { 41MC166 } \\
\text { "Dump" Site }\end{array}$ & $\begin{array}{l}\text { Pleistocene } \\
\text { terrace margin }\end{array}$ & $\begin{array}{l}\text { Lipan member, } \\
\text { Fayette form. }\end{array}$ & $\begin{array}{l}\text { San Miguel } \\
\text { Creek }\end{array}$ & 20 & NA & San Miguel $\mathrm{Ck}$. & $\begin{array}{l}41 \mathrm{MC} 15,91,168, \\
\text { Yarbrough Bend } \\
\text { cem. }\end{array}$ \\
\hline $\begin{array}{l}41 M C 168 \\
\text { Teal Site }\end{array}$ & $\begin{array}{l}\text { Pleistocene } \\
\text { terrace margin }\end{array}$ & $N A$ & $\begin{array}{l}\text { San Miguel } \\
\text { Creek }\end{array}$ & 70 & NA & San Miguel $\mathrm{Ck}$. & $41 M C 15,91,166$ \\
\hline $41 M C 175$ & $\begin{array}{l}\text { Pleistocene } \\
\text { terrace remnant }\end{array}$ & $\begin{array}{l}\text { Whitsett member, } \\
\text { Fayette form. }\end{array}$ & Frio R. & 716 & 10 & cistern & $41 M C 46,185$ \\
\hline $41 M C 185$ & $\begin{array}{l}\text { valley wall, } \\
\text { Frio R. }\end{array}$ & $\begin{array}{l}\text { Whitsett and } \\
\text { Lipan members, } \\
\text { Fayette form. }\end{array}$ & Frio R. & 128 & 11 & Frio R. & $\begin{array}{l}\text { 41MC46, } 175 \\
\text { Byrne cem. }\end{array}$ \\
\hline $\begin{array}{l}41 M C 192 \\
\text { Dusek Site }\end{array}$ & $\begin{array}{l}\text { fossil flood } \\
\text { plain margin or } \\
\text { valley wall }\end{array}$ & & Frio R. & 110 & 19 & $\begin{array}{l}\text { Frio R. } \\
\text { Blackhill H. }\end{array}$ & $\begin{array}{l}41 \mathrm{MC} 17,71 \text { cem. } \\
72,74,193, \\
194\end{array}$ \\
\hline
\end{tabular}




\begin{tabular}{|c|c|c|c|c|c|c|c|}
\hline $\begin{array}{l}\text { SITE NUMBER } \\
\text { AND NAME }\end{array}$ & $\begin{array}{l}\text { PHYSIOGRAPHIC } \\
\text { SITUATION }\end{array}$ & $\begin{array}{l}\text { UNDERLYING } \\
\text { GEOLOGIC OUTCROP }\end{array}$ & $\begin{array}{l}\text { NEAREST } \\
\text { STREAM } \\
\text { CHANNEL }\end{array}$ & $\begin{array}{l}\text { DISTANC } \\
\text { SITE TC } \\
\text { horiz }\end{array}$ & $\begin{array}{l}\text { (m)-- } \\
\text { TREAM } \\
\text { vert }\end{array}$ & $\begin{array}{l}\text { PROBABLE } \\
\text { WATER SOURCE }\end{array}$ & $\begin{array}{l}\text { NEAREST } \\
\text { CONTEMPORANEOUS } \\
\text { SITES OR } \\
\text { CULTURAL FEATURES }\end{array}$ \\
\hline $\begin{array}{l}41 \mathrm{MC} 193 \\
\text { Bracken Site }\end{array}$ & $\begin{array}{l}\text { valley wall } \\
\text { (upland margin) }\end{array}$ & NA & Frio R. & 155 & 11 & Frio R. & $\begin{array}{l}\text { 41MC192, } 194 \\
\text { poss. sites } \\
\text { toward Tilden }\end{array}$ \\
\hline $\begin{array}{l}41 M C 194 \\
\text { Horton Site }\end{array}$ & $\begin{array}{l}\text { valley wa } 11 \\
\text { (upland margin) }\end{array}$ & NA & Frio R. & 119 & NA & Frio R. & $\begin{array}{l}41 M C 71 \text { cem., } \\
74,192,193, \\
\text { poss. sites toward } \\
\text { Tilden }\end{array}$ \\
\hline $\begin{array}{l}\text { 41MC195 } \\
\text { Teal House }\end{array}$ & NA & NA & Frio R. & NA & NA & Frio R. & NA \\
\hline
\end{tabular}

\footnotetext{
NA -- Not Available
} 
TABLE 4. CRI-TTU 1977 FIELD WORK.

\begin{tabular}{|c|c|c|c|c|c|c|}
\hline $\begin{array}{l}\text { SITE NUMBER } \\
\text { AND NAME }\end{array}$ & $\begin{array}{l}\text { HORIZONTAL } \\
\text { EXTENT } \\
(\mathrm{sq} \mathrm{m})\end{array}$ & CONDITION & $\begin{array}{l}\text { TYPE OF } \\
\text { WORK DONE }\end{array}$ & $\begin{array}{l}\text { DATES } \\
(1977)\end{array}$ & $\begin{array}{l}\text { AMOUNT OF } \\
\text { TIME SPENT } \\
\text { (days) by } \\
4 \text {-man crew }\end{array}$ & $\begin{array}{l}\text { RECOMMENDATIONS FOR } \\
\text { FURTHER FIELD WORK }\end{array}$ \\
\hline $\begin{array}{l}41 L K 66 \\
\text { Nichols House }\end{array}$ & 1200 & A & 1 & $7 / 06-7 / 15$ & 9.5 & 10 more days \\
\hline $41 M C 15$ & 500 & B & 1 & $8 / 15-8 / 18$ & 4.0 & $6-10$ more days \\
\hline $41 \mathrm{MC} 17$ & 1000 & C & 1 & $\begin{array}{l}8 / 01-8 / 10 \\
8 / 17\end{array}$ & 10.5 & $6-10$ more days \\
\hline $47 M C 46$ & 1200 & D & 2 & $7 / 19$ & 1.0 & 0 \\
\hline $\begin{array}{l}41 \mathrm{MC} 72 \\
\text { "New" Site }\end{array}$ & 3000 & D & 1 & $8 / 23$ & 0.8 & 1 more day \\
\hline $41 M C 74$ & 700 & $E$ & 1 & $8 / 10-8 / 12$ & 2.5 & 3 more days \\
\hline $41 M C 91$ & 800 & $E$ & 2 & $7 / 27$ & 1.0 & 0 \\
\hline $\begin{array}{l}41 M C 166 \\
\text { "Dump" Site }\end{array}$ & 40 & $E$ & 2 & $8 / 29$ & 0.5 & 0 \\
\hline
\end{tabular}


TABLE 4. (continued)

\begin{tabular}{|c|c|c|c|c|c|c|}
\hline $\begin{array}{l}\text { SITE NUMBER } \\
\text { AND NAME }\end{array}$ & $\begin{array}{l}\text { HORIZONTAL } \\
\text { EXTENT } \\
(\mathrm{sq} \mathrm{m})\end{array}$ & CONDITION & $\begin{array}{ll}\text { TYPE } & \text { OF } \\
\text { WORK } & \text { DONE }\end{array}$ & $\begin{array}{l}\text { DATES } \\
(1977)\end{array}$ & $\begin{array}{l}\text { AMOUNT OF } \\
\text { TIME SPENT } \\
\text { (days) }\end{array}$ & $\begin{array}{l}\text { RECOMMENDATIONS FOR } \\
\text { FURTHER FIELD WORK }\end{array}$ \\
\hline \multicolumn{2}{|l|}{$\begin{array}{l}41 \mathrm{MC} 168 \\
\text { Teal Site }\end{array}$} & $\mathrm{D}$ & 2 & $8 / 29$ & 0.3 & 1 more day \\
\hline $41 \mathrm{MC} 175$ & 1000 & A & 2 & $7 / 20-7 / 22$ & 3.0 & 0 \\
\hline $41 M C 185$ & 1800 & $\mathrm{E}$ & 1 & $7 / 25-7 / 26$ & 2.0 & 0 \\
\hline $\begin{array}{l}41 \mathrm{MC} 192 \\
\text { Dusek Site }\end{array}$ & 1200 & C & 1 & $\begin{array}{l}8 / 19-8 / 22 \\
8 / 24\end{array}$ & 3.0 & $10-20$ more days \\
\hline $\begin{array}{l}41 \mathrm{MC} 193 \\
\text { Bracken Site }\end{array}$ & 2400 & C & 2 & $8 / 25$ & 0.5 & $6-10$ more days \\
\hline $\begin{array}{l}41 \mathrm{MC} 194 \\
\text { Horton Site }\end{array}$ & 900 & C & 2 & $8 / 25$ & 0.2 & 1 more day \\
\hline \multirow[t]{2}{*}{$\begin{array}{l}41 \mathrm{MC} 195 \\
\text { Tea } 1 \text { House }\end{array}$} & 1200 & $E$ & 3 & $10 / 26$ & $\left(\begin{array}{l}0.2 \\
1 \operatorname{man})\end{array}\right.$ & 0 \\
\hline & & & & KEY & & \\
\hline $\begin{array}{ll}\text { A } & \text { rela } \\
\text { B } & \text { some } \\
\text { C } & \text { part } \\
\text { D } & \text { dist } \\
\text { F } & \text { hadl }\end{array}$ & \multicolumn{4}{|c|}{$\begin{array}{l}\text { relatively well-preserved } \\
\text { some areas preserved } \\
\text { partially disturbed by clearing/erosion } \\
\text { disturbed by clearing/erosion } \\
\text { badlv disturbed bv clearina erosion }\end{array}$} & $\begin{array}{ll}1 & \text { surface } \\
& \text { testing } \\
2 & \text { surface } \\
3 & \text { surface }\end{array}$ & $\begin{array}{l}\text { collection and intensive } \\
\text { collection and mapping } \\
\text { collection }\end{array}$ \\
\hline
\end{tabular}


TABLE 5. SUGGESTED CULTURE/CHRONOLOGY.

\begin{tabular}{|c|c|c|c|}
\hline $\begin{array}{l}\text { SITE NUMBER } \\
\text { AND NAME }\end{array}$ & $\begin{array}{l}\text { CULTURAL/CHRONOLOGICAL } \\
\text { AFFILIATIONS SUGGESTED } \\
\text { BY ARCHEOLOGICAL FIELD } \\
\text { WORK AT SITE }\end{array}$ & $\begin{array}{l}\text { CULTURAL/CHRONOLOGICAL } \\
\text { AFFILIATIONS SUGGESTED } \\
\text { BY HISTORICAL RESEARCH }\end{array}$ & $\begin{array}{l}\text { DIAGNOSTIC } \\
\text { SPECIMENS } \\
\text { DETERMINED } \\
\text { BY LAB } \\
\text { ANALYSIS }\end{array}$ \\
\hline $\begin{array}{l}\text { 41LK66 } \\
\text { Nichols House }\end{array}$ & $\begin{array}{l}\text { 1870s-1930s, poss. } \\
\text { to present } \\
\text { Anglo-Amer }\end{array}$ & $\begin{array}{l}\text { 1858-1954 } \\
\text { Anglo-Amer }\end{array}$ & $\begin{array}{l}\text { glass } \\
\text { pre-1880 } \\
1860-90 \\
\text { nails } \\
\text { pre-1900 } \\
\text { many, varied } \\
1900-60\end{array}$ \\
\hline $47 M C 15$ & $\begin{array}{l}\text { 1850s-70s (80s (?) } \\
\text { Anglo/Mex-Amer }\end{array}$ & $\begin{array}{l}\text { 1870s \& 80s } \\
\text { Ang10-Amer } \\
\text { Mex }\end{array}$ & $\begin{array}{l}\text { ceramic } \\
1850-70 \\
1860-1900 \\
\text { nails } \\
\text { pre-1900 }\end{array}$ \\
\hline $41 M C 17$ & $\begin{array}{l}\text { 1870s \& 80s } \\
\text { Anglo/Mex-Amer }\end{array}$ & $\begin{array}{l}\text { 1870s \& 80s } \\
\text { Ang10-Amer } \\
\text { Mex }\end{array}$ & $\begin{array}{l}\text { ceramic } \\
1860-1900 \\
\text { pre-1900 } \\
1880-1910 \\
\text { glass } \\
1880-1910 \\
\text { nails } \\
\text { pre-1900 } \\
\text { cartridges } \\
\text { 1860-1920 }\end{array}$ \\
\hline $41 M C 46$ & $\begin{array}{l}\text { late } 1860 \text { s or } \\
\text { early } 70 \text { s to } 1890 \mathrm{~s} \\
\text { Anglo/Mex-Amer }\end{array}$ & $1880(?)$ to ? & $\begin{array}{l}\text { ceramic } \\
1860-90 \\
\text { glass } \\
\text { post-1910 } \\
\text { tin can } \\
\text { post-1880 }\end{array}$ \\
\hline $\begin{array}{l}\text { 41MC72 } \\
\text { "New" Site }\end{array}$ & $\begin{array}{l}\text { 1870s-90s } \\
\text { Ang10/Mex-Amer }\end{array}$ & $\begin{array}{l}\text { 1870s \& 80s } \\
\text { Ang10-Amer } \\
\text { Mex }\end{array}$ & $\begin{array}{l}\text { ceramics } \\
1850-1880 \\
1860-1900 \\
\text { glass } \\
1860-1900 \\
1880-1915 \\
\text { nails } \\
\text { pre-1900 }\end{array}$ \\
\hline
\end{tabular}


TABLE 5. (continued)

SITE NUMBER AND NAME

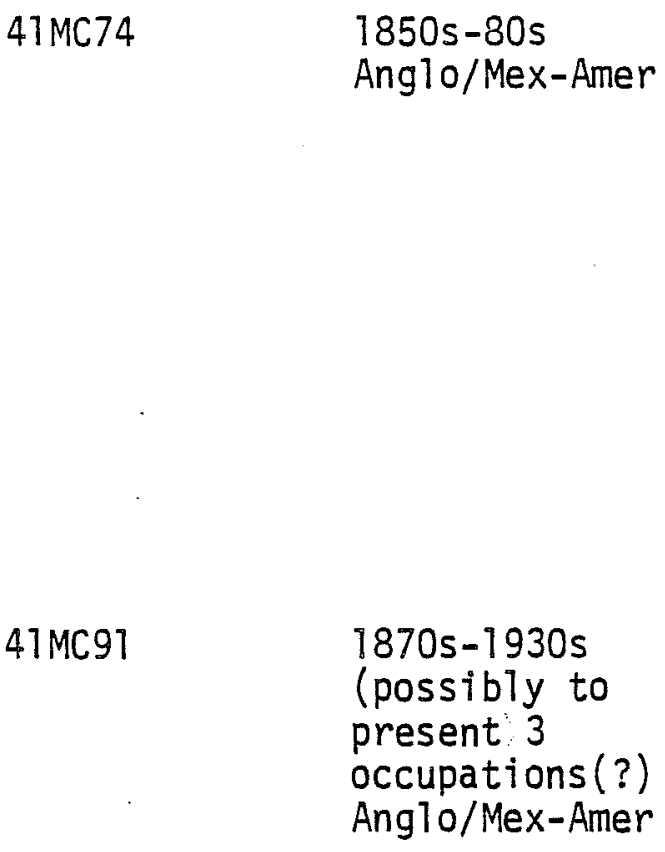

41MC166

"Dump" Site

$41 \mathrm{MC} 168$

Teal Site
CULTURAL/CHRONOLOGICAL AFFILIATIONS SUGGESTED BY ARCHEOLOGICAL FIELD WORK AT SITE

CULTURAL/CHRONOLOGICAL AFFILIATIONS SUGGESTED BY HISTORICAL RESEARCH

1860s - recent

1860s Anglo-Amer

1880s Mex,Black 1880s-90s

1880s-1910

1882

1882-88 Ang 10/Amer 1888 Black

1882 -

(see MC168)
DIAGNOSTIC SPECIMENS

DETERMINED BY LAB ANALYSIS

ceramics 1840-70 1850-70 1855

1860-70

1860-1900 pre-1900 glass 1860-1900 1880-1910 nails pre-1900 post-1900

glass 1880-1910 post-1910 nails

pre-1900 post-1900 cartridges 1870 to present

glass

1860-present 1880-1910 nails

pre-1900

ceramics post -1880 glass

pre- 1880 1880-1900 cartridges 1880 to present 
TABLE 5. (continued)

SITE NUMBER AND NAME

$41 M C 175$

$47 M C 785$

$41 M C 192$

Dusek Site
CULTURAL/CHRONOLOGICAL AFFILIATIONS SUGGESTED BY ARCHEOLOGICAL FIELD WORK AT SITE

1880(?)-

Tate 1860s-80s

Anglo/Mex-Amer

1850s-80s

Anglo/Mex-Amer
CULTURAL/CHRONOLOGICAL AFFILIATIONS SUGGESTED BY HISTORICAL RESEARCH

1870(?)-

1860s-80s

Anglo-Amer
DIAGNOSTIC

SPECIMENS

DETERMINED

BY LAB

ANALYSIS

glass

1890-1910

nails

pre-1900

many, varied

1910 to

present

ceramics

1850-1900

1860-1870

glass

1860-1900

1880-1910

nails

pre-1900

post-1900

tin cans

1870-90

1870-1900

pre-1920

Mexican

ceramics

present

ceramics

1850-70

1850-1900

1860-70

1860-7900

glass

1860-1900

1880-1900

nails

pre-1900

post-1900

tin cans

pre-1900

pre-1920

gun part

1830-70

coin (Mex)

1870

Mexican

ceramics

present 
TABLE 5. (continued)

SITE NUMBER AND NAME

41 MC193

Bracken Site

$47 M C 194$

$47 M C 195$

Teal House
CULTURAL/CHRONOLOGICAL AFFILIATIONS SUGGESTED BY ARCHEOLOGICAL FIELD WORK AT SITE

late 1860s or early 1870s-1880s Ang10/Mex-Amer
CULTURAL/CHRONOLOGICAL AFFILIATIONS SUGGESTED BY HISTORICAL RESEARCH

1860s-80s Anglo-Amer
DIAGNOSTIC SPECIMENS DETERMINED

BY LAB ANALYSIS

ceramics 1850-1900 glass

1860-1900

1880-1900 nails

pre-1900

tin can pre-1900 gun part 1860-1890

1860s-80s

Anglo-Amer

1878 -

Ang10-Amer ceramics

1860-90

nails

pre-1900 cartridge 1870-90 
The surveying of previously unsurveyed Nueces River project land by the Texas Tech survey team (directed by Alston Thoms and John Montgomery) recorded 7 more new sites with historic components (Table 2), 2 of which were surface collected and are described in their report. The intensive mapping, testing, and evaluation team from UTSA also encountered several more previously unreported historic sites.

The research design for the project was spelled out by Fox in the Texas Tech University proposal (later modified). The project may be viewed as a problem in frontier economy. Everett has in her report a discussion of theories on frontier economy operation, development, and structure. She demonstrates that the project area fits one theory or model which describes first, the development of towns or economic centers in a regional network, then second, the "filling-in" of the local economic matrix.

Frontier economy has been considered in a regional context, but details of local economy need further study. Based on what we know of the regional and local economy, the local people were bound by the regional and national economic system and were a primary resource base utilized, manipulated, and controlled by this system. We know that several major shifts in the regional economy had marked influence on the project area in terms of the way resources were utilized and what products were produced. For example, when the cattle market went bad, people shifted to raising turkeys and sheep, and then shifted back to cattle when the market improved.

Collection, analysis and interpretation of data, both historical and archeological, are resulting in increased understanding of regional history and of frontier economy generally. 
FIELD WORK

The field work, during summer of 1977, was a Phase I investigation of the historic structure/artifact scatter sites. The activities were directed toward a systematic evaluation of these sites by using both surface and subsurface recovery procedures. The intensity of examination was determined in part by the nature of each site, expecially its potential to be chronologically dated. In general, each site was examined for the presence and nature of architectural features, and the time period of occupation based on datable artifacts. These data were recorded on detailed plane table/alidade-produced contour maps and diagrams or floor plans, when applicable.

\section{Surface Collections}

The artifacts scattered on the surface were collected by several procedures. The larger, more intact, and intensively examined sites were collected with more rigorous controls than smaller, more disturbed sites. Many marginally significant sites were sampled by a "grab sample" procedure of picking up items which might give clues to age of the site. The exact provenience of these specimens was not recorded other than being from a particular site. The sites which were systematically surface collected were either divided into areas or sections and all artifacts collected by these general proveniences, or each artifact or cluster of artifacts was individually plotted on the site map. Sites which were divided into sub-areas were done so mostly by utilizing existing features such as plant or topographic zones, roads, fences, architecture, etc. Some sites were collected using a combination of techniques, by collecting all the "general type" artifacts (e.g., glass sherds, nails) and mapping in specific "important" specimens (e.g., gun parts and diagnostic ceramics). Artifacts with exact locational information are shown on the site maps when possible and are tabulated by collection units for each site when possible. All surface evidence of architecture could, of course, not be collected, but was recorded (i.e., drawn, measured, and photographed) and then plotted on the site maps.

\section{Excavations}

The excavations of historic sites were directed primarily toward the recovery of architectural data. The location of excavation units was determined by surface evidence concentrations, suggesting where subsurface features might be found. For example, rock alignments exposed on the surface may be parts of buried walls. The hypothesized 
buried walls were then "checked for" by excavation or sweeping away vegetation and debris with a broom to determine if these features were there. Most of the structures probably had earth floors which are usually poorly preserved. It was hoped that some sections of floor might be preserved. Since such floors are generally best preserved in room corners, some of the suggested or observed corners were excavated to find the floor. Areas that were suspected to be structures or where wall locations were not fully detectable were tested by trenching across the area. Where there was evidence of architecture such as walls or chimney foundations, these features were sectioned to disclose methods and details of construction.

Supra-surface Investigations

Some historic structures are still standing in the project area and warranted special consideration. Two extant houses, 4ILK66 and 41MC175, were measured, photographed, and floor plans drawn. Site $41 \mathrm{MC} 17$ has an extant chimney of sandstone block masonry. Stone chimneys were probably common in the project area. Most sites were marked by mounds of sandstone blocks and upon close examination have chimney foundations associated. To fully document these features above ground, considerable brush clearing usually had to be done. The project area has heavy brush; this has occurred since the original Yarbrough Bend settlement period and is primarily the result of grazing practices. In some cases, a relatively thin layer of dead vegetation and foliage masked features and was raked up or swept from the ground surface. All exposed artifacts and architecture were then recorded. As each site is slightly different, field techniques were used in various combinations. 


\section{LABORATORY ACTIVITIES}

The temporal placement of sites is of paramount importance and it was toward this end that the bulk of lab activity was directed. Major activities are listed below:

1. Identify and tally (by lot) all nail types to gain clues as to the specific details and possible time period of construction of each site, using a nail typology developed and used by Fontana and Greenleaf (1962).

2. Identify and date all metal containers (tin cans) by the chronology of manufacturing processes. Various types of cans might also help determine the economic function of the site and its occupants.

3. Identify and photograph all ceramics with maker's marks. Manufacturers of English ceramics (which comprises the majority of the assemblage) often had short existences; the identification of a manufacturer can therefore help to indicate the time period of manufacture and hence of earliest possible occupation.

4. Classify all ceramics by material type. Some types have restricted time occurrence and so are temporally definitive. Some types were more costly and can serve as an index of socio-economic status.

5. Identify and tabulate personal household items such as toys, clothing and toiletry remains; such items are often age and/or sex specific.

6. Identify all machinery parts (cast or wrought metal); their function is indicative of economic activity.

7. Classify and count glass sherds, evaluate intra-site and inter-site distributions. Glass is of two types, windowpane, and container. Window glass indicates the presence of architecture and possibly economic affluence. Shapes of glass containers are sometimes diagnostic of contents and may give clues to site function or social stratification. Such items as perfume bottles may indicate sex; historic census records might be matched to such archeological data. Manufacturing techniques of bottles are also temporally diagnostic and can be determined.

Here we can note that both population and agricultural censuses have occupational information. Some persons were called "cowboys," 
some "shepherds," some "share croppers." Historically we have conceptions of social status and economic affluence associated with certain occupations. These conceptions may or may not be correct.. Lab analyses may help provide data which will serve as a gauge of the accuracy of these conceptions. 


\section{ARTIFACT DESCRIPTION AND CLASSIFICATION}

The previous work on artifacts from the Choke Canyon sites by Lynn, Fox and O'Malley (1977) was used as a model for artifact classes where possible to allow for comparability between studies, but some modifications were made to meet the needs of this project. Artifacts were cleaned and catalogued and then segregated into genera1 categories of material, e.g., ceramic, glass, metal. Where possible, analytical categories were determined by some function that could be diagnostic of time period. Most materials were subdivided into these use categories, the balance into descriptive categories. Table 6 outlines the artifact classification and Table 7 lists the artifact inventory.

Ceramic

The most numerous artifacts are ceramic. There are three major groups of ceramics present: earthenware, stoneware, and porcelain. Some ceramic specimens were difficult to classify within these types. Each of these categories was subdivided further, based upon observed différences in paste, glaze, decoration, manufacture, and vessel shape and/or function. Only a few sherds displayed maker's marks (Fig. $6, h-j$ ).

\section{Earthenware}

White paste, clear glaze

This class of artifacts is of two types, decorated and undecorated. The undecorated sherds are probably the most frequently found artifacts in the entire assemblage with the possible exception of square cut nails. The volume of undecorated earthenware is reflective of a preference by the 19 th century inhabitants for such wares probably by default (economic restrictions).

The decorated wares are of two main types: 1) those with decorations applied to the surface and 2) those with decorations molded in the paste. These wares are made with a raised design which is accentuated by the glaze having a slight green tint flowing in differential thickness around the raised design making the design visible (Fig. 6, p). These embossed designs are restricted to the rims of vessels (mainly plates) and represent a style of decoration popular mainly through the last half of the 19th century. The balance of the decorated white paste wares are colored designs applied to the vessel by various techniques. The following descriptions pertain to each decorated (non-embossed) ware type, some of which are semidiagnostic of particular time periods and can be used as chronological indicators. 
Blue transfer printed ware

The most abundant decorated ware type, this has various floral, geometric, and scenic designs in blue on a white background (Fig. 6, n). The design is put on vessels from a master copper plate. The copper plate is embossed with the design and is dressed with a thin coat of linseed oil. The excess oil is wiped off leaving the embossed or imprinted design concavities filled with oil. This oil pattern is then picked up with a paper sheet by pressing it against the plate and then against the vessel. This process effectively and quickly transfers the design from the copper plate to the vessel. The still wet oil droplets on the vessel are then carefully dusted with powdered pigment which sticks to the oil areas. Firing of the vessel then fixes the design permanently to the vessel. The designs are typically composed of multiple stipples, many of which fuse (Godden 1964:113).

Variations of wares were created by firing in a chlorine kiln atmosphere (flown blue), using purple pigments (purple transfer printed ware), or using black pigments (no examples found).

The transfer print technique was developed in the $1750 \mathrm{~s}$ but was used mainly on porcelain until the early 1800s. Between the years 1800 and 1825 over 50\% of all English earthenware produced was decorated with this underglaze blue. During the first half of the 19 th century, America was a primary market for English potteries. Blue transfer printed ware is still manufactured today.

\section{Flown blue transfer printed}

Similar to regular blue transfer printed ware, flown blue is manufactured the same way except for the final firing. The firing atmosphere has chlorine (Godden 1964). The visible difference is in the sharpness of the colored image (Fig. 6, k). The chlorine atmosphere causes the blue coloring to diffuse into the covering glaze and on the vessel paste, making the image fuzzy or blurred. The exact temporal span of the ware is not known but is assumed to be contemporary with regular blue transfer printed ware (late 18th century to present).

\section{Purple transfer printed}

This is thought to be the same as the blue transfer printed ware, only the color being different (Fig. 6, 1).

\section{Polychrome transfer printed ware}

Only one example of this ware was recovered, being a transfer printed butterfly design of purple, yellow and blue. 
TABLE 6. ARTIFACT CLASSIFICATION OUTLINE.

I. Ceramic

A. Earthenware

1. white paste

a. clear glaze

(1) undecorated

(2) decorated

a. embossed

b. blue transfer-printed

c. flown blue transfer-printed

d. purple transfer-printed

e. polychrome transfer-printed

f. lined

g. feathered edge

h. sponged

$i$. hand painted floral

j. mocha

k. unclassified

(3) maker marked

b. colored glaze

(1) solid colored

(2) embossed brown glazed

(3) maker marked

2. colored paste

a. clear glazed

b. tin-enameled ware

B. Stoneware

1. Albany glaze interior

a. Albany glazed exterior

b. Bristol glaze exterior

c. gray or tan salt glazed exterior

d. gold glazed exterior

2. Bristol glazed interior

a. Bristol glazed exterior

b. yellow glazed exterior, red paste

3. alkaline glazed interior

a. clear glazed exterior

b. red paste

4. unglazed red paste

5. orange glazed interior and salt glazed exterior

6. buff-orange slipped

7. salt glazed rims and handles

8. green alkaline glazed interior and exterior

9. white glazed with blue speckles

C. Brick

D. Porcelain

E. Miscellaneous 
TABLE 6. (continued)

II. Glass
A. Clear
1. botties
2. jars
3. special
B. Aqua
1. bottles
2. window
C. Amber
1. bottle
D. Green
1. bottle
E. Miscellaneous

III. Meta 1

A. Farming and ranching implements

B. Construction materials

C. Household items

1. general house and garden

2. kitchen implements

D. Personal items

E. Cast metal

F. Gun parts and ammunition

IV. Other Objects

V. Prehistoric Artifacts 
TABLE 7. ARTIFACT INVENTORY。

$\begin{array}{lllllllllllllll}\text { 41LK66 } & \text { MC15 } & 17 & 46 & 72 & 74 & 91 & 166 & 168 & 175 & 185 & 192 & 193 & 194 & 195\end{array}$

\section{CERAMIC}

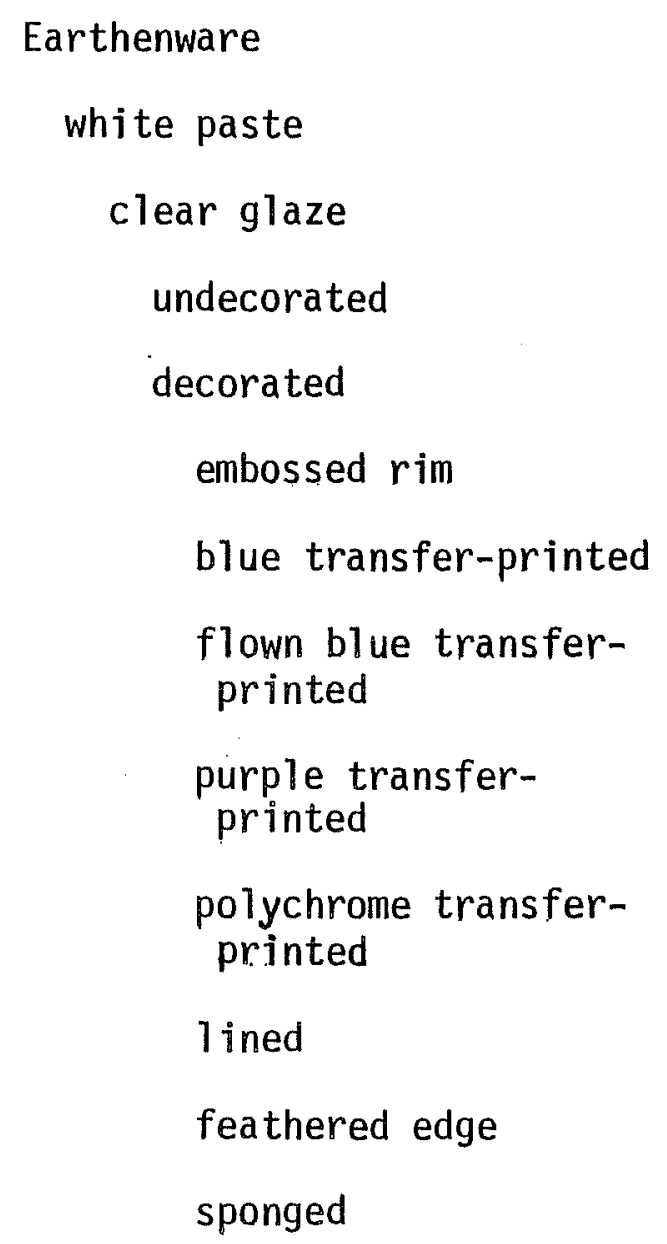

\begin{tabular}{|c|c|c|c|c|c|c|c|c|c|c|c|c|c|}
\hline 59 & 49 & 65 & 42 & 14 & 49 & 22 & 18 & 15 & 15 & 35 & 54 & 8 & 7 \\
\hline & 1 & 1 & & 2 & 12 & & & & & 1 & 3 & 2 & \\
\hline \multirow[t]{4}{*}{1} & 4 & & & & 2 & & & & & & & & \\
\hline & 2 & & 1 & & 15 & & & & & & 1 & & \\
\hline & & & & & & & & & & 1 & 9 & & \\
\hline & & & & & 2 & & & & & & 4 & 7 & 1 \\
\hline \multirow[t]{3}{*}{2} & 2 & 1 & & & 5 & & & & & & 1 & & \\
\hline & 2 & & & & 4 & & & & & & 5 & & \\
\hline & 8 & & & & 7 & & & & 2 & & 1 & & \\
\hline
\end{tabular}


TABLE 7. (continued)

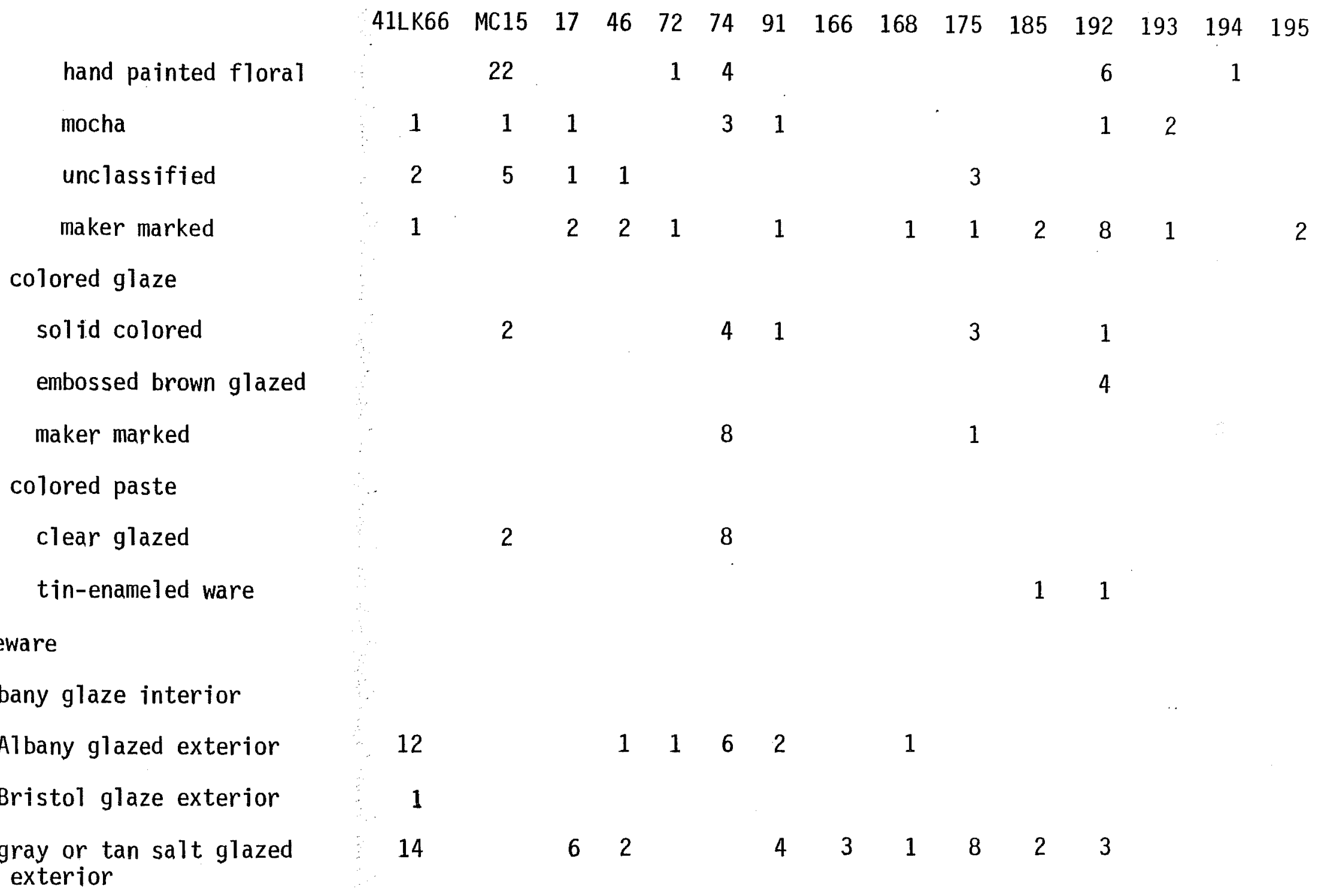




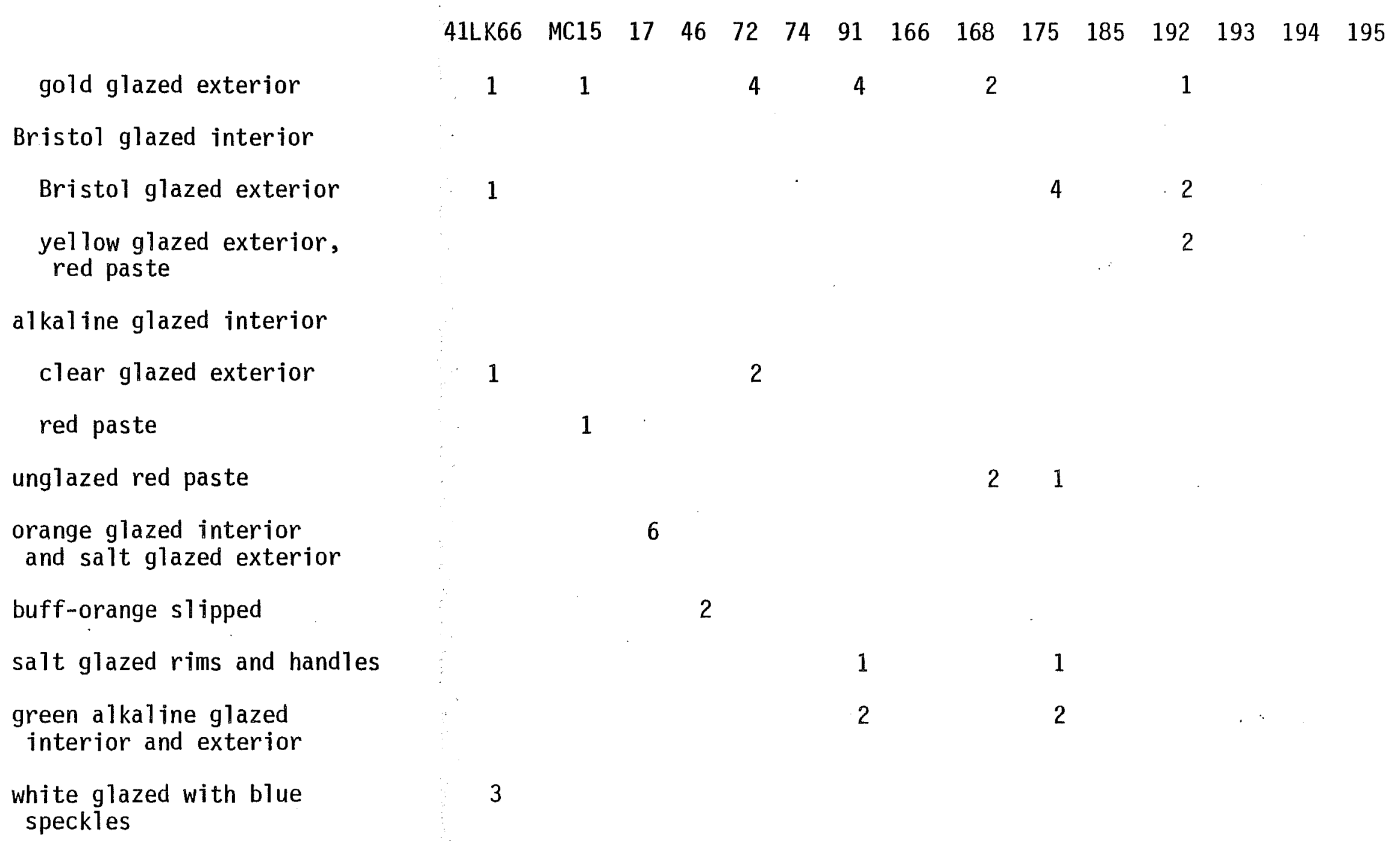


TABLE 7. (continued)

$\begin{array}{lllllllllllllll}\text { 41LK66 } & \text { MC15 } & 17 & 46 & 72 & 74 & 91 & 166 & 168 & 175 & 185 & 192 & 193 & 194 & 195\end{array}$

Brick
Porcelain
door knob
Miscellaneous
Glass
clear
bottle
complete, machine
made
rim
rim, machine made
rim, applied lip
rim, applied lip,
bead finish
rim, applied lip,
extract finish
base

1

6

1

2

7

6

2

$\begin{array}{llllll}4 & 7 & & 1 & 4 \\ 3 & & 1 & & \\ & & & & 1 \\ & & & & \\ & & & & \end{array}$

8
3

4

$\begin{array}{llllll}4 & 2 & 1 & 8 & 1 & 1\end{array}$


TABLE 7. (continued)

\begin{tabular}{|c|c|c|c|c|c|c|c|c|c|c|c|c|c|c|c|}
\hline & $41 L K 66$ & MC15 & 17 & 46 & 72 & 74 & 91 & 166 & 168 & 175 & 185 & 192 & 193 & 194 & 195 \\
\hline base, machine made & 5 & & & 1 & & & & & & 3 & & & & & \\
\hline body, cylindrical & 39 & 2 & 8 & 9 & 3 & 24 & 9 & 1 & 1 & 5 & 2 & 8 & 3 & 1 & \\
\hline body, panel & 9 & & 3 & 3 & 2 & 3 & 1 & & & 5 & & 1 & & 1 & \\
\hline $\begin{array}{l}\text { body, embossed } \\
\text { jar }\end{array}$ & 9 & & & & & 6 & 2 & 7 & 2 & 9 & & 3 & & & 1 \\
\hline $\begin{array}{c}\text { rim } \\
\text { special }\end{array}$ & 5 & & 1 & & & 1 & & 3 & & 3 & & & 1 & & 1 \\
\hline goblet base & & & & & & & & & & 1 & & & & & \\
\hline $\begin{array}{l}\text { mug handle } \\
\text { aqua }\end{array}$ & & & & & & & & & & 1 & & & . & & \\
\hline bottle & & & & & & & & & & & & & & & \\
\hline $\begin{array}{l}\text { complete, cup mold, } \\
\text { applied } 1 \text { ip }\end{array}$ & & & & & & & & & & & & 1 & & & \\
\hline rim, machine made & 2 & & & & & & & & & & & & & & \\
\hline rim, applied lip & & & & & 2 & & & & & & & & & & \\
\hline $\begin{array}{l}\text { rim, applied lip, } \\
\text { oil finish }\end{array}$ & 1 & & & & & & & & & & & & & & \\
\hline
\end{tabular}


TABLE 7. (continued)

rim, applied 1ip, extract finish

rim, applied lip, champagne finish

rim, applied lip, bead finish

rim

base

base, bottom-hinged mold

body, cylindrical

body, pane1

body, embossed

window

amber

bottle

complete, machine made $\begin{array}{lllllllllllllll}\text { 41LK66 } & \text { MC15 } & 17 & 46 & 72 & 74 & 91 & 166 & 168 & 175 & 185 & 192 & 193 & 194 & 195\end{array}$

2

1

11

$\begin{array}{llll}3 & 1 & 1 & 1\end{array}$

1

$\begin{array}{lll}1 & 1 & 1\end{array}$

24

$\begin{array}{llll}4 & 2 & 5 & 4\end{array}$

4

$\begin{array}{llllllllll}3 & 9 & 11 & 6 & 1 & 2 & 21 & 15 & 3 & 3\end{array}$

93

$\begin{array}{lllllllll}4 & 22 & 2 & 2 & 1 & 1 & 13 & 12 & 3\end{array}$

$241 \quad 13 \quad 8$

$\begin{array}{lll}5 & 1 & 1\end{array}$

$14 \quad 5 \quad 6$ 
snuff

complete, machine made

fragment

fragment, machine made

rim

rim, machine made

rim, applied lip

rim, applied packer finish

rim, applied lip, oil finish

base

base, machine made

base, bottom hinged mold

body, cylindrical $\begin{array}{lllllllllllllll}\text { 41LK66 } & \text { MC15 } & 17 & 46 & 72 & 74 & 91 & 166 & 168 & 175 & 185 & 192 & 193 & 194 & 195\end{array}$
2

3

4

2

1

1

4

1

1

6

1

21

2

1

2

2

4

1

$\begin{array}{lll}2 & 1 & 1\end{array}$

112
132

$\begin{array}{lllllll}6 & 2 & 2 & 3 & 2 & 6 & 6\end{array}$ 
TABLE 7. (continued)

body, panel

body, embossed

\section{green}

bottle

complete, machine made

rim

rim, applied lip

rim, applied 1ip, extract finish

base

base, kickup

body, cylindrical

body, panel

miscellaneous

clear $\begin{array}{lllllllllllllll}41 L K 66 & \text { MC15 } & 17 & 46 & 72 & 74 & 91 & 166 & 168 & 175 & 185 & 192 & 193 & 194 & 195\end{array}$
1. $5 \quad 8 \quad 4$
10

1

1

1

4
1

2

1

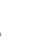

.

4

\begin{tabular}{|c|c|c|c|c|c|c|c|c|c|c|}
\hline & & & 3 & & & & & 1 & & \\
\hline & & & & 1 & & & 1 & 2 & 1 & 1 \\
\hline 9 & 12 & 6 & 26 & 3 & 1 & 2 & 1 & 16 & 3 & \\
\hline 1 & 1 & & 2 & & & & & 4 & 1 & \\
\hline
\end{tabular}


TABLE 7. (continued)

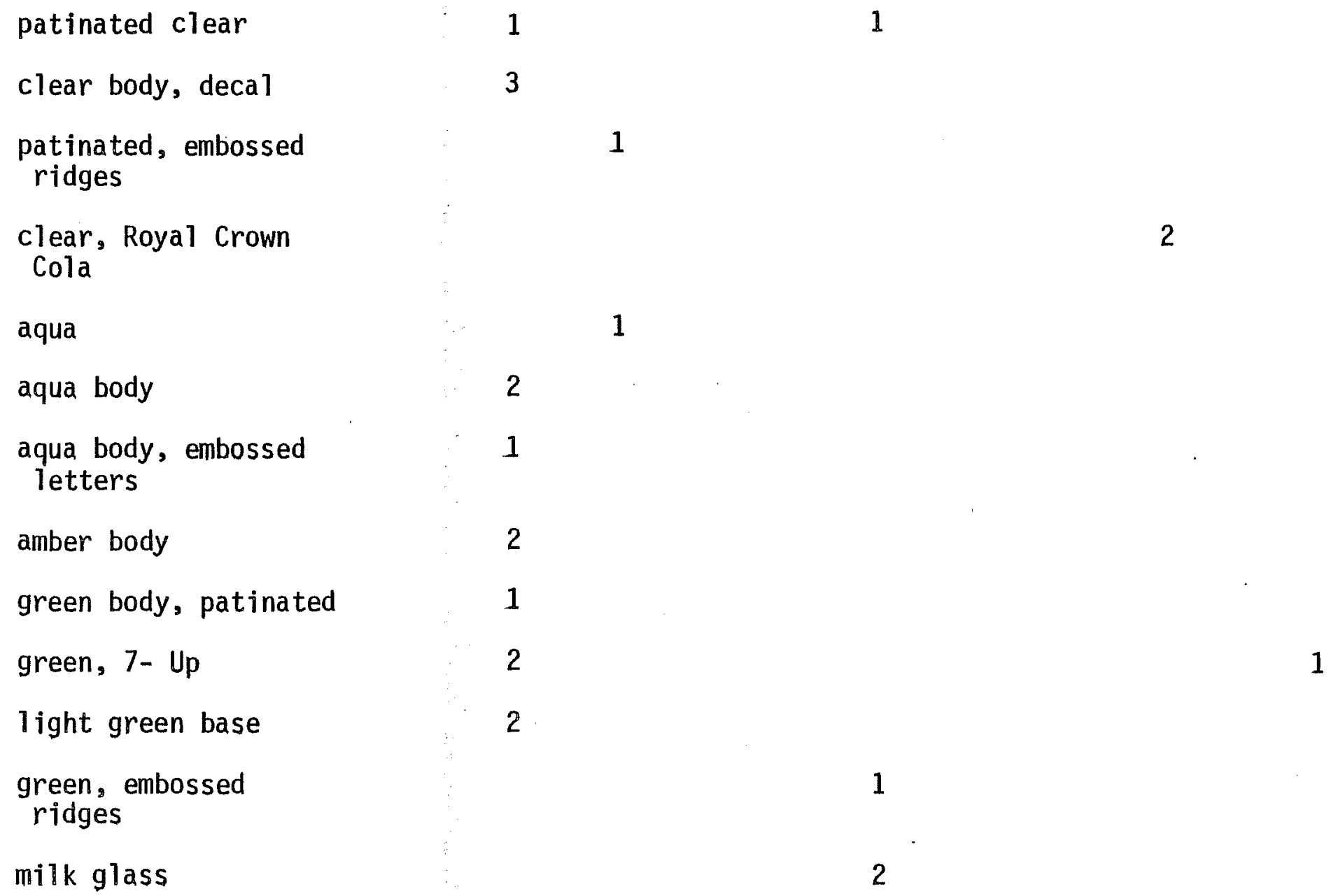

2

green, 7- Up 2

light green base 2

2

1 
TABLE 7. (continued)

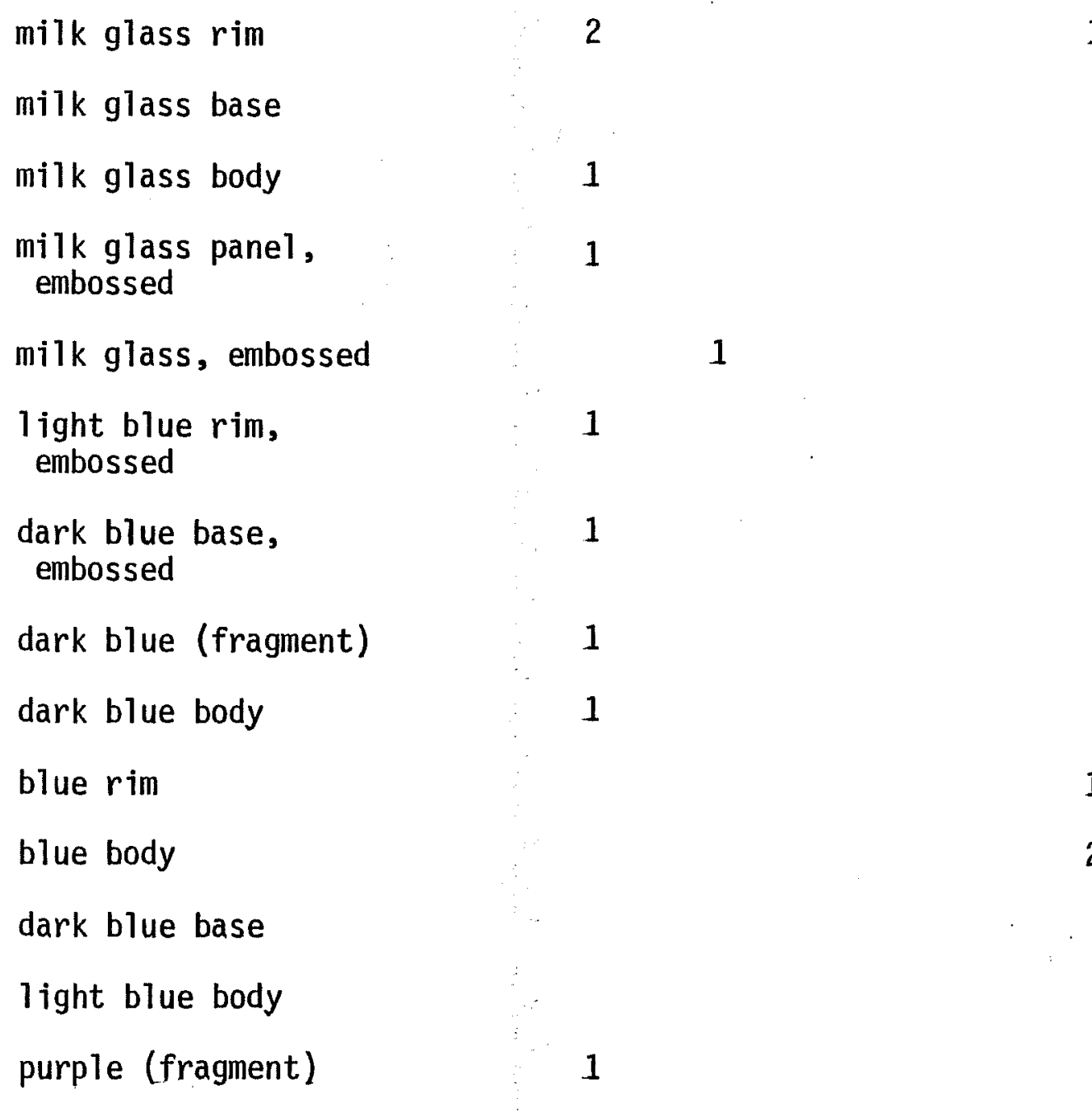

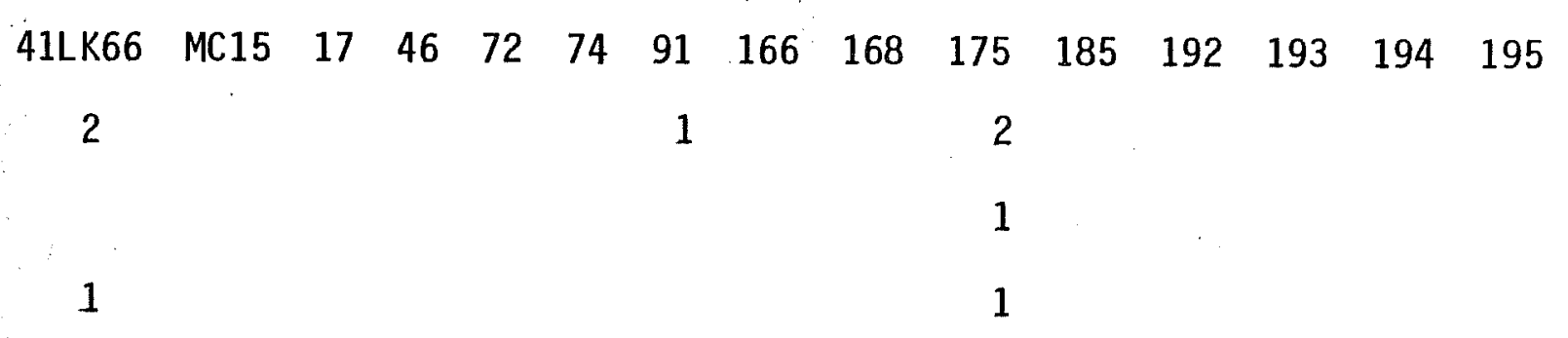

1

2

2 
TABLE 7. (continued)

$\begin{array}{lllllllllllllll}41 \mathrm{LK} 66 & \text { MC15 } & 17 & 46 & 72 & 74 & 91 & 166 & 168 & 175 & 185 & 192 & 193 & 194 & 195\end{array}$

red body

red rim

dark red body

yellow

blue and white marble

clear and white marble

\section{Metal}

\section{farming and ranching}

implements

horseshoe

ring

tub handle

wagon hardware

strapping

galyanjzed strapping

flat wire
1

1

1

1

1

1

1

1

1

1

3

2

1

1

2

1

2

$\begin{array}{lll}1 & 3 & 2\end{array}$

2 
TABLE 7. (continued)

$\begin{array}{lllllllllllllll}41 \text { LK66 } & \text { MC15 } & 17 & 46 & 72 & 74 & 91 & 166 & 168 & 175 & 185 & 192 & 193 & 194 & 195\end{array}$

baling wire

5

heavy wire

2

$\begin{array}{llll}1 & 1 & 2 & 3\end{array}$

2

galvanized wire

2

railroad-type spike

1

brass fitting

1

roller

1

hammer wedge

1

wrought spike

1

nuts and bolts, miscellaneous

chain link

wrought material

13

2

wrought anchor device

31

wrought hook and eye

2

anchoring device

copper tubing and fitting 
bolt and washer

rivet

buckle

buckle with leather strap

cha in and ring

bicycle chain

decorative hinge

"6" strap hinge

wing nut

washer

gas cap

spark plug

heavy machinery chain

slotted eye lag bolt

grommet
2

2
2

1

1

1

1

2

1

3

1

1

1

1

11 
TABLE 7. (continued)

$\begin{array}{lllllllllllllll}\text { 41LK66 } & \text { MC15 } & 17 & 46 & 72 & 74 & 91 & 166 & 168 & 175 & 185 & 192 & 193 & 194 & 195\end{array}$

threaded rod

harness buckle

unidentified

construction materials

square cut nails

wire nails

wood screws

tacks

masonry screw nails

staples

household items

general house and garden

clock part

mop head

door plate

key
1

$2 \quad \begin{array}{llll}1 & & 1 \\ 2 & 1 & 1\end{array}$

$\begin{array}{rrrrrrrrrrrrrr}126 & 75 & 174 & 24 & 37 & 20 & 2 & 3 & 5 & 38 & 39 & 9 & 3 & 1 \\ 164 & 1 & 1 & 1 & 2 & 11 & & & 24 & 2 & 2 & & & \\ 2 & & & & & 1 & & & 2 & & & & \\ 5 & & & & & & & & & & & & \\ 3 & & & & & & & & & & & & & \\ 1 & & & & & & & & & & & & & \end{array}$

1

1

1

2 


\begin{tabular}{|c|c|c|c|c|c|c|c|c|c|c|c|c|c|}
\hline & $41 L K 66$ & MC15 & 17 & 46 & 72 & 74 & 91 & 166 & 168 & 175 & 185 & 192193 & 194 \\
\hline battery post & 1 & & & & & & 1 & & & 2 & & & \\
\hline window screen fragments & 3 & & & & & & & & & & & & \\
\hline lantern base & 1 & & & & & & & & & & & & \\
\hline $\begin{array}{l}\text { decorative copper or } \\
\text { brass }\end{array}$ & 1 & & & & & & & & & & & & \\
\hline coat hook & & & & & & 1 & & & & & & & \\
\hline furniture hardware & & & & & & & 1 & & & & & & \\
\hline hoe & & & & & & & & & & 1 & & & \\
\hline heayy spring & & & & & & & & & & 1 & & & \\
\hline file & & & & & & & & & & 1 & & & \\
\hline suitcase hinge & & & & & & & & & & 1 & & & \\
\hline keyhole plate & & & & & & & & & & 1 & & & \\
\hline fish hook & & & & & & & & & & & & 1 & \\
\hline upholstery tack & & $\therefore$ & & & & & & & & & & 1 & \\
\hline lamp part & & & & & & & & & & & & 1 & \\
\hline bell clapper assembly & & & & & & & & & & & & 1 & \\
\hline
\end{tabular}


TABLE 7. (continued)

$\begin{array}{lllllllllllllll}\text { 41LK66 } & \text { MC15 } & 17 & 46 & 72 & 74 & 91 & 166 & 168 & 175 & 185 & 192 & 193 & 194 & 195\end{array}$

chamber pot cover

foil packet

1

tin cans-identifiable

2

tin can fragments

1

$\begin{array}{lll}1 & 1 & 1\end{array}$

$\begin{array}{lll}2 & 5 & 1\end{array}$

tin can lids

$\begin{array}{lllll}11 & 3 & 2 & 2 & 11\end{array}$

1

$19 \quad 9$

1

1

flat tin container

1

jar 1 id

1

Crown bottle caps

22

2

1

foil bottle cap liners

2

Pearl bottle caps

2

Teem bottle caps

1

non-ferrous white metal

24

tubular copper

unidentified

3

1

$\begin{array}{lll}1 & 1 & 1\end{array}$ 
kitchen implements

coffee pot

coffee or tea pot lid

tea pot spout

metal plate

pot

decorative spoon

knife handle

smal1 pan

serving spoon

ice tray divider

coffee percolator part

can/bottle opener

butcher knife blade

table spoon

stove pipe elbow
1

1

1

1

1

1

1
1

1

1

1

2

1

1 
TABLE 7. (continued)

$\begin{array}{lllllllllllllll}\text { 41LK66 } & \text { MC15 } & 17 & 46 & 72 & 74 & 91 & 166 & 168 & 175 & 185 & 192 & 193 & 194 & 195\end{array}$

fork handle

pickle fork handle

1

utensil handle

scissors handle

personal items

clothing rivet

2

11

1

toy gun

1

pencil lead

1

buckle

11

3

1

button

1

1

1

gold flaked bead

1

needle

2

1

3

11

slate blackboard

knife blade

snap

1

S-hook 
TABLE 7. (continued)

$\begin{array}{lllllllllllllll}\text { 41LK66 } & \text { MC15 } & 17 & 46 & 72 & 74 & 91 & 166 & 168 & 175 & 185 & 192 & 193 & 194 & 195\end{array}$

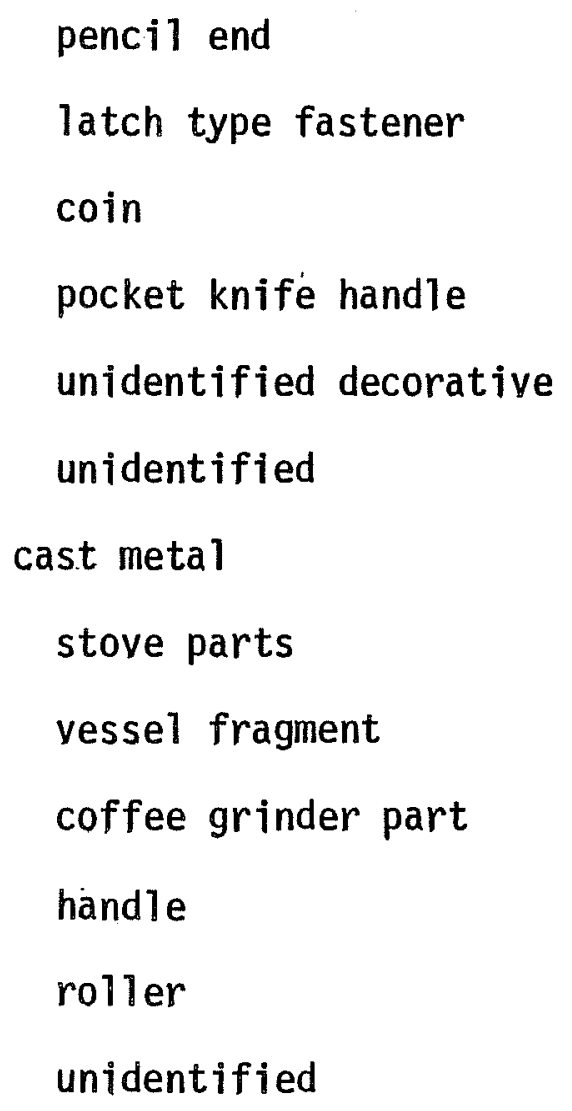

\section{4}

1

$\mathbb{1}$

1

1

2
1

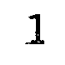

$\begin{array}{llll}1 & 2 & 2 & 1\end{array}$

1

1

gun parts and ammunition

tumbler 
TABLE 7. (continued)

$\begin{array}{lllllllllllllll}\text { 41LK66 } & \text { MC15 } & 17 & 46 & 72 & 74 & 91 & 166 & 168 & 175 & 185 & 192 & 193 & 194 & 195\end{array}$

trigger assembly

1

lead balls and bullets

$.36 \mathrm{cal}$ (?)

.44 cal (?)

2

lead ball

1

fragments

unidentifiable

1

1

21

percussion cap

cartridges

shotgun shel1

11

$.22 \mathrm{cal}$

1

$.45 \mathrm{cal}$

1

.16 gauge shotgun

.12 gauge shotgun

1

.44 Henry flat

3

1

1

$1 \stackrel{⿱ ⺊ 口}{上}$

.44 short 


.44 cal
$.44-40$
.41 short
.45 Colt
$.30-.30$
.38
.32
.20 gauge shotgun
7 mm
$.30-.06$
.222

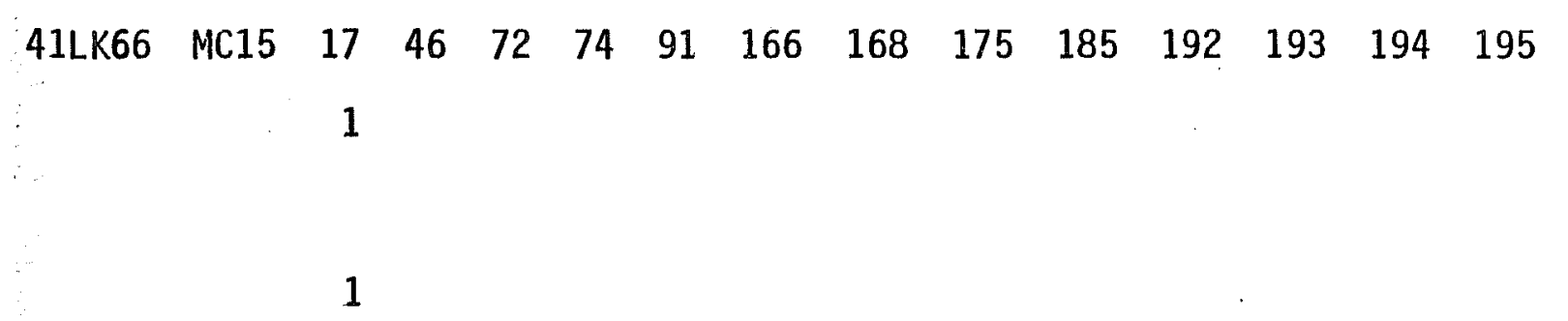


TABLE 7. (continued)

$\begin{array}{lllllllllllllll}\text { 41LK66 } & \text { MC15 } & 17 & 46 & 72 & 74 & 91 & 166 & 168 & 175 & 185 & 192 & 193 & 194 & 195\end{array}$

button, black plastic

toy wheels

bottle caps

dart shaft

syringe

bead

unidentified

wall lpaper (fragments)

wood (fragments)

snail

she11

bone

Prehistoric artifacts

chipping debris

pottery

1

2

1

1

1

1

4

5

3

$\begin{array}{lllll}2 & 68 & 72 & 10 & 6\end{array}$

32

$\begin{array}{llllll}33 & 47 & 150 & 1 & 3 & 16\end{array}$

$x \quad x$

$50 \quad 1001601$

$4 \quad 61$

1
$103 \quad 1$

1 
TABLE 7. (continued)

$\begin{array}{lllllllllllllll}\text { 41LK66 } & \text { MC15 } & 17 & 46 & 72 & 74 & 91 & 166 & 168 & 175 & 185 & 192 & 193 & 194 & 195\end{array}$

finished artifacts

point-Tortugas

point-Bulverde.

point-Catan

point-Scalllorn

point-thin triangular

lanceolate stemmed dart point

thinned biface

triangular unifacial scraper

gouge

fragment
1

$1 \quad 1$

1

1

1

1

11

1

1

1

2

2 
Lined

This type has colored lines near the lip on rim sherds. The colors are varied, as are the widths. The lines occur mostly on cups. This type encompasses the entirety of the chronology chart from the 18th century to the present, and therefore cannot be used as a distinct time indicator. Lines are mostly of dark brown color near the lip of the vessel rim and often are in an interior-exterior set (Fig. 6, d). One lined cup rim sherd is decorated with a floral sponged design in green underglaze. Two sherds are gilded in a single band.

Feathered edge

The decoration motif of this type is a blue band on the edge of plate rims with the interior edge of the blue band painted to a "feathered edge" (Fig. 6, a, c). The surface treatment of the paste is usually molded, with linear or curvilinear indentations oriented perpendicular to the interior face of the plate rim. Some plates are not molded. All rims are smooth. This type ware was apparently manufactured in England during the first three-fourths of the 19 th century and was a popular ware in Texas during the mid-19th century (Davis and Corbin 1967).

Sponged

Sponged ware has a decoration application using a stamp made of sponge stem (Godden 1964:111). A design is carved in the cross-cut end section of a sponge stem or root, and after being dipped in the color solution is applied repeatedly to the vessel surface (Fig. 6, m). One specimen (Fig. 6, o) is a cup stamped with semi-floral patterns of red (lower) and green (upper) colors which are fairly detailed.

Hand painted floral design

This ware is characterized by colored flower blossoms, leaves, stems, and related plant-like decorative motifs in underglaze colorings hand painted onto the vessel (Fig. 6, e-g). The chronological position of this ware cannot be closely delineated as it was manufactured widely throughout the 19 th century.

\section{Mocha}

This ware type is the same as banded ware (Lynn, Fox and O'Malley 1977:187). Mocha ware has a manufacturing time range of 1799 to the present day (Godden 1964:109). Typical mocha ware often contains tree-like patterns but none was present in this assemblage. Colors present include blue and white; blue, gray/green and white; and yellow, white and dark brown. All bands are on exterior surfaces (Fig. 6, b). 
Figure 6. Various Ceramics: earthenware, stoneware and porcelain.

a. feathered edge ware

b. mocha "banded" ware

c. feathered edge ware

d. lined earthenware

e-g. hand painted floral design earthenware

h. earthenware sherd with maker marks, Bridgewood \& Clarke, Burslem, England, 1857-1864

i. earthenware sherd with maker marks, J. W. Pankhurst \& Co., Hanley, England, 1850-1882

j. earthenware sherd with maker marks, Bridgewood \& Clarke, Burslem, England, 1857-1864

k. flown blue printed earthenware

1. purple transfer printed earthenware

m. sponged earthenware

n. blue transfer printed earthenware

o. sponged decorated cup with top patterns green and bottom patterns red

p. stoneware larged mouthed vessel

$q-r$. porcelain objects

s. unidentified tubular piece

t. insulator 

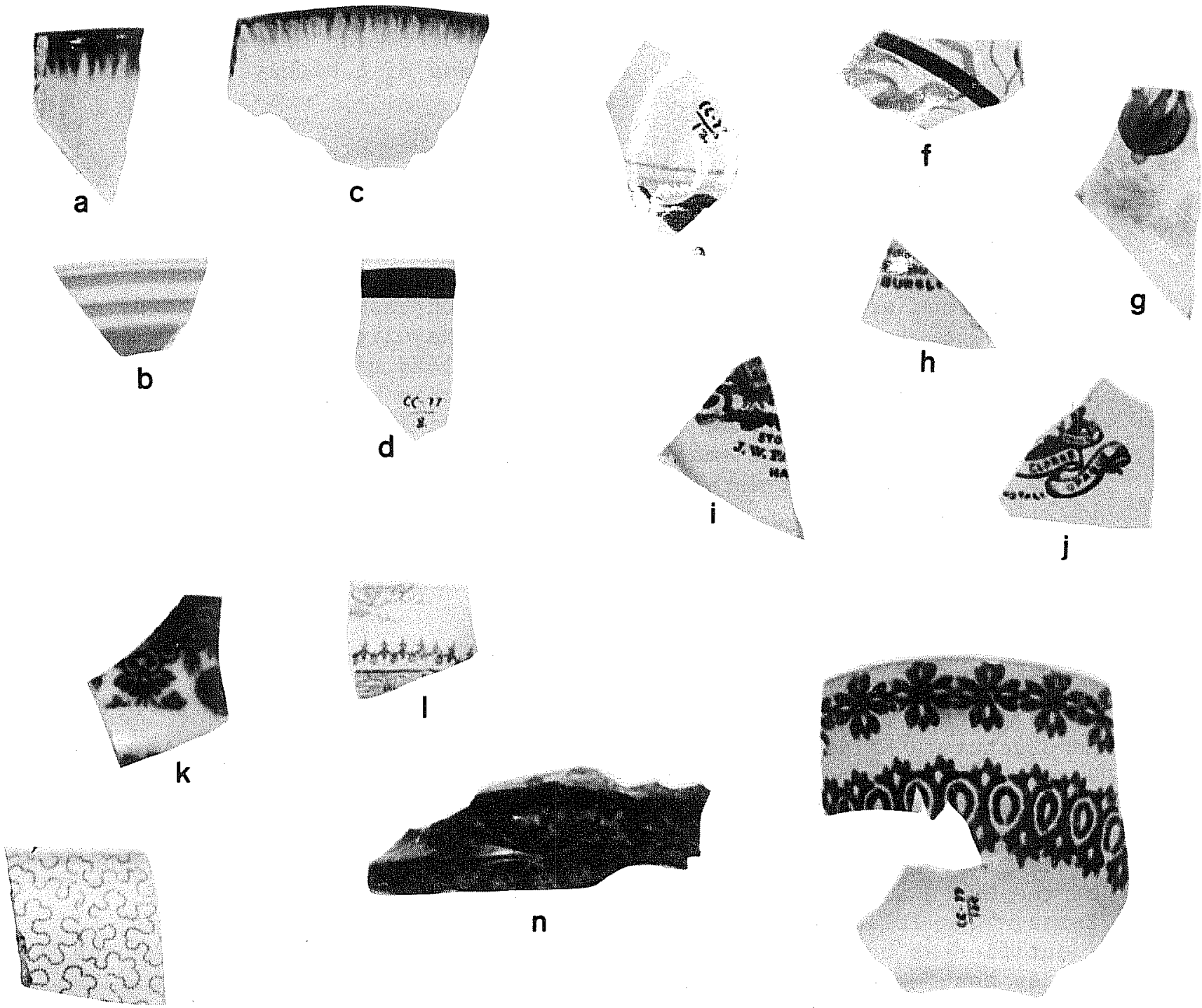

m
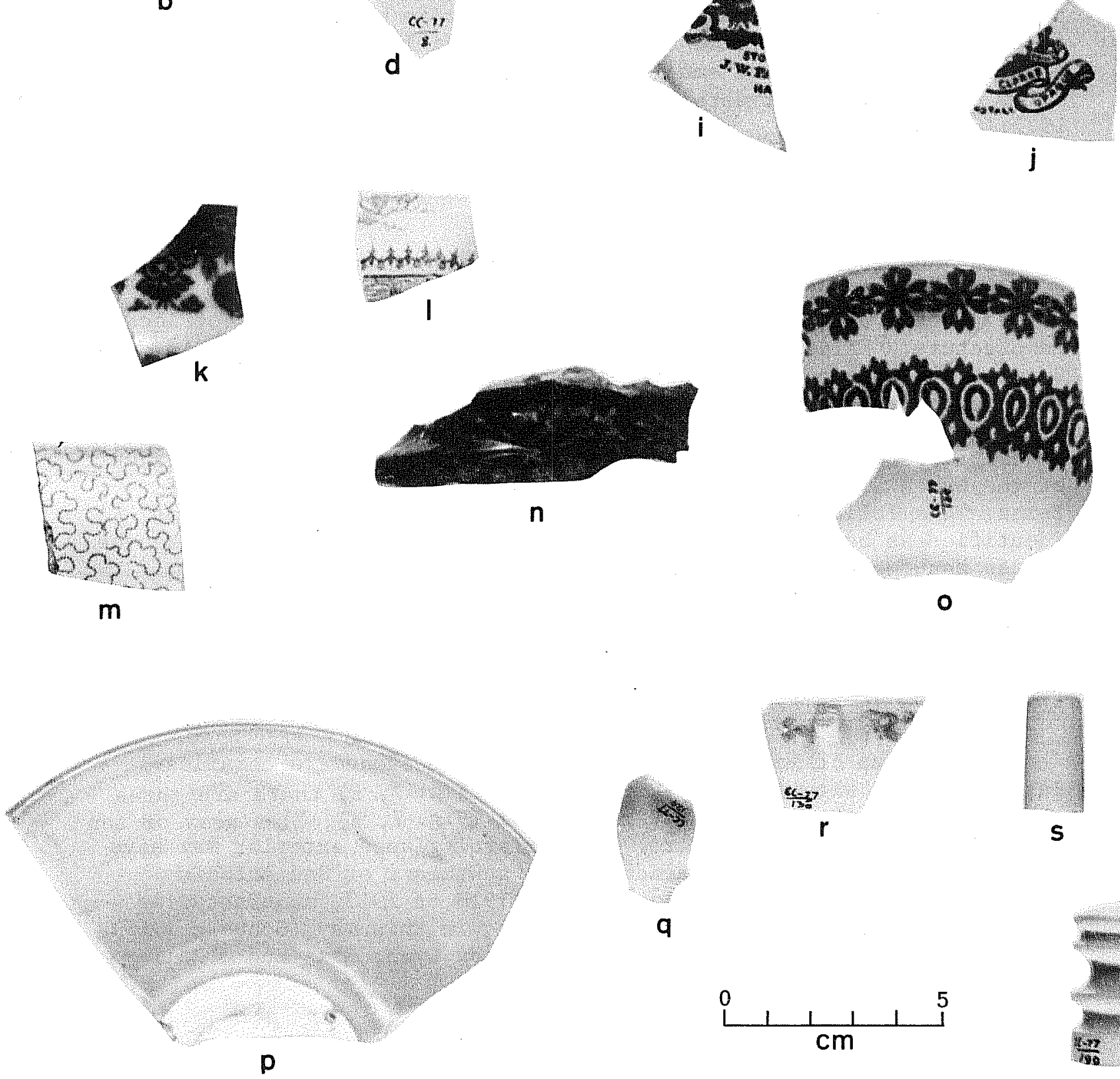

0

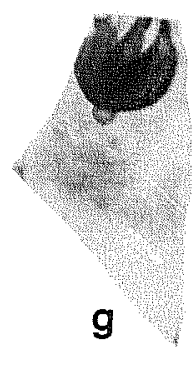


White paste, colored glaze

The class of artifacts is of 2 sub-groups: solid colored and embossed brown glazed. The age of both these types is unknown. The solid colored glazed wares have an evenly covered monochromatic glaze. The brown glazed pieces are all sherds of a highly decorated (embossed) vessel or perhaps of figurines.

\section{Colored paste earthenware}

Colored paste wares recovered were of two types, clear glazed and tin enameled ware. Several small sherds with clear glaze were recovered and are of an unknown type. The tin enameled ware sherd from $41 \mathrm{MC} 185$ is probably Mexican majolica. Majolica is characterized by an opaque white enamel of tin oxide in a lead glaze and a soft paste body (Goggin 1968:3). It dates from quite early (1650) but is made up to the present time and is datable mainly by design components and motifs. None of the small pieces recovered is complete enough to allow such dating (for detailed discussion see Lynn, Fox and O'Malley 1977:188-189, 216).

\section{Stoneware}

The numerous types of this class of ceramics are designated by various colors, types, and combinations of glazes and pastes. The manufacturers of this ware are unknown but some are possibly of local manufacture. Kilns are known to have been in operation at San Antonio, Seguin, and Texana, Texas during the mid to late 19 th century, and some tentative matches are proposed. Comparative specimens from these kilns were not available at the time of this analysis, but written descriptions indicate some of the wares may be the same. The balance of the wares are probably from manufacturers outside the state of Texas. The following glazes labeled as Bristol and Albany are not identified as being manufactured in Bristol or Albany but are like the glazes manufactured there. Albany is a dark brown, highly glossy semi-opaque glaze and Bristol is a glossy white to cream colored opaque glaze.

\section{Albany glaze interior}

This group of wares is the largest of the stoneware ceramics. Besides sherds with Albany glaze exterior (Fig. 7, a) there are three other types of exterior glaze, 1) Bristol (Fig. 7, b), 2) a gray or tan salt glaze and 3) a gold glaze. The Bristol glazed exterior may have been manufactured at the Elmendorf kiln southeast of San Antonio which was in operation between 1885 and 1916 or 1917, manufacturing crockery vessels of local clays and glazed in this way (Schuetz 1969: 23-24). The previous work at these sites by Lynn, Fox and O'Malley 

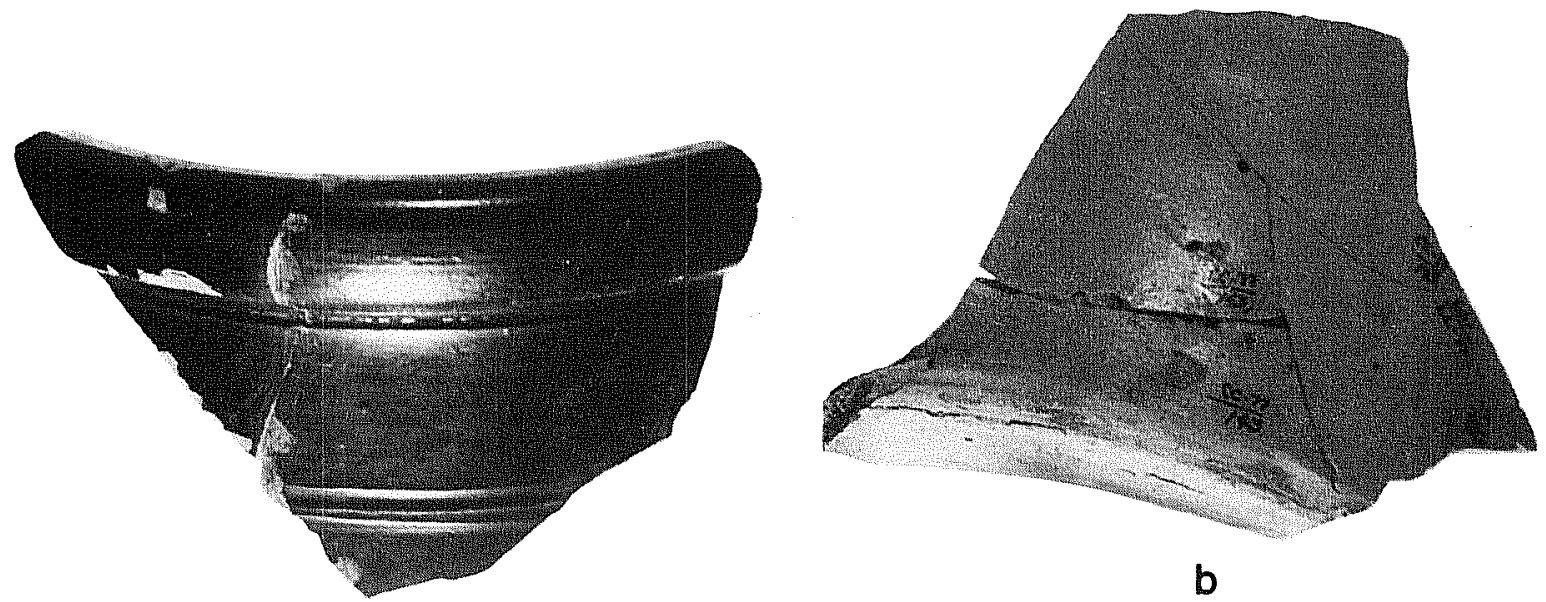

b

\section{a}
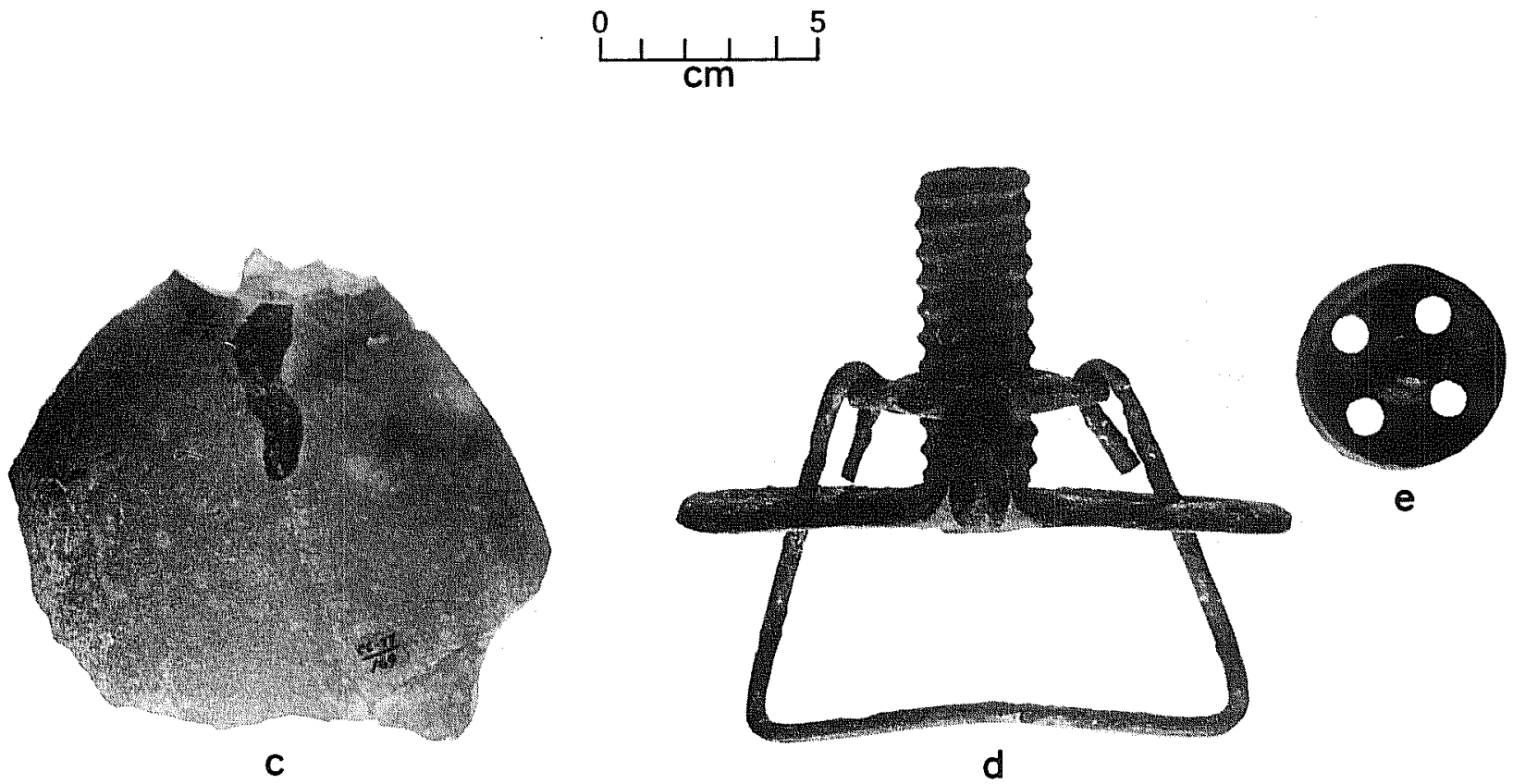

Figure 7. Stoneware cerames and Metal Artefacts. a, stoneware large mouthed vessel rim sherd, Albany glazed interior and exterior; b, stoneware vessel, base sherd, Albany glazed interior, Bristol glazed exterior; c, stoneware, jug body sherd with olive green salt glazed exterior and orange glazed interior; d-e, mop head fragments. 
(1977:194) recovered one specimen of this type from site 41MC166 which was manufactured by the Western Stoneware Company of Monmouth, Illinois, after the turn of the century. No recovered specimens have maker marks.

The gray or tan salt glazed exterior sherds are similar to those recovered in 1976 with various gray to tan colors, the shade partly dependent on the color of the sherd paste caused by the kiln firing environment. The color configuration of light colored glaze on the lower exterior body of jugs and jars seems to be fairly common. Manufacturers are unknown, as are the dates of manufacture.

Specimens with the gold glazed exterior may have been turned this color by clay iron content used in making the glaze mix. No age or manufacturer information is known.

The last type of sherd within this stoneware class is that with Albany glaze on both surfaces. Only a few sherds were recovered in this study which had both Albany and Bristol glaze on the exterior surface. The previously mentioned vessel made by the Western Stoneware Company was covered in Bristol glaze on the jug body exterior and Albany glaze on the neck, mouth, handle and interior of the jug in a style popular in the 19 th century. Some small sherds in this group are from the upper parts of jugs (Fig. 8, g), but some are straight sided vessel walls, and one specimen included the rim of a large open jar (Fig. 7, a). Except for possible jugs, no known locally manufactured wares have Albany glazed exteriors.

\section{Bristol glazed interiors}

A few sherds were recovered with Bristol glaze on the interior and the exterior. These are apparently from large open top jars and similar to wares made at the Elmendorf kiln. Another variation is represented by several sherds with a yellow exterior glaze and red paste. These sherds are relatively thin and are portions of smaller containers for liquids such as ink (Fig. 9, a) or ginger beer.

\section{Alkaline glazed interior}

Two types of wares so glazed were analyzed, one with a clear exterior overglaze and one unglazed with red paste. Similar wares were recovered in 1974-76 (Lynn, Fox and $0^{\prime}$ Malley 1977:195) and are generally nondescript, greenish color glazed crockery.

\section{Unglazed red paste}

This ware, known otherwise as "bisque" ware, is generally used for such functions as flooring and roofing and is not generally used for food or fluid storage (the common use of crockery) due to its porosity. Unglazed ware will not contain liquids without seeping 

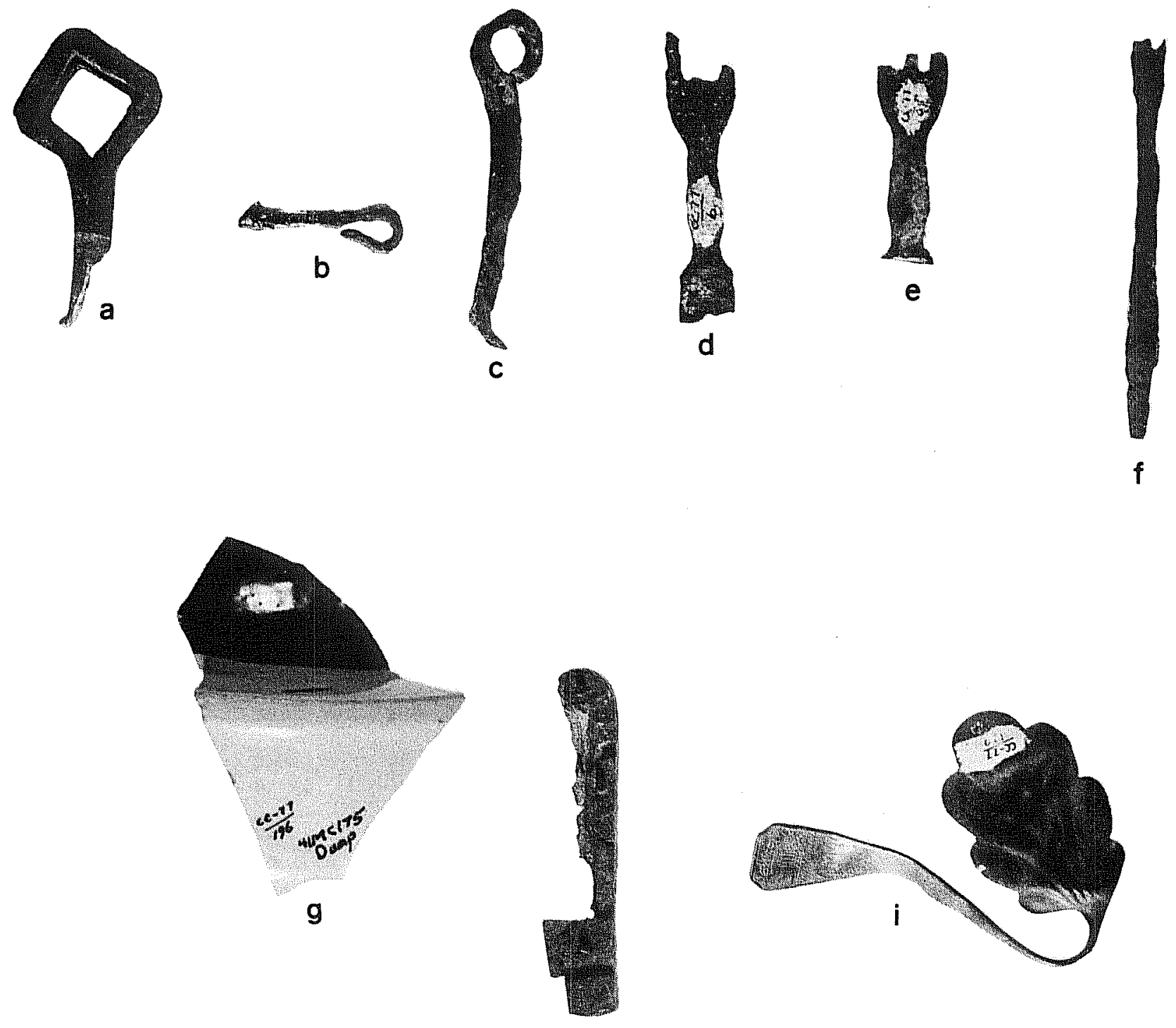

h

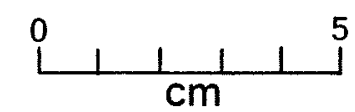

Figure 8. Wrought Metal, Stoneware and Household Artifacts. a-c, wrought metal pieces; d-f, cast iron forks; $g$, upper part of stoneware jug; $h-i$, pocket knife and brass relish spoon. 
and leaking. Kilns at San Juan and Texana both produced unglazed wares (Schuetz 1969:25) but neither is considered to be the actual source for these recovered specimens. The Texana kiln was operated between 1854 and 1865, perhaps too early for the Yarbrough Bend community and too distant. The kiln at San Juan was in operation between 1928 and the 1930 s and may be too late. It was founded by James Richter, "the last working pottery of those German settlers who founded at least half a dozen kilns...near San Antonio" (Schuetz 1969:25). This phrase implies there were numerous other kilns (some unnamed) which were earlier and are candidates for being the origin of many of the project wares.

Orange glazed interior and salt glazed exterior

This ware (Fig. 7, c) has poorly fired orange glaze on the vessel interior and an olive green salt glazed exterior. Exterior glaze has a grainy and mottled surface characteristic of poorly fired salt glaze. The sherd paste is a yellow buff.

\section{Buff-orange slipped}

This unusual ware is identical to that recovered in 1974-76 (Lynn, Fox and O'Malley 1977:195) and is identified by the distinct orange colored interior. The orange color permeates deep into the paste and numerous sand grains are visible through the slip and throughout the paste. One sherd, a base, shows these sherds to be from a flaring-sided bowl; the orange color soaked entirely through to the bottom exterior surface of the vessel. Both recovered sherds are exteriorly glazed with a thin yellow matte surface material.

\section{Salt glazed rims and handles}

Represented by one sherd of each, these vessels are covered with a thin gray salt glaze. Coming from different sites, they are not from the same vessel and there are no other similarly glazed body sherds from this type of vessel.

\section{Green alkaline glazed interior and exterior}

This ware, glazed on both surfaces with a thick even glaze, is a dark olive green on the interior and a lighter yellowish green on the exterior. The interior and exterior glazes are probably the same material but are different colors due to the difference of firing atmosphere in the interior of the jug. 


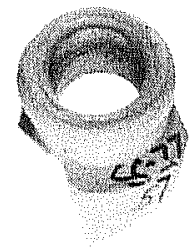

a
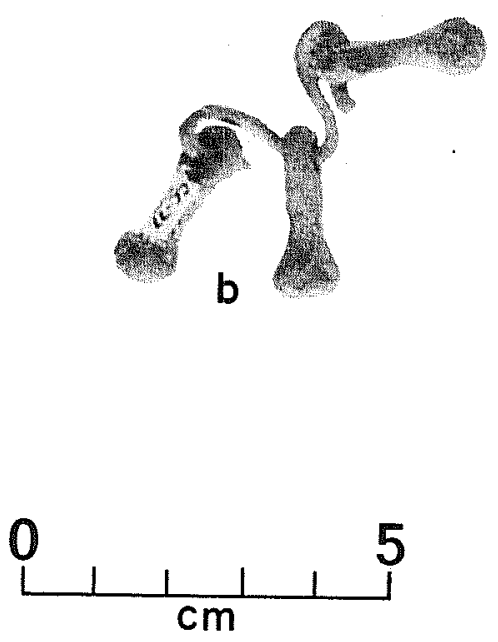

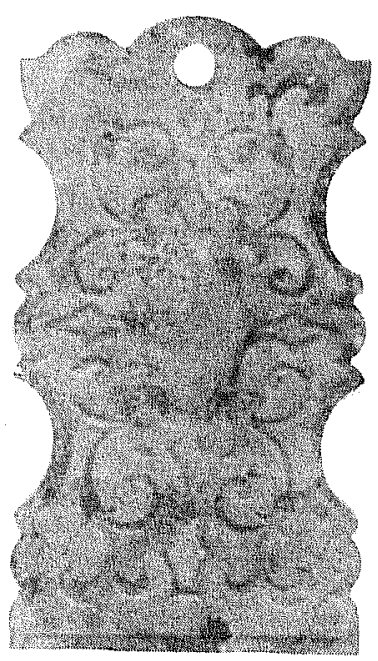

C

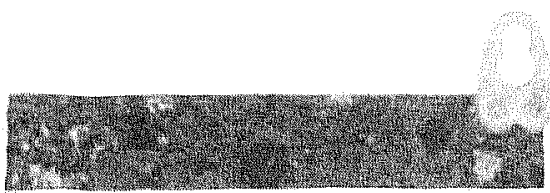

d
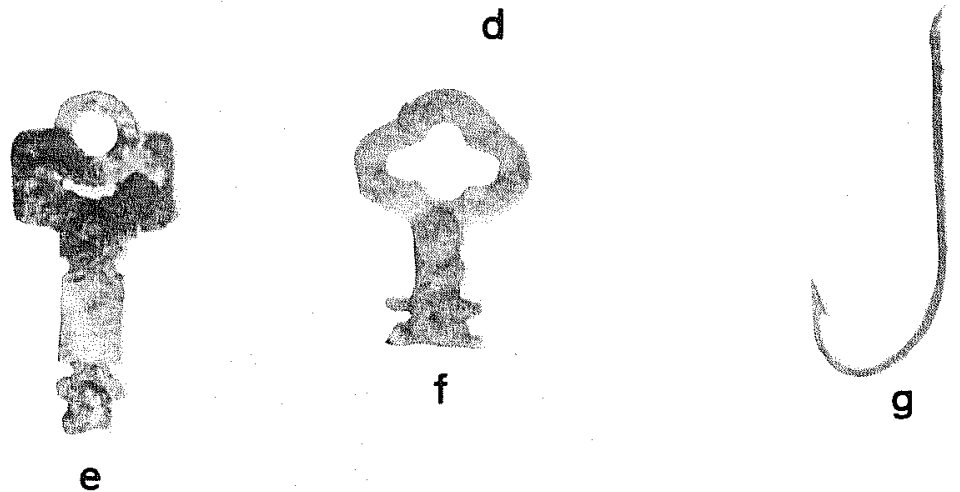

Figure 9. Stoneware and Household Items. a, stoneware, ink bottle rim and sherd; b, metal bell clapper assembly; c, decorative brass plate; d, door plate; e-f, metal keys; g, fish hook. 
White glazed with blue speckles

This ware is of an unknown make and age, consisting of three sherds (same vessel) of a ware with light yellow hard paste, opaque white underglaze, blue speckled or sprayed-on color on one edge, and clear overglaze. There is some faint crazing of the underglaze and the glaze surface is a smooth shiny metallic-like finish. Vessel is a large open bowl with an outward flaring embossed rim.

\section{Porcelain}

Objects of porcelain were various but included vessels, insulators and unidentified pieces (Fig. 6, q-t). Descriptions of individual pieces are included under each site section.

\section{Miscellaneous}

Several unique, nondescript, and unknown wares were recovered and put in a general catchall category, if represented by only one sherd. They will not be further described.

\section{Glass}

Glass material was segregated into four groups based on color: 1) clear, 2) aqua, 3) amber, and 4) green. The overall research design requires information on age and function of objects, neither of which is obtainable from glass color directly. Color was used in order to be consistent with previous analyses and will segregate some functional categories such as snuff bottles or window glass from the general assemblage. The vast majority of the glass sherds are from bottles of various types, some of which bear characteristic manufacturing attributes which are of specific temporal distribution. Some other more complete specimens are identifiable as to function (what they contained or were used for).

Several distinct patterns are of note concerning function vs. glass color. In the clear glass category are the only recognizable glass food preservation or fruit jars. These are of the screw top, external ribbed, and bail latch or lightning closure types. Initiated in 1815, the jar business began to boom with plain cork closures. In 1855 Robert Arthur invented and began manufacture of a tin lid closure. This closure consisted of a saucer-shaped tin lid, the edge of which inserted into a groove in the lip of the jar. It was sealed by pouring melted wax in the groove. Threaded bottles were made as early as the 17 th century in Germany and later in England. The use of threads on wide mouthed jars was adopted in 1858 to accept the famous Mason lids. Mason didn't invent the threaded fruit jar or manufacture jars, only the zinc lids. Glass lids were adopted in the 1870s, and in 1875 the bail latch or lightning stopper was fitted to fruit 
jars. Most early jars were manufactured in light aqua or green colors but other colors were used also (Munsey 1970:146).

Window glass is all aqua colored. Flat glass sherds are, of course, indicative of window panes and reflect the use of windows in buildings. They were expensive and may reflect the affluence of the house owner.

Snuff bottles, being quite distinct in shape, are generally identifiable from any large rim or base sherds.

The categories within the glass material are otherwise self explanatory. The glass items presented in the chronology charts in Table 8 are wares which have restricted temporal distribution and are identifiable from distinct attributes such as manufacturer's mark or method of manufacture.

Metal

Many objects in the frontier home and ranch were made of metal and some, being specialized items, are indicative of some specific use or set of uses. The metal materials were segregated into categories that reflected in part these uses. Agricultural and ranching materials (Fig. 10, d, g-o) are generally recognizable as such and could usually be thought of as being used outside the family living area. Although many frontier families would include the horse and cow as family members and perhaps even keep them in the house, the harnesses and wagon would not be kept with the linen and dishes. Specific items listed in this category were classed into groups of common i.tems.

\section{Construction Materials}

Of all types of hardware, nails are the most diagnostic. Wires, bolts, screws, hinges and wrought pieces (Fig. $8, a-c$ ) were also used in house construction, but their presence is not necessarily indicative of such. Within each site assemblage, the nails (Fig. 11, a) were identified as to type and size (see Table 9 for each site) and frequencies determined. Each of the different sizes and types of nails may be indicative of a general time range or a feature of architecture. The square machine cut nail was not in regular use until 1830, and although it is still made and sold today for special purposes such as roofing and flooring, was not continued in general use much past 1900 . The wire nail was invented in the 1700 s but was not in general use until 1890. Wire nails were used for most purposes after 1900 (Nelson 1968:8-10). 
TABLE 8. SITE CHRONOLOGY CHART.
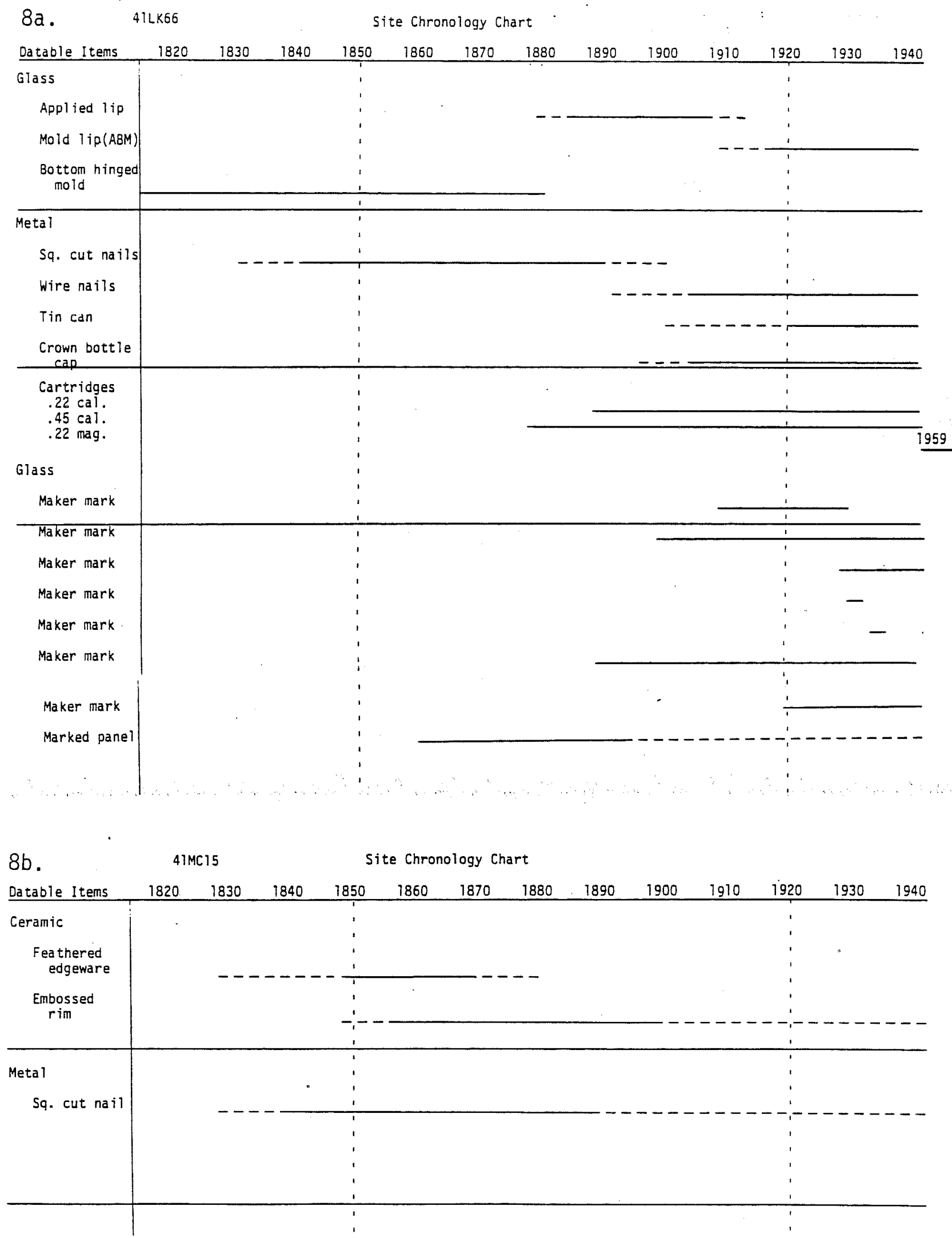
TABLE 8. (continued)
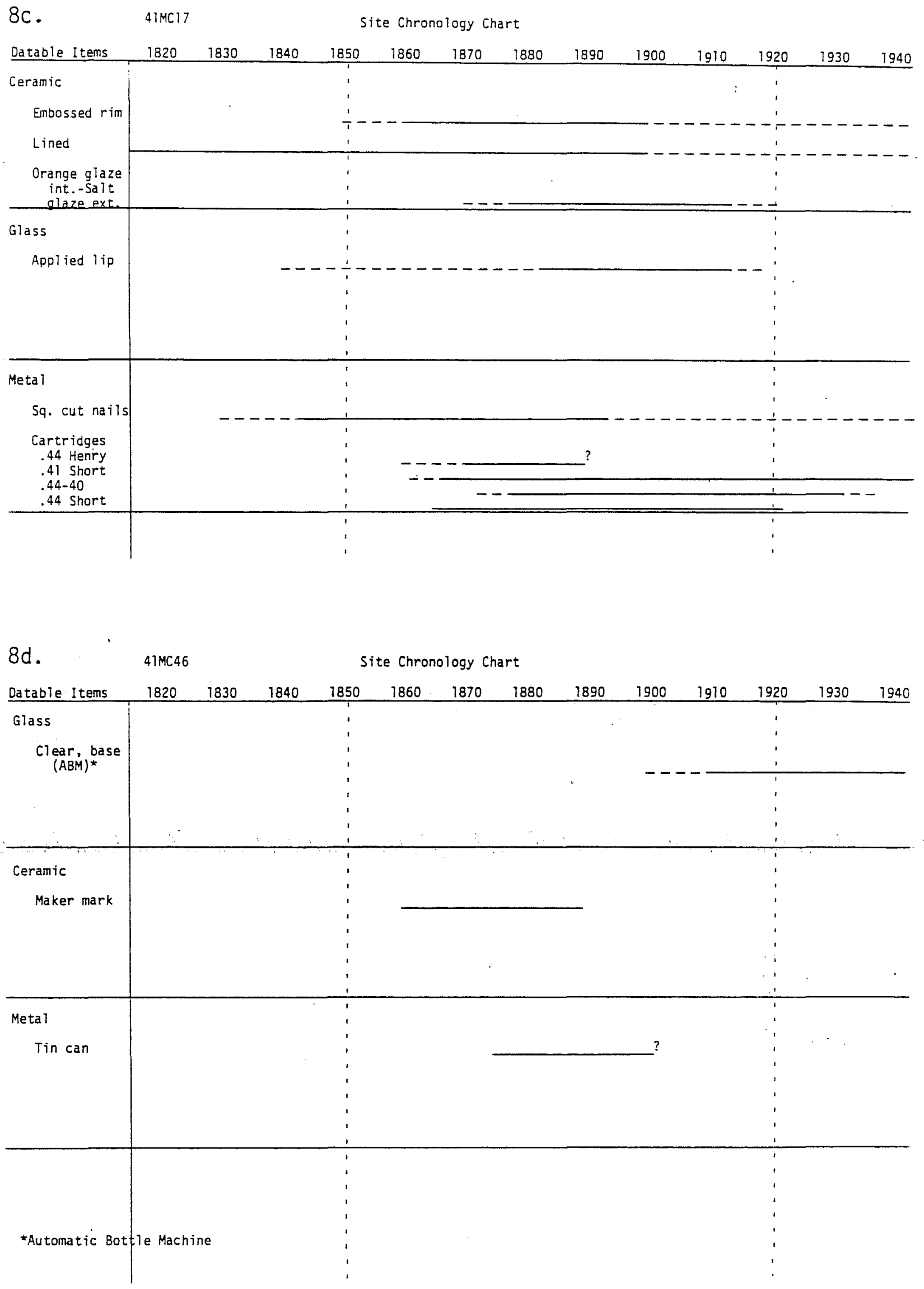
TABLE 8. (continued)
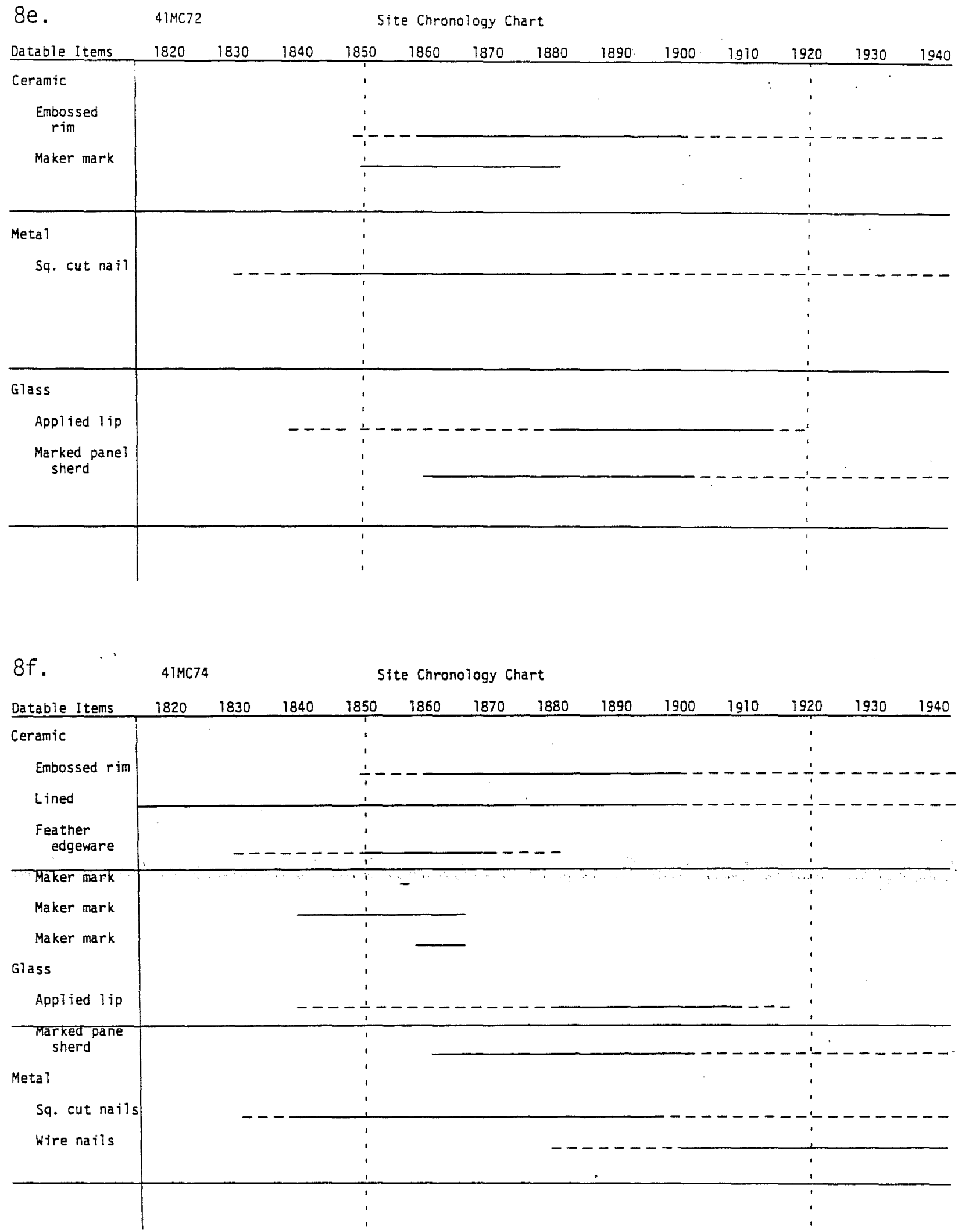
TABLE 8. (continued)
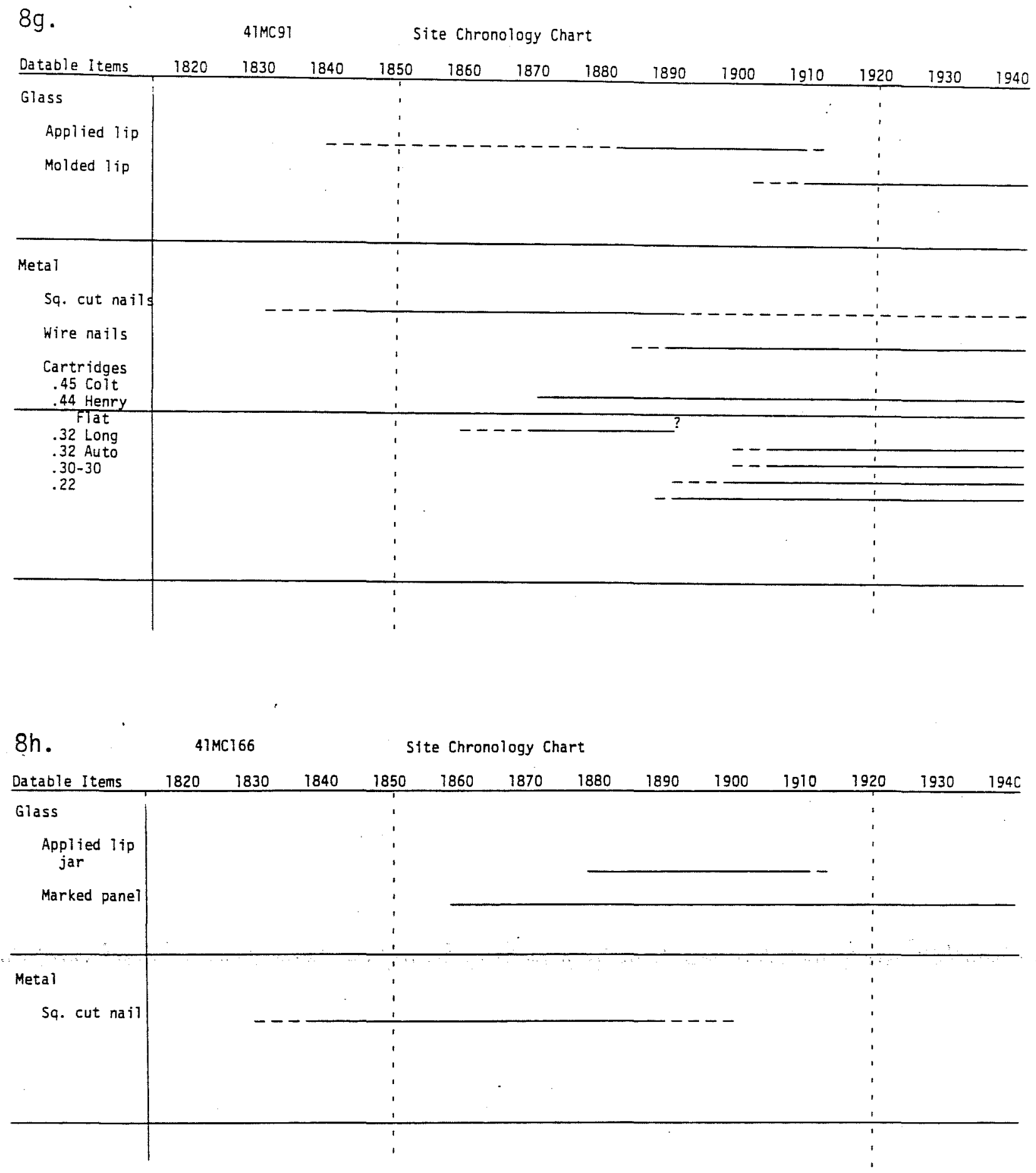
TABLE 8. (continued)

\begin{tabular}{|c|c|c|c|c|c|c|c|c|c|c|c|c|c|}
\hline $8 i$. & & $M C 168$ & & & e Chro & $\log y$ & & & & & & & \\
\hline Datable Items & 1820 & 1830 & 1840 & 1850 & 1860 & 1870 & 1880 & 1890 & 1900 & 1910 & 1920 & 1930 & 1940 \\
\hline Glass & & & & 1 & & & & & & & ' & & \\
\hline Hinged bot- & & & & ' & & & & & & & ' & & \\
\hline tom mold & & & & 1 & & & & & & & ' & & \\
\hline Maker mark & & & & 1 & & & & & & & ' & & \\
\hline & & & & ; & & & & & & & 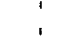 & & \\
\hline Maker mark & & & & . & & & & & & & ; & & \\
\hline & & & & 1 & & & & & & & ' & & \\
\hline Metal & & & & ; & & . & & & & & $\because$ & & \\
\hline $.45 \mathrm{cal}$. & & & & : & & & & & & & 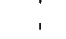 & & \\
\hline colt cart- & & & & ' & & & & & & & - & & \\
\hline ridge & & & & ; & & & & & & & $\div$ & & \\
\hline & & & & , & & & & & & & . & & \\
\hline & & & & ! & & & & & & & ' & & \\
\hline & & & & $\therefore$ & & & & & & & 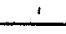 & & \\
\hline & & & & 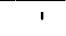 & & & & & & & I & & \\
\hline Ceramic & & & & i & & & & & & & , & & \\
\hline Maker mark & & & & , & & & & & & & ? & & \\
\hline & & & & 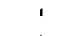 & & & & & & & 1 & & \\
\hline & & & & ; & & & & & & & ; & & \\
\hline & & & & 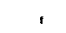 & & & & & & & ' & & \\
\hline . & & & & ; & & & & & & & ; & & \\
\hline & & & & ' & & & & & & & : & & \\
\hline
\end{tabular}

$8 j$.

$41 \mathrm{MC} 775$

Site Chronology Chart

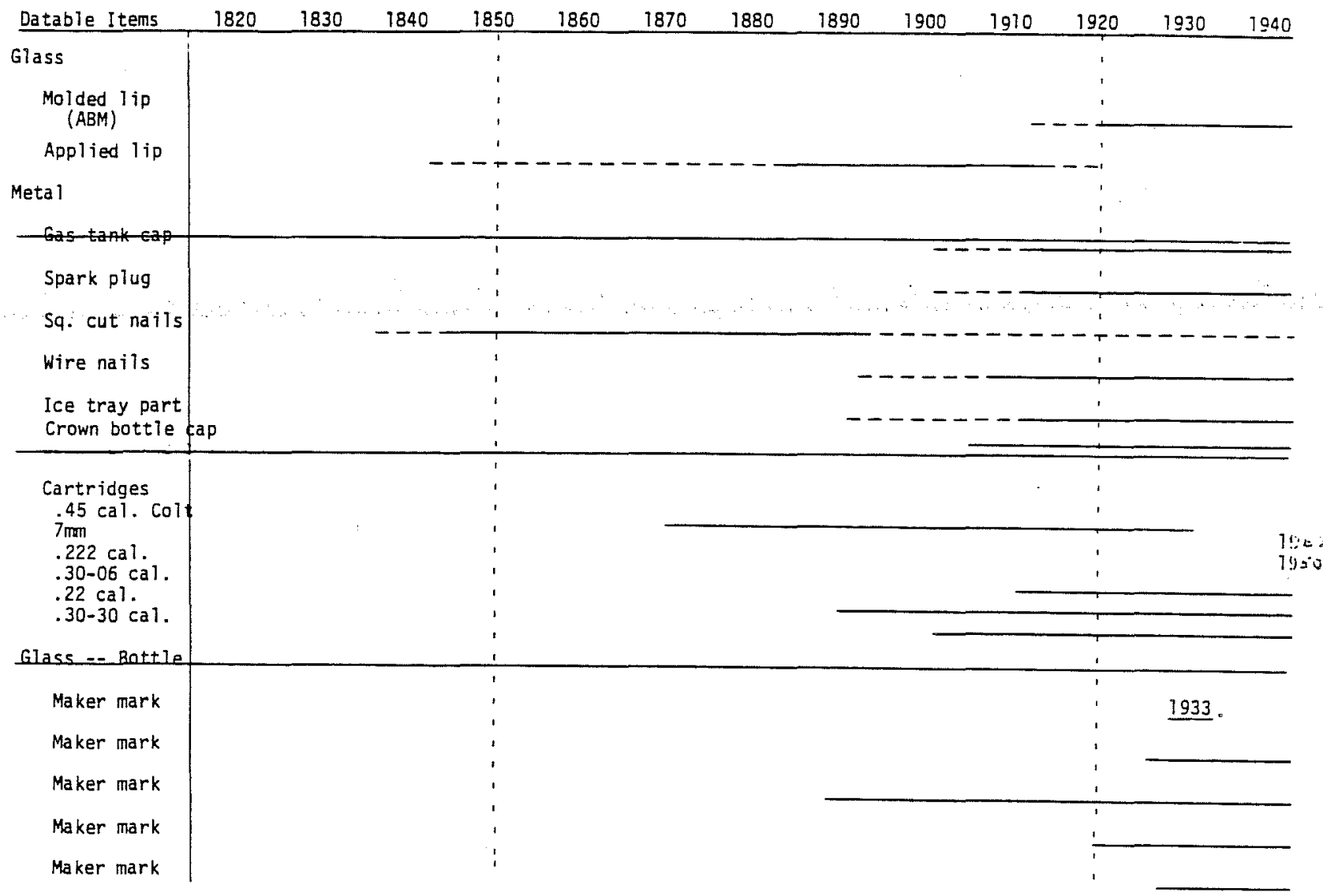


TABLE 8. (continued)
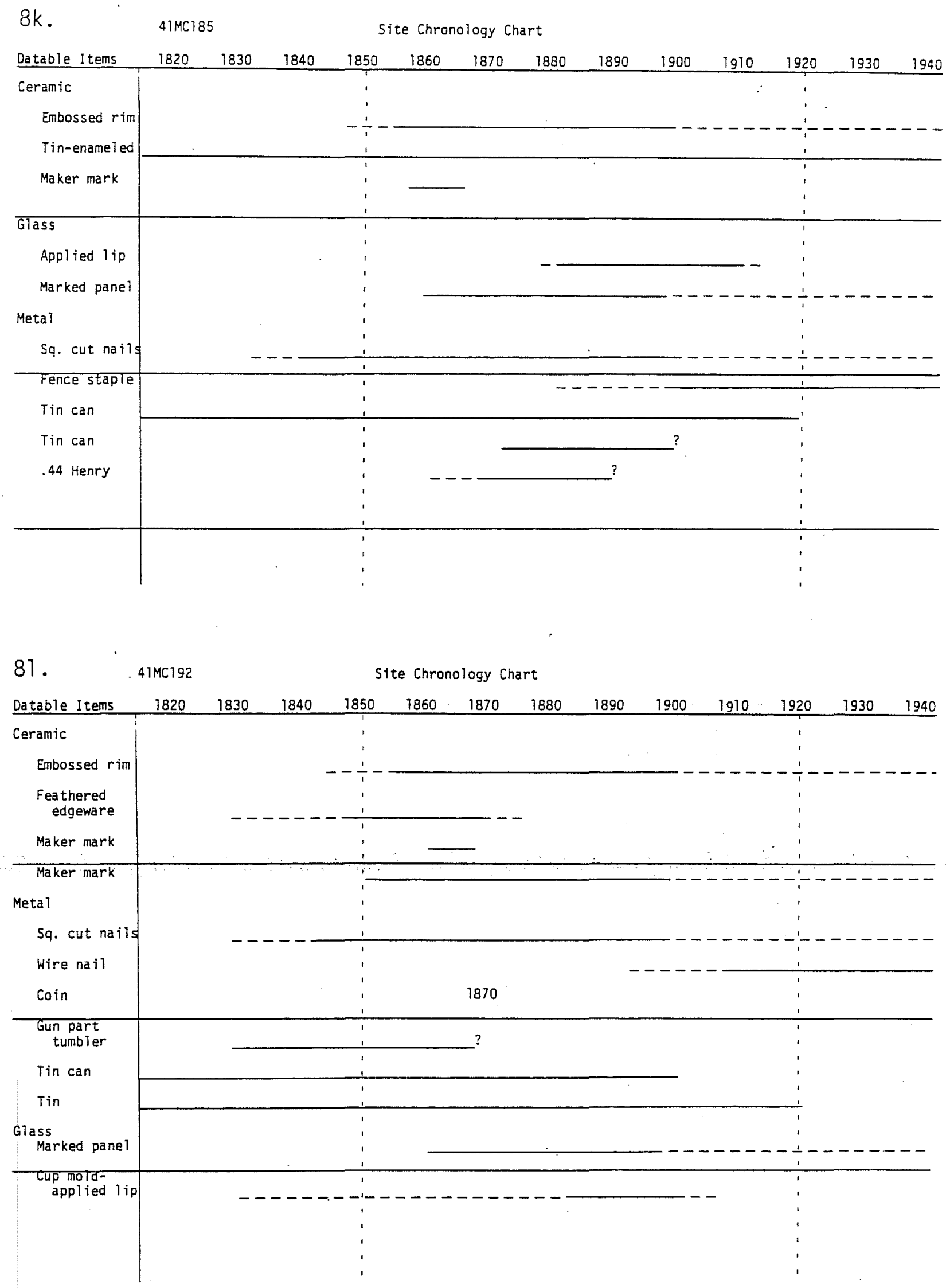
TABLE 8. (continued)
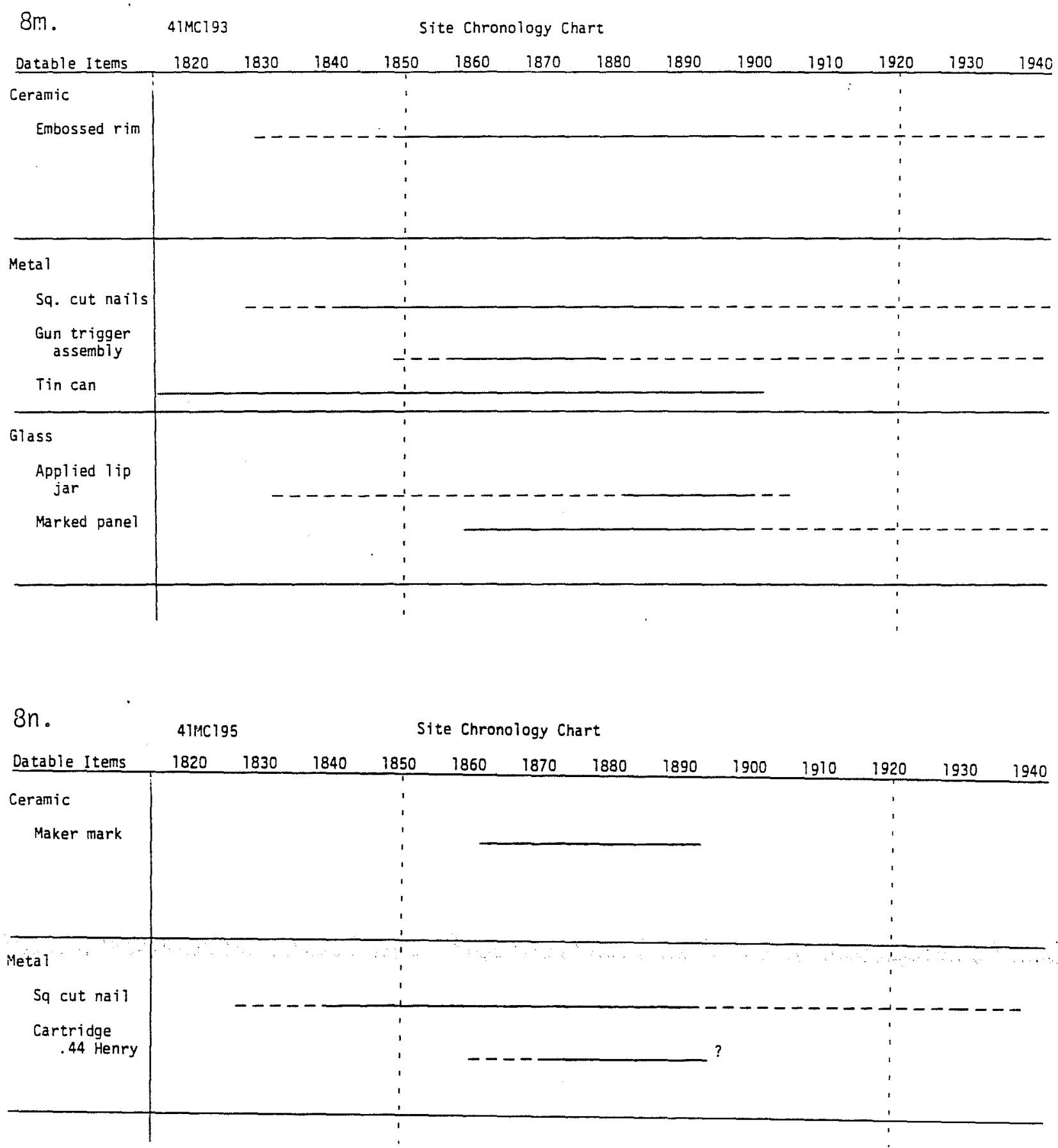


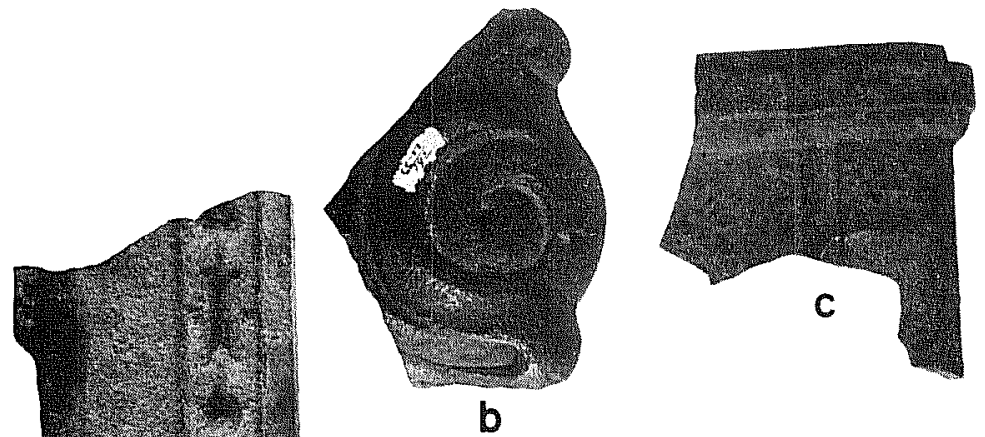

b
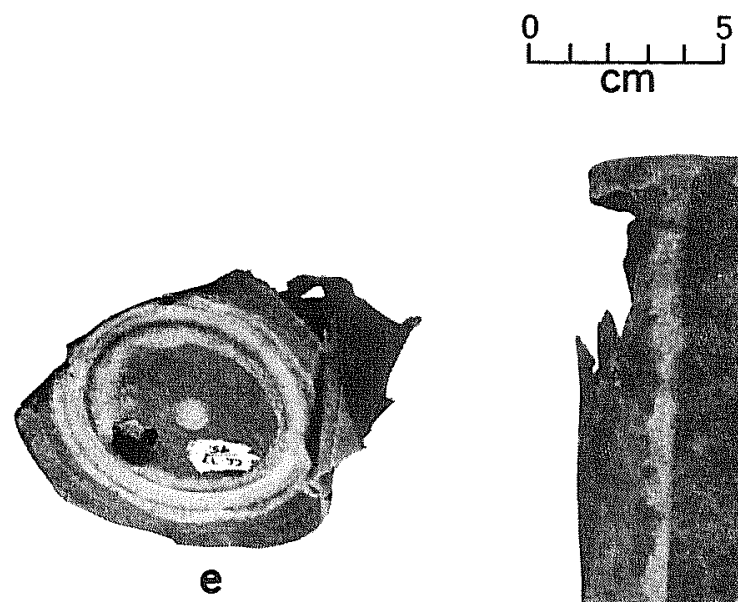

\section{a}
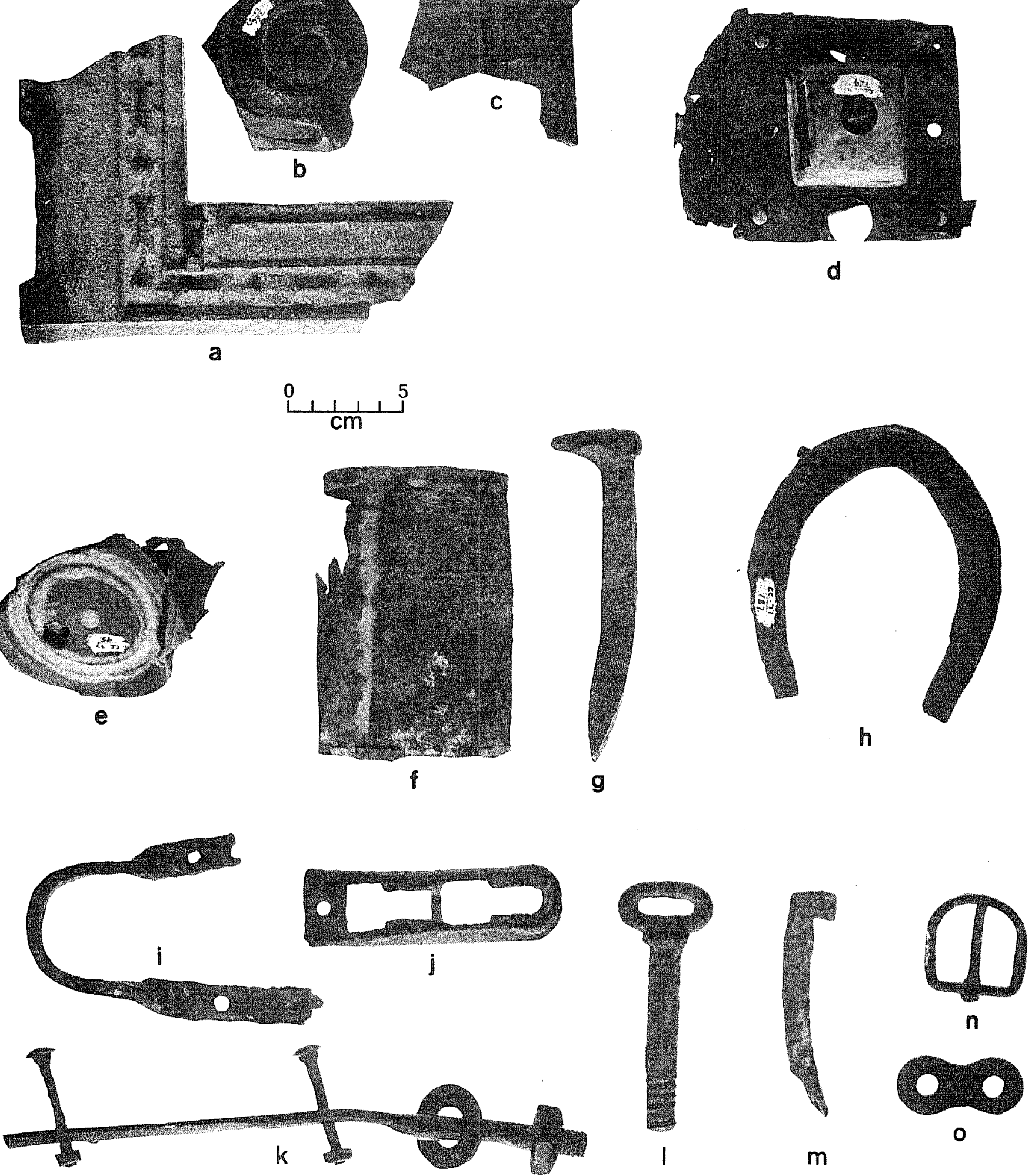

Figure 10. Household and Metal Artifacts. a-c, cast iron stove fragments; d, meta1, probably harness piece; e, tin can top showing the soldered "hole in the top" and a center vent hole also soldered; $f$, soldered side seams and lap seam ends; $g$, metal railroad spike; $h$, metal horse shoe; $i-k$, metal wagon parts; 1 , thread slotted bolt; $\mathrm{m}$, unidentified cast iron object; $\mathrm{n}$, harness buckle; $\mathrm{o}$, chain link piece. 
FIGURE 11. Metal Items, Gun Parts and Ammunition.
a. square cut nails
b. guntrigger assembly from 41MC193
c. molded bottle lip, made in automatic bottle machine, 41MC46
d. coin, silver 5 centavos piece, Mexican dated 1870
e. chamber pot cover (?), $41 \mathrm{MC17}$

f-k. ammunition cartridges

f. percussion cap

g. .41 caliber short

h. .44 caliber Henry short

i. .44 caliber Henry (medium length)

j-k. .44 caliber Henry long made by Union Metallic Cartridge Company, (41MC17)

1-p. ammunition cartridges head stamps

1. .41 caliber short fired in a pistol

m. .44 caliber short fired in a pistol

n. .44 caliber fired in Henry rifle. Paired firing pin indentations, indicative of the Henry rifle, show this cartridge to have been misfired twice before finally firing

o-p. .44 caliber Henry made by Union Metallic Cartridge Company 

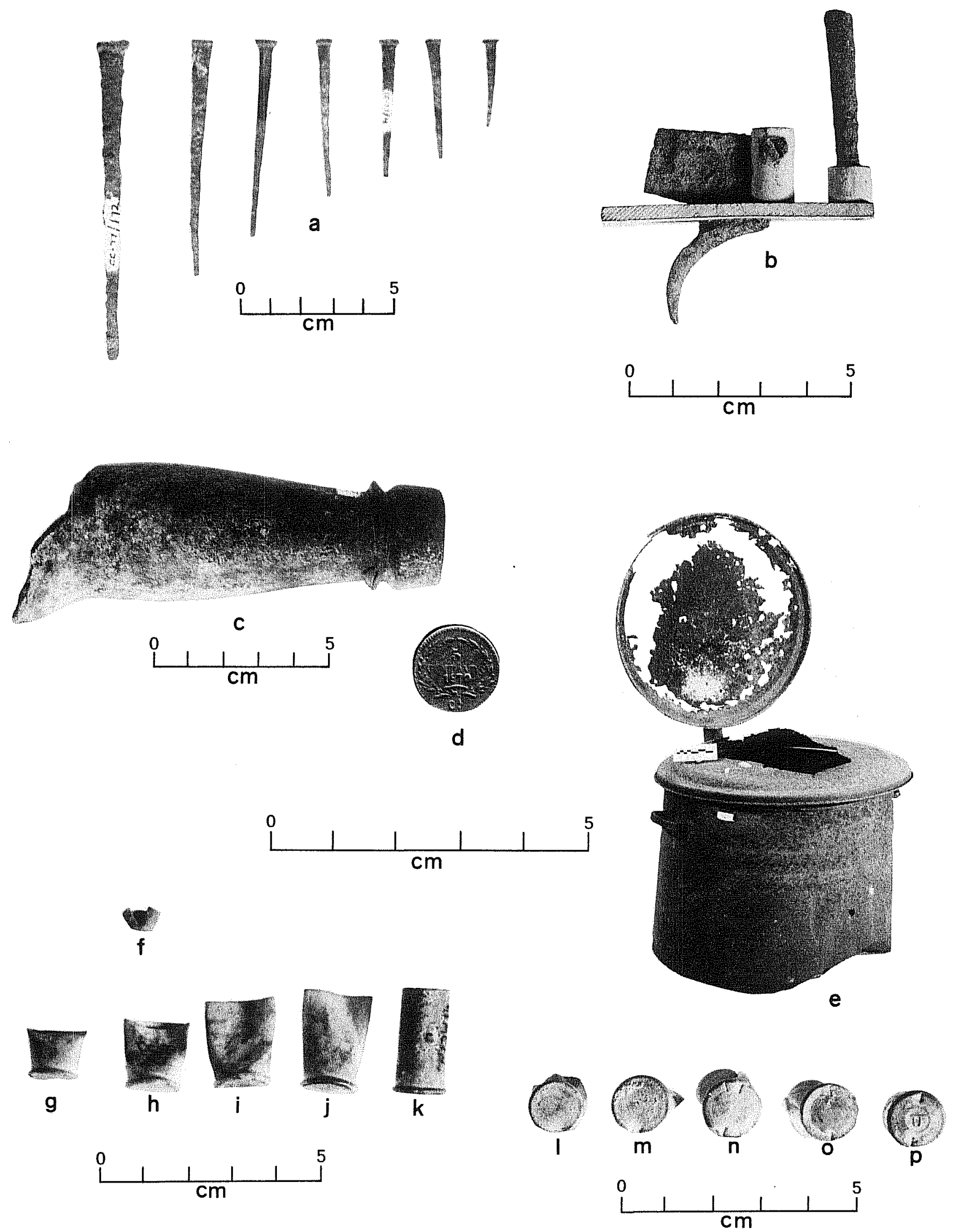
5 
TABLE 9. NAIL TOTALS FROM EACH SITE.

Square Cut

ID $\quad F R$

Common

Wire

\begin{tabular}{|c|c|c|c|c|c|c|c|}
\hline \multirow{2}{*}{\multicolumn{8}{|c|}{ Site Number }} \\
\hline & & & & & & & \\
\hline 41LK66 & 93 & 33 & 93 & 6 & 18 & 1 & 46 \\
\hline $41 \mathrm{MC} 15$ & 51 & 24 & 1 & & & & \\
\hline $41 \mathrm{MC} 17$ & 97 & 62 & 1 & & & & \\
\hline $41 M C 72$ & 15 & 9 & & & 1 & & \\
\hline $41 M C 74$ & 33 & 3 & 1 & 1 & & & \\
\hline 41MC91 & 18 & 2 & 8 & & 3 & & \\
\hline $41 M C 166$ & 1 & 1 & & & & & \\
\hline $41 M C 168$ & 3 & & & & & & \\
\hline $41 M C 175$ & 5 & 3 & 16 & & 4 & 3 & 1 \\
\hline 41MC185 & 31 & 7 & & & 2 & & \\
\hline 41MC192 & 29 & 10 & 2 & & & & \\
\hline 41MC193 & 7 & 2 & & & & & \\
\hline 41MC194 & 3 & & & & & & \\
\hline 41MC195 & 1 & & & & & & \\
\hline
\end{tabular}


Household Items

The items generally associated with homemaking and housekeeping are of three general groups: 1) general house and garden, 2) kitchen implements, and 3) miscellaneous household. General house and garden items found include a garden hoe head, mop head (Fig. 7, d, e), oil lamp and items of general furniture or housekeeping nature. Kitchen implements (Fig. 8, d-f, i) include such items. Miscellaneous household items (Fig. 8, h; 9, b-g) are on the same list. The use of metal food storage canisters (tin cans) is a relatively recent phenomenon, being invented by Heine and Durand in 1810. The general use of cans did not occur until later in the 1800 s (Fontana and Greenleaf 1962:67). Numerous innovations occurred in the canning industry, and in general they are summarized as follows:

$$
\begin{aligned}
\text { hole in the top (Fig. 10, e) } & 1815-1900 \\
\text { tapered meat can } & 1875-\text { ? } \\
\text { fold locked seam - } & \begin{array}{l}
1900-\text { present, not } \\
\text { popular until } 1920 \mathrm{~s}
\end{array} \\
\text { soldered seam (Fig. 10, f) - } & \begin{array}{l}
1815-1920, \text { fading } \\
\text { after } 1900, \text { continued } \\
\text { to present in milk cans }
\end{array}
\end{aligned}
$$

Crown bottle caps, which were crimped onto the bottle top, came into use in 1907 (Fontana and Greenleaf 1962:73). Not only is this cap readily identifiable, but the bottles were designed specifically to accept such a cap.

\section{Personal Items}

Personal items are those articles associated, at least temporarily, with a specific individual. Clothing parts, jewelry, toys, and other metal items are simply listed under the outline heading. The purpose of listing a series of functionally dissimilar items under a common heading is to compile in one specific area (of the table) items which might be indicative of a specific individual by sex or age. Any particularly diagnostic items in this category are discussed in specific site sections. The first criterion of division in the assemblage is by material; such items as buttons appear in numerous places in the inventory, depending upon what material they are made of, i.e., glass, plastic, or metal.

\section{Cast Iron}

The cast iron material is a break in the function categorization and was used mainly because of the difficulty in identifying specific items. Most recovered cast iron items were fragments of flat objects, 
probably stove parts (Fig. 10, a-c) or cookware. The stove could also fit in to the general household or kitchen category.

Gun Parts and Ammunition

Various ammunition cartridges and a few gun parts which are easily dated were recovered. Guns and ammunition probably have better documentation available than that of any other class of artifacts, due mainly to their extreme popularity with collectors and the voluminous manufacturers' records associated with military work and patents. Specific items are discussed in the particular site descriptions.

Other Objects

The last category is an accumulation of various materials that are either rare, very late, or perhaps of natural origin (ecofacts). objects of plastic date to the recent 20 th century as do most objects of readily perishable material. The exposed nature of most of the sites does not facilitate good material preservation. (except in association with extant structures). Rubber objects are not common (probably due to poor preservation), although objects were commonly made of hard rubber during the late 19th century. Numbers of shells and presence of bone were recorded in the materials inventory.

\section{Prehistoric Artifacts}

Most historic habitation sites in the project area are situated on terraces or other localities previously inhabited by prehistoric people. These prehistoric materials most probably have no temporal association at all with the historic Anglo or Mexican inhabitants and are included here as a matter of record. Several sites such as $41 \mathrm{MC} 15$ and $41 \mathrm{MC} 17$ have extensive prehistoric components which have been tested and evaluated by the UTSA field crews and will be fully reported and analyzed in their work. Lithic artifacts and chipping debris were recorded and, where possible, identified in the materials inventory. 
SITE DESCRIPTIONS

41LK66 Nichols House (Surface Collection and Intensive Testing)

Description

Consisting primarily of an extant structure ("Nichols House") and some associated features, the site was investigated and documented with a plane table map (Fig. 12), three test pits, plan maps of architectural details, and controlled surface collections. The specific remains associated with the structure include scattered historic occupational debris, a water cistern and several outbuilding structural remains. One outbuilding (Fig. 13) is located $25.9 \mathrm{~m}$ north of the house. At a point midway between the two structures a demarcation line was established separating the two and designating area $\mathrm{A}$ associated with the extant house, and area $\mathrm{B}$ associated with the northern outbuilding. Surface collections were then carried out separately.

The front of the house apparently once had a porch (see side elevation, Fig. 14, a). Test pit 非 (see floor plan, Fig. 15) was situated outside the front door extending $2.5 \mathrm{~m}$ to slightly past the outer foundation wall of the front porch. This test pit was 1m wide and subdivided into two parts, the western, inside the porch foundation and the eastern, outside the foundation. The interior portion of the pit was excavated to a depth of $65 \mathrm{~cm}$. Most of the artifacts recovered here were from the surface and included some very recently introduced materfals, such as modern bottle caps. However, some items were found at deeper levels. The matrix within the foundations is fill dirt in the upper $30-35 \mathrm{~cm}$, with a thin $(2 \mathrm{~cm})$ layer of light gray sandy loam soil on top, possibly representing dirt which had settled through the porch floor while the house was occupied. The fill is a light to dark (mottled and mixed) sandy clay loam with gravels, rootlets, and rodent burrows. This fill grades into a zone with yellow-tan sandy clay soil and mixed chert gravels which is probably the original ground surface at the time of the house construction. Below this is a basal soil zone of mottled yellow-tan calcareous clay with a few white calcareous (?) nodules and chert gravels. The eastern part (about one-fourth) of the pit, outside the porch wall, was excavated to a depth of $35 \mathrm{~cm}$ and contained the largest number and types of artifacts (see artifact inventory, Table 7). Artifacts were restricted to the upper $15 \mathrm{~cm}$ outside the foundation. The porch wall construction used rather small rounded cobbles, with generous amounts of mortar in lumps, to build a foundation about $30-40 \mathrm{~cm}$ wide, set in a narrow trench no more than $20-25 \mathrm{~cm}$ deep. No evidence of the extent of the footing trench was found, so it is assumed to have been nearly filled with 
占

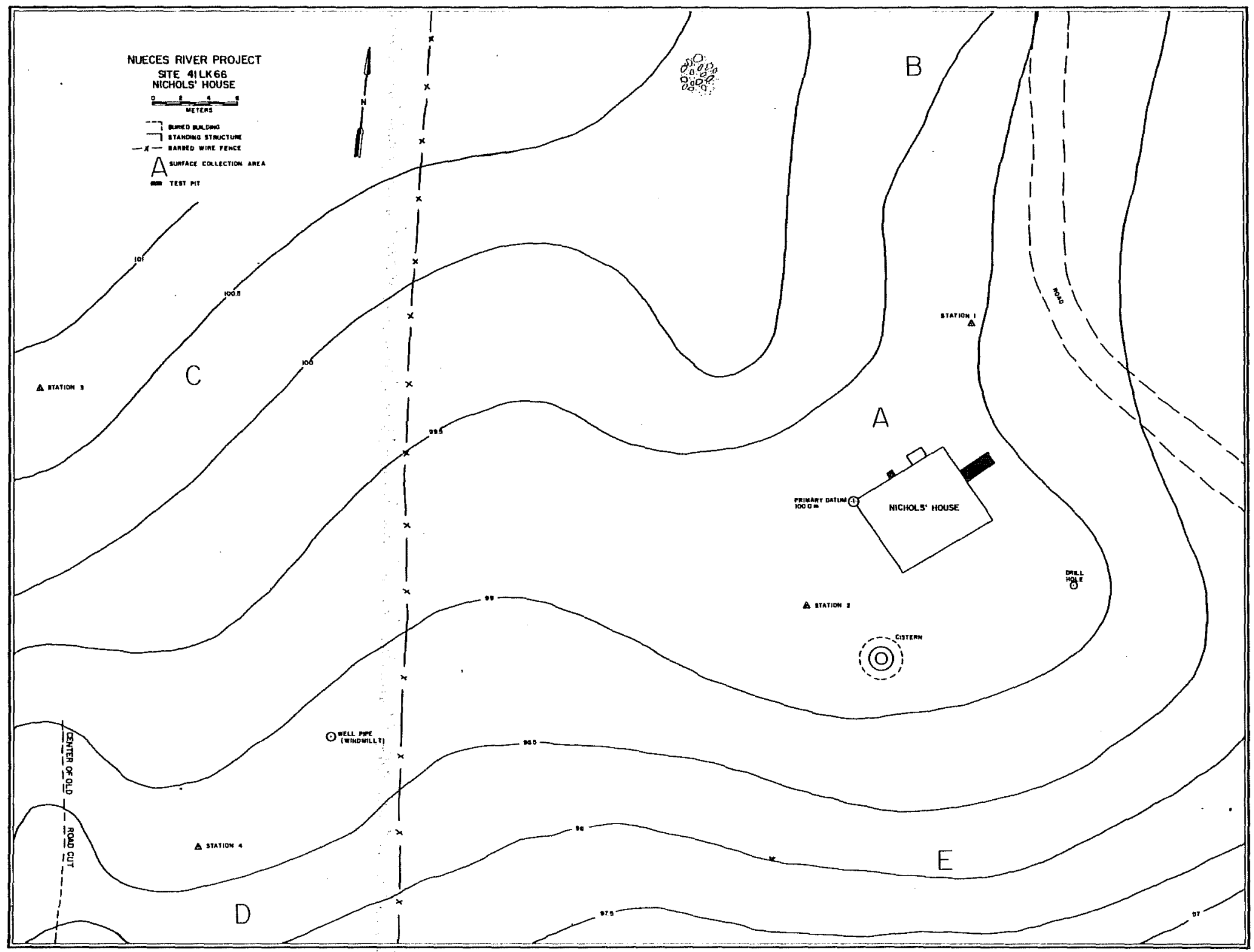

Figure 12. Map of Site 47LK66-Nichols House. 


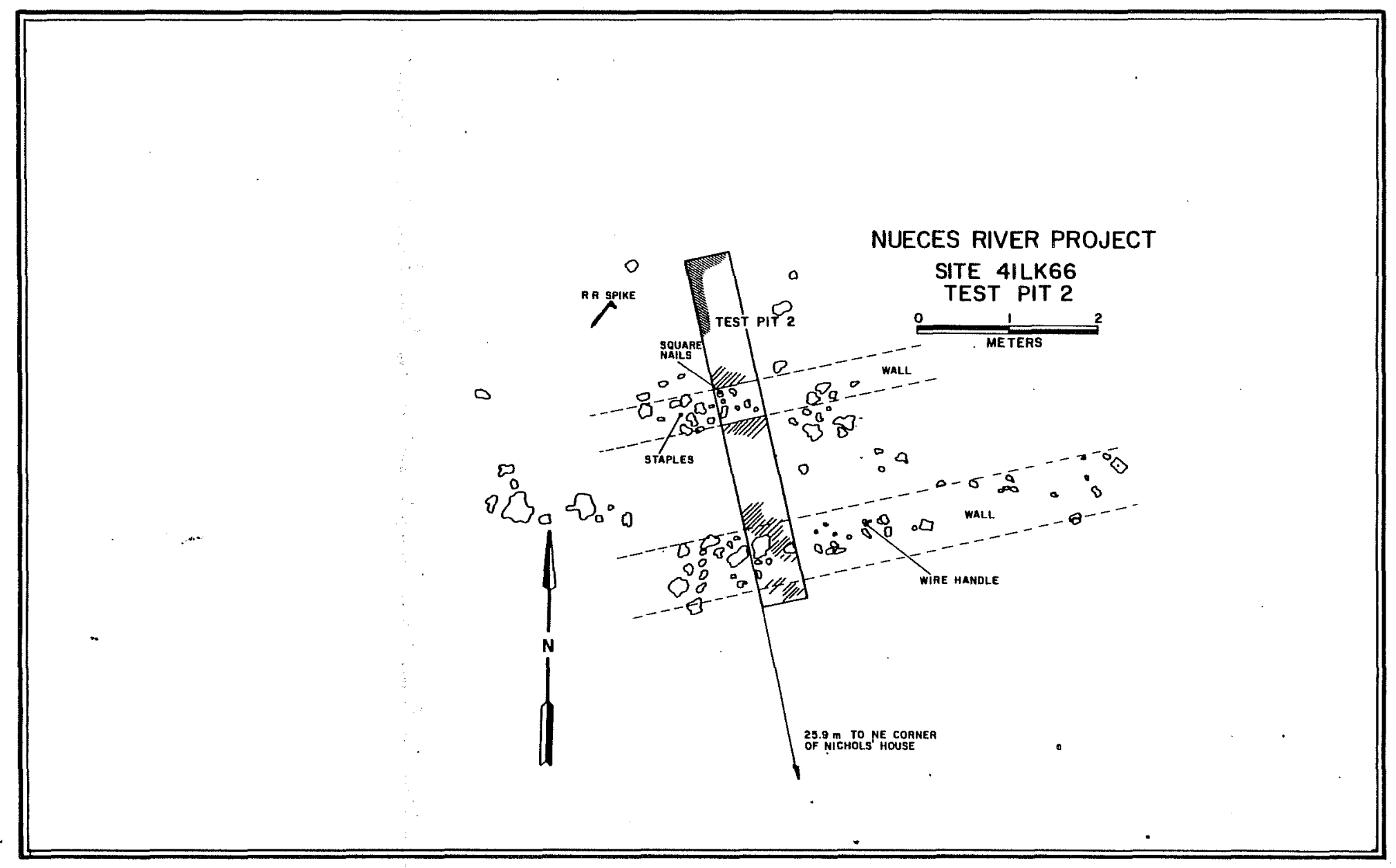

Figure 13. Test Pit 2 and North Outbuilding, 41LK66. 


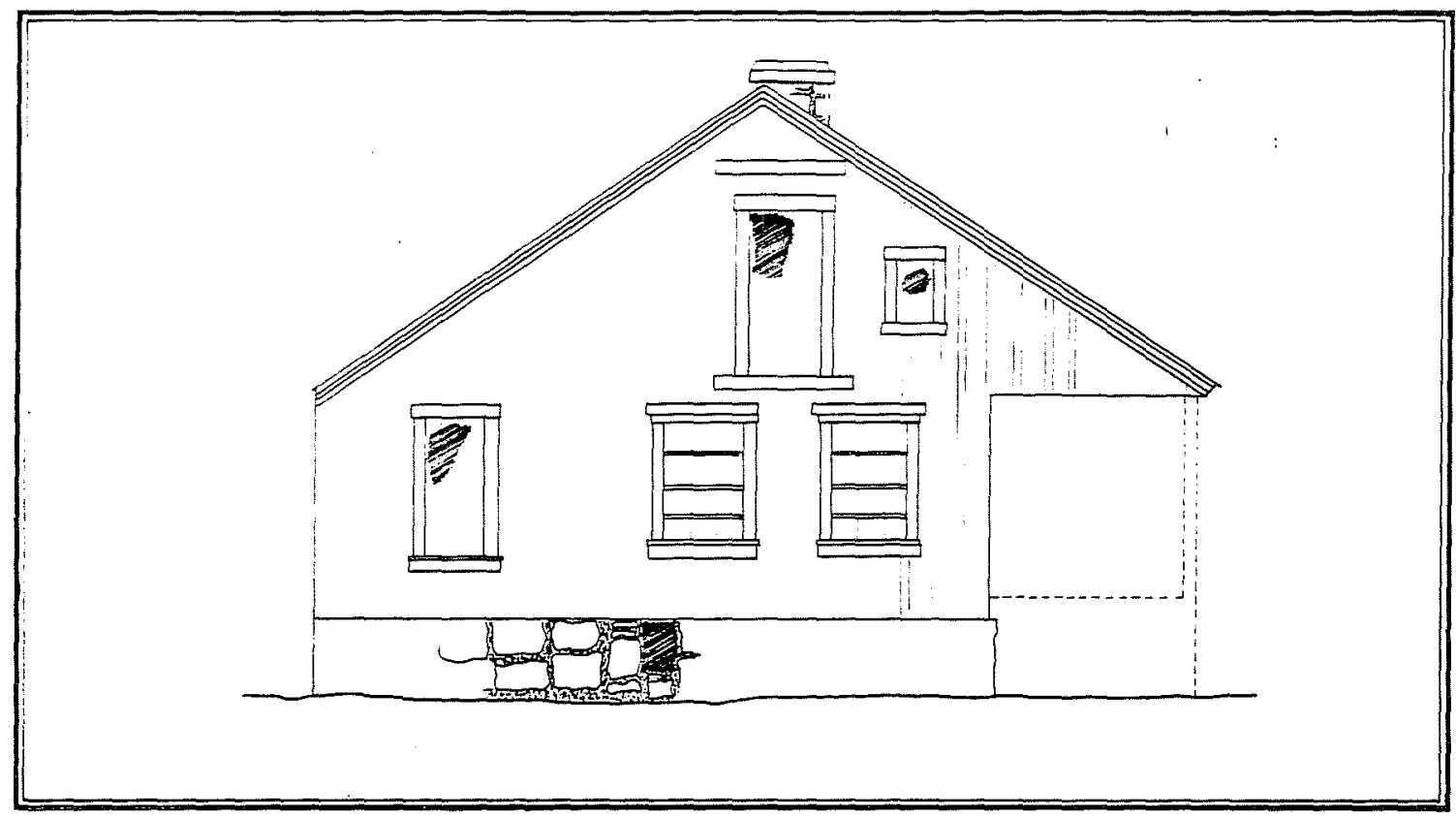

a

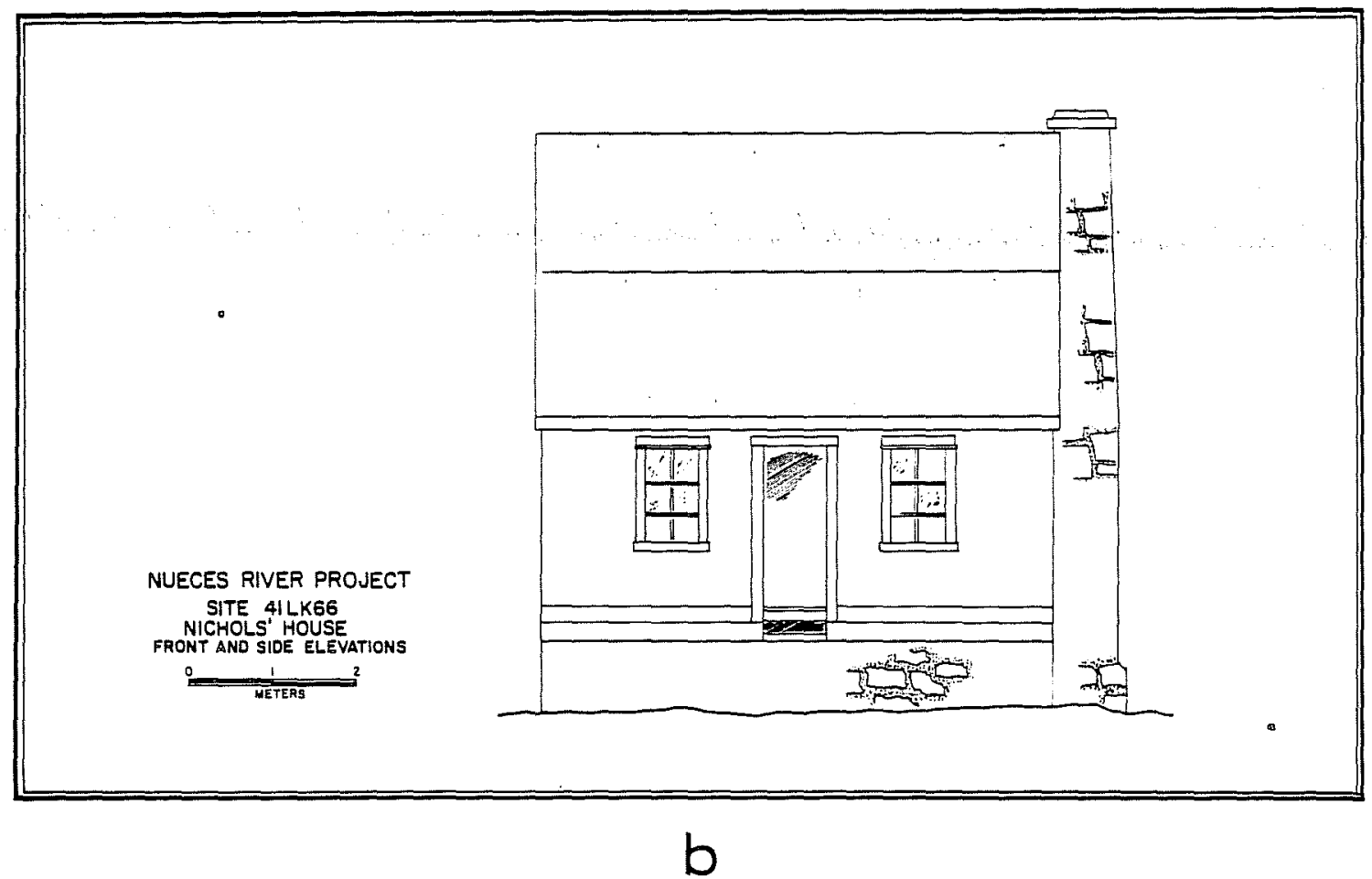

Figure 14. Elevations of Extant House 41LK66. a, side; b, front. 


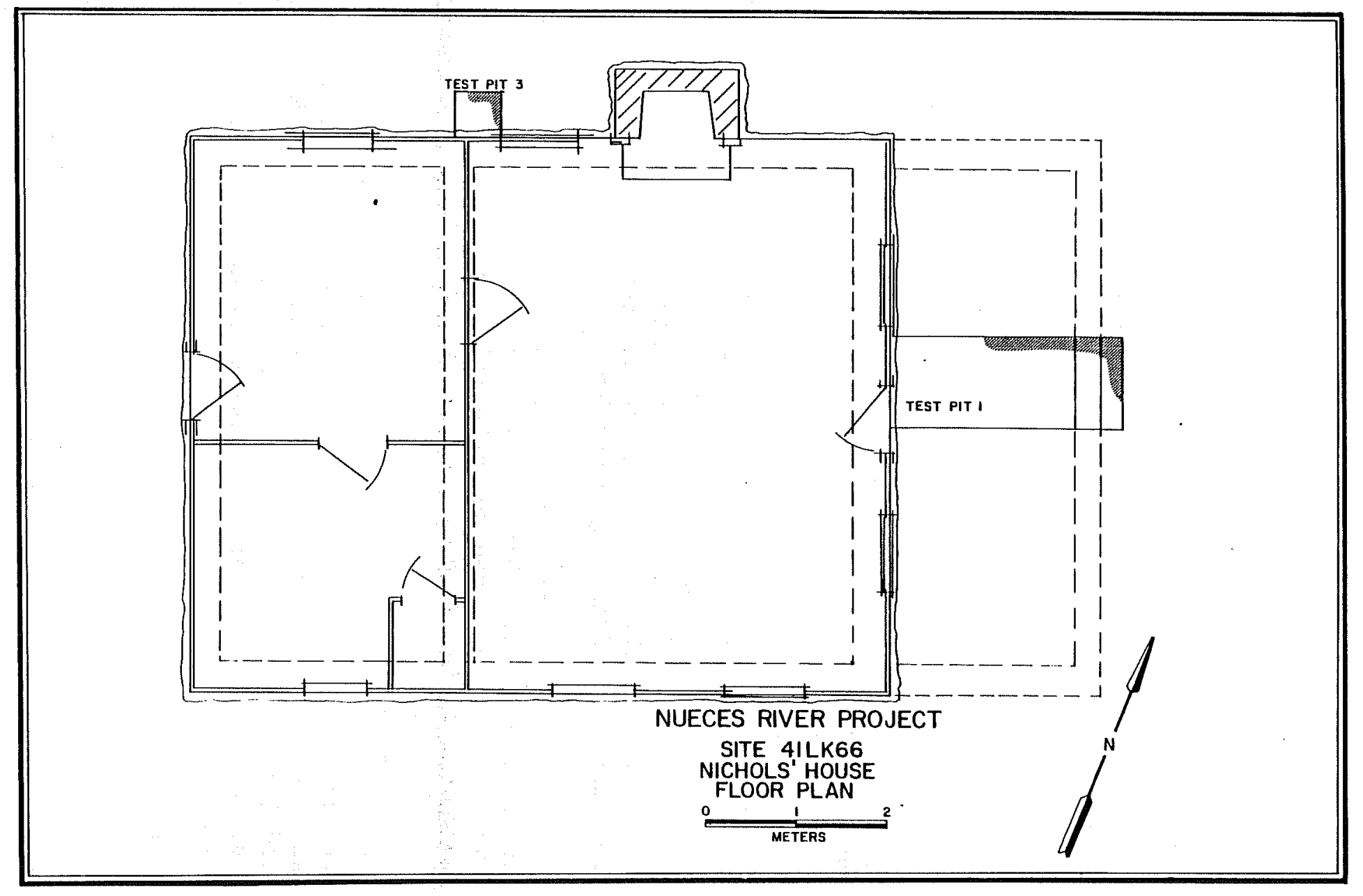

Figure 15. Floor Plan of Nichols House, $41 \mathrm{LK} 66$. 
the foundation materials. The western $50 \mathrm{~cm}$ of the pit (against the house foundation) revealed this foundation to be very similar to that made for the porch. There is a distinctly different selection of materials used in the upper as opposed to the lower parts of the house foundation. As described above, small rounded cobbles with generous amounts of mortar were used to cap the lower parts of the foundation. On top of this is a layer of mortar with a series of semi-shaped blocky sandstone rocks set in mortar for the balance of the foundation wall (see elevations, Fig. 14). There has been a noticeable amount of deterioration of the lower part of the foundation, due mainly to the heavy usage of mortar, which is becoming crumbly.

Test pit 33 was excavated against the north wall of the house (see floor plan, Fig. 15). This pit is $50 \mathrm{~cm}^{2}$, excavated as one level to a depth of $35 \mathrm{~cm}$ below the ground surface, with the same results as test pit $\#_{1}$ except no occupational debris was recovered.

Test pit 非 2 was a $0.5 \times 4 m$ trench $10 \mathrm{~cm}$ deep which transected the foundation of the northern outbuilding (Fig. 13). This structure was originally located by a concentration of small rocks scattered on the ground surface. As brush, grass and humus were removed by shovel scraping and a broom, historic cultural materials were encountered (square cut nails, bottle glass, wire, etc.). An area of about $4 \mathrm{mx} 7 \mathrm{~m}$ was cleared with some items mapped in, and pit 非 was put in to transect the apparent concentration. The full dimensions of the structure could not be obtained, but the two exposed foundations are about $2.25 \mathrm{~m}$ from outside edge to outside edge. The northern wall, much more well defined and preserved than the southern wall, is about $40 \mathrm{~cm}$ wide. The wall footing is constructed mainly of rocks and gravels with no mortar, and is only about $5 \mathrm{~cm}$ thick.

Additional associated features include the fully collapsed and scattered remains of a barn and set of stock pens in an area about $65 \mathrm{~m}$ west of the house and an outbuilding locality at mapping station 非 3 . South of these buildings is an erosion gully that is situated and shaped such that it may be an old road. Recent disturbance and damage have been inflicted in this area by brush clearing and road building activities. The cistern is located 6m south from the southwest corner of the house. It is constructed of mortared rocks with about $5 \mathrm{~cm}$ thick concrete plaster interior and exterior. The cistern is $3.21 \mathrm{~m}$ deep with a bell shaped interior, and the mouth extends $0.71 \mathrm{~m}$ above the ground surface. The slope to the south of the house is strewn with occupational debris and trash.

The extant house is $10 \mathrm{~m} \times 6.2 \mathrm{~m}$ with three rooms measuring $4.5 \mathrm{~m} \times 6.2 \mathrm{~m}$, $3 \mathrm{~m} \times 2.6 \mathrm{~m}$, and $3 \mathrm{~m} \times 3.4 \mathrm{~m}$. One room, the smallest, has a $1 \mathrm{~m}^{2}$ closet. A front porch, 2.3m deep, went across the entire front of the house. The exterior and interior walls of the house are set on a masonry foundation. The construction shows both wire and square cut nails with many of the wire nails from relatively recent repairs. The house interior walls are finished with a pressed fiber wallboard under which is a wall covered with at least three and perhaps more layers of wallpaper 
under which is newspaper against the lumber planks. One piece of recovered newspaper bears the date 1908. This particular piece of newspaper was found on the east wall of the northwest room, between the door and the north wall. This room had been covered with wallboard. The association of this newspaper to that on the walls in the rest of the house is not known. As far as is known, only the largest room had printed wallpaper over the newspaper.

\section{Artifacts}

The artifacts (Table 7) are of the types common at other project historic sites and indicate habitation at the site from the late 19 th century until perhaps as late as the 1960s. Some artifact classes have differential distributions which may be a function of activity areas or behavior patterns. The most common occurrences of plain undecorated earthenware sherds are in areas $A$ and the downhill dump. The decorated earthenware sherds are found only in the hillside dump, and no earthenware at all is found associated with the northern structure (test pit 非).

\section{Chronology}

Datable artifacts (Table $8 \mathrm{a}$ ) indicate occupation at the site since the late 19 th century. The proportion of wire to square cut nails is relatively high (Table 9).

Of the identifiable tin cans at LK66, one is of open top, locked seam manufacture of the "tobacco can" type, with a wire hinge around the top for opening and closing. The development of the open top, locked seam can depended upon the development of suitable machinery for forming and rolling a hermetic double seam. The diagnostic feature of this type of can is the locked and lapped seam on the side and the absence of solder for the sealer (Fontana and Greenleaf 1962: 72-73). The locked seam can came into use about 1900 with general acceptance about 1922 (Fontana and Greenleaf 1962:72-73). Another locked seam can could be described as a "baking powder" can. A third variety of locked seam manufacture present at this site is something like a "boot polish" can. Two marked panel glass sherds are present and indicate production after 1860. Of the bottle maker marks identified, two were made by the Owens Bottle Co. of Toledo, Ohio. The use of the "O in a square" trademark was used from 1911 until 1929 when the Owens Bottle Co. with its subsidiary, the American Bottle Co., merged with the Illinois Glass Co. to form the Owens-IIlinois Glass Co. (Toulouse 1971:397).

Three bottle sherds indicate they were produced by the OwensIllinois Glass Co. The particular symbol shown by all three examples was used from 1929 through 1954 (Toulouse 1971:403). Two of these sherds have numbers to the side of the maker mark which indicate plant 
number and year of production. A chart on page 395 of Toulouse's Bottle Makers and their Marks refers to the plant number, where it was located, and when it was operated. The plant number is to the left of the mark and the year of production after the beginning of the plant is to the right of the mark. On one specimen the plant number is not identifiable, but the year of production shows a number one. Assuming the plant began production in 1929, the date for this piece would be 1930. The second specimen from the Owens-IIlinois Glass Co. shows a seven for the plant number and a four for the year of production. The number seven refers to the plant at Alton, Illinois which started in 1929. The fourth year of production would date this piece at 1933. One bottle sherd exhibits the mark used by the Hazel-Atlas Glass Co. of Wheeling, W. Virginia, which operated from 1920 through 1964 using this particular symbol (Toulouse 1971:239-242). One sherd shows the Ball Bros. maker mark which has been used in several variations of design of the lettering of the word "Ball" from 1888 until the present (Toulouse 1971:66-68). Another glass sherd has the Heinz Co. trademark with the "57". This piece probably dates after 1896 since the "57" was not adopted until that time (Toulouse 1971:236-238).

Several ammunition cartridges were identified and dated. A .45 Colt, introduced in 1873, is present. Three .22 long or long rifles which were introduced in 1887 are among the collection for this site. A .22 magnum Winchester Super $X$ which was not produced until 1959 is also in the collection.

\section{$41 \mathrm{MC} 15$ (Surface Collection and Intensive Testing)}

\section{Description}

The remains evident at this site are scattered sandstone and historic occupational debris and at least one architectural feature. The site, much larger at one time, presently covers an area about $15 \mathrm{~m} \times 30 \mathrm{~m}$. The site is situated on the western margin of a fossil flood plain overlooking the Frio River 10m to the west. Erosion from the Frio River has removed parts of the site on the western edge, the lower slopes below the site being strewn with sandstone blocks and historic occupational debris. A gully to the south of the site (Fig. 16) has removed a segment of that end of the site. A distribution map of the scattered sandstone (Fig. 17) discloses two relatively distinct groups of stones: 1) those to the north near test pit \#4, and 2) a southern group. Six test pits were excavated, encountering historic occupational debris down to $30 \mathrm{~cm}$ below the surface.

To search further for architectural remains, the ground surface was swept with a broom in suspected areas to clear the ground of vegetational debris and expose any features. An area of ground was swept revealing the only known intact architectural remains at the site, in the southeast corner of the site. These remains (Fig. 18) are a single course of aligned sandstone slabs which are buried only a few 


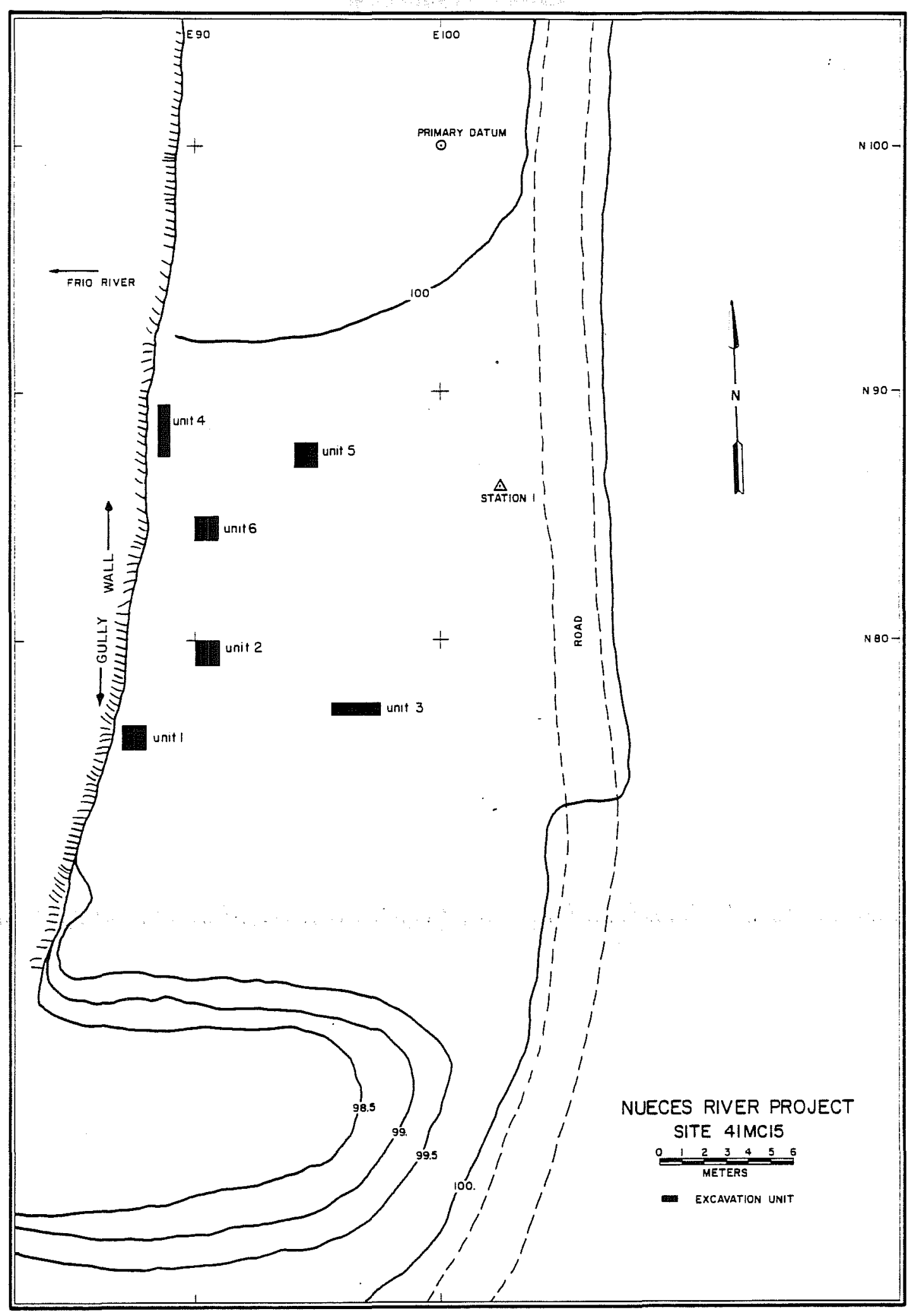

Figure 16. Site Map of 47MC15. 


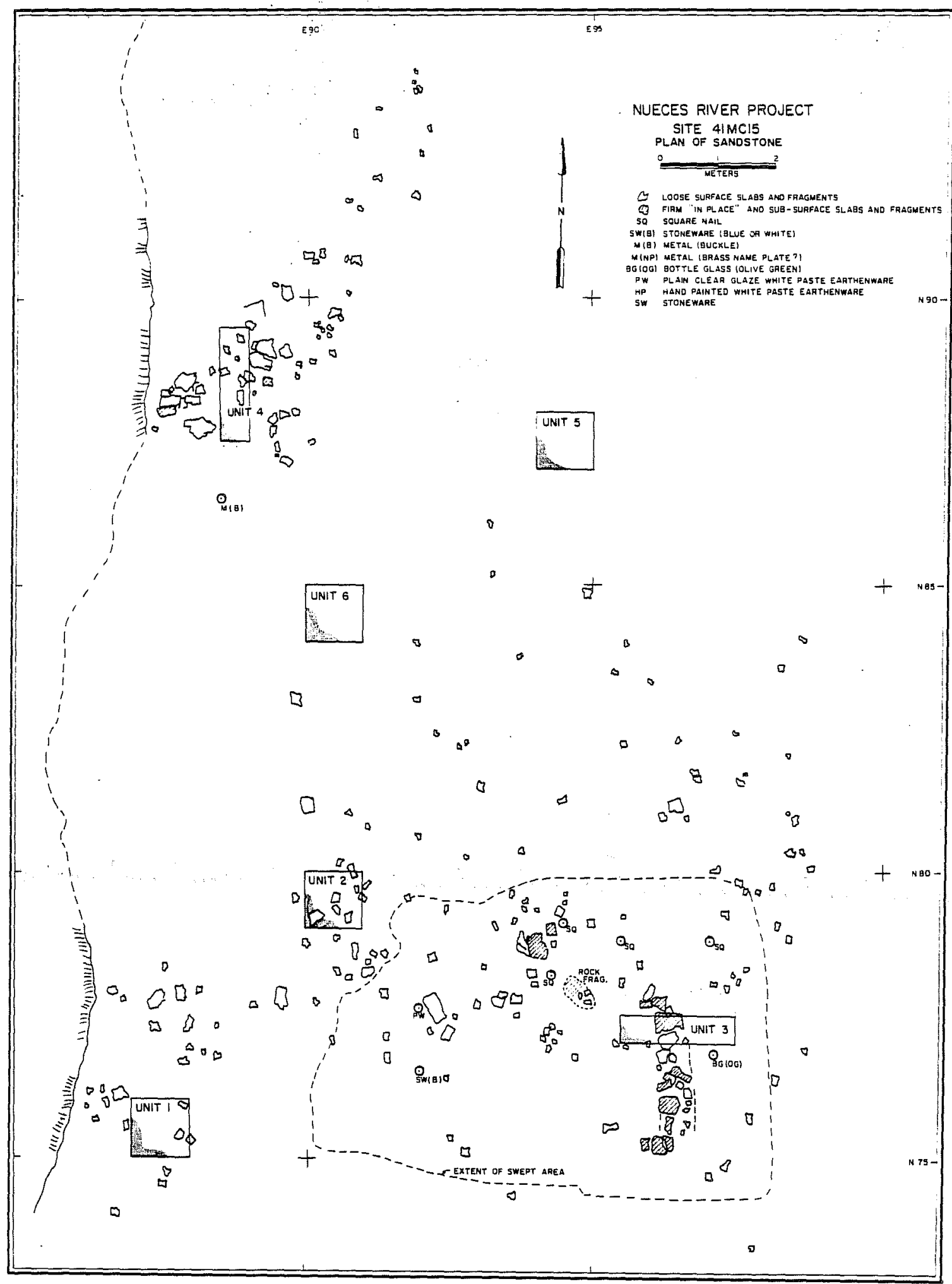

Figure 17. Plan Map of Sandstone, 41MC15. 


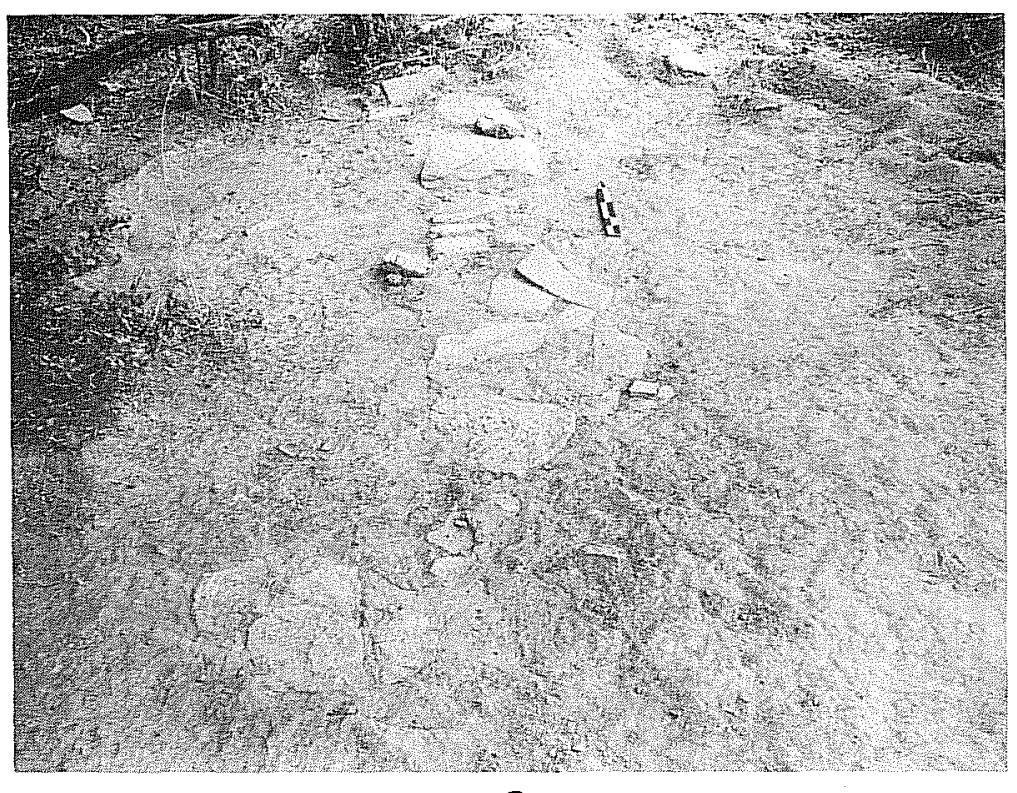

a

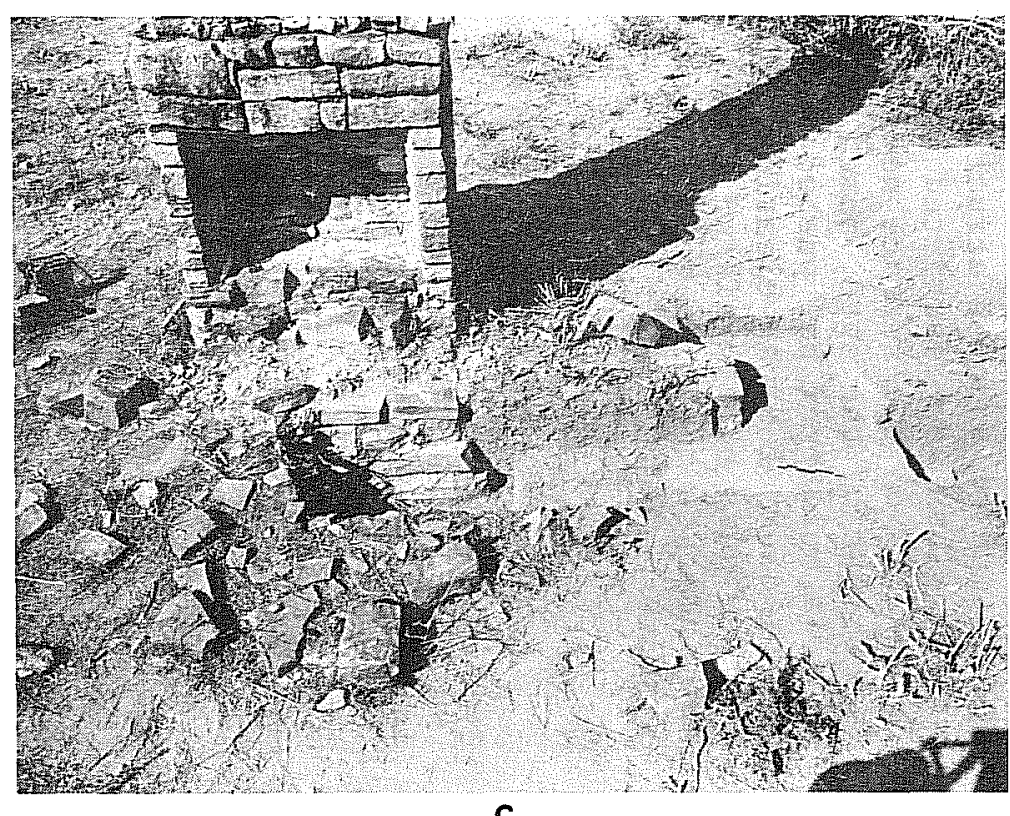

C

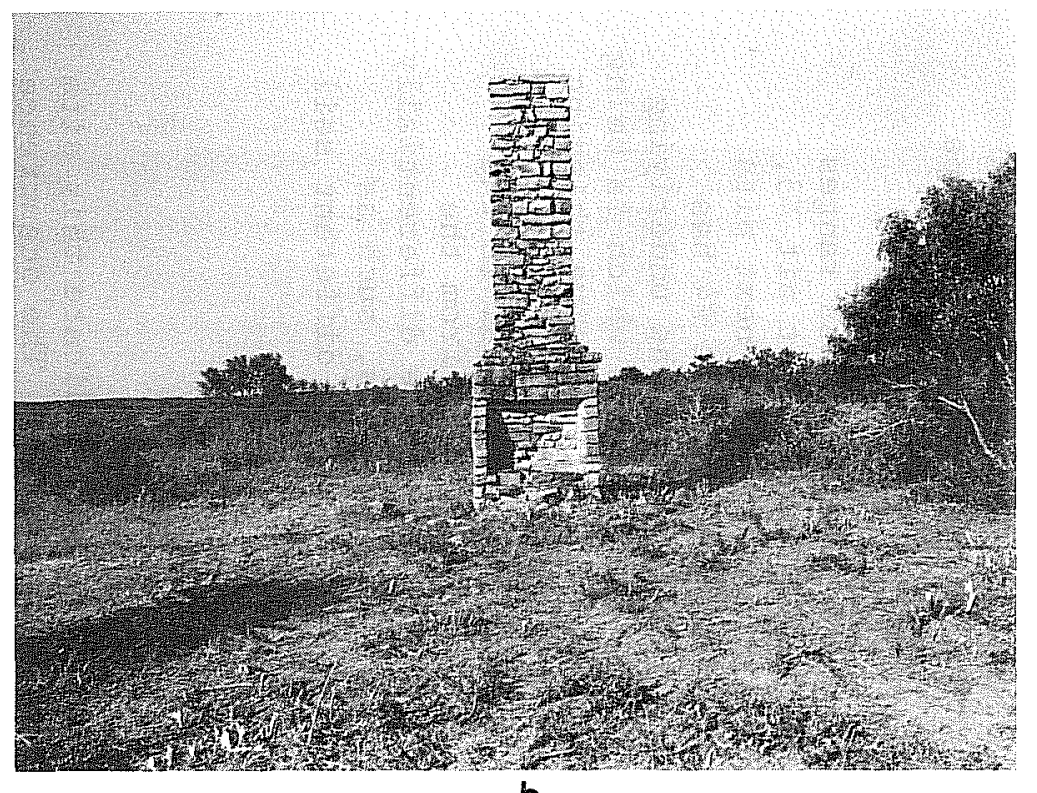

b

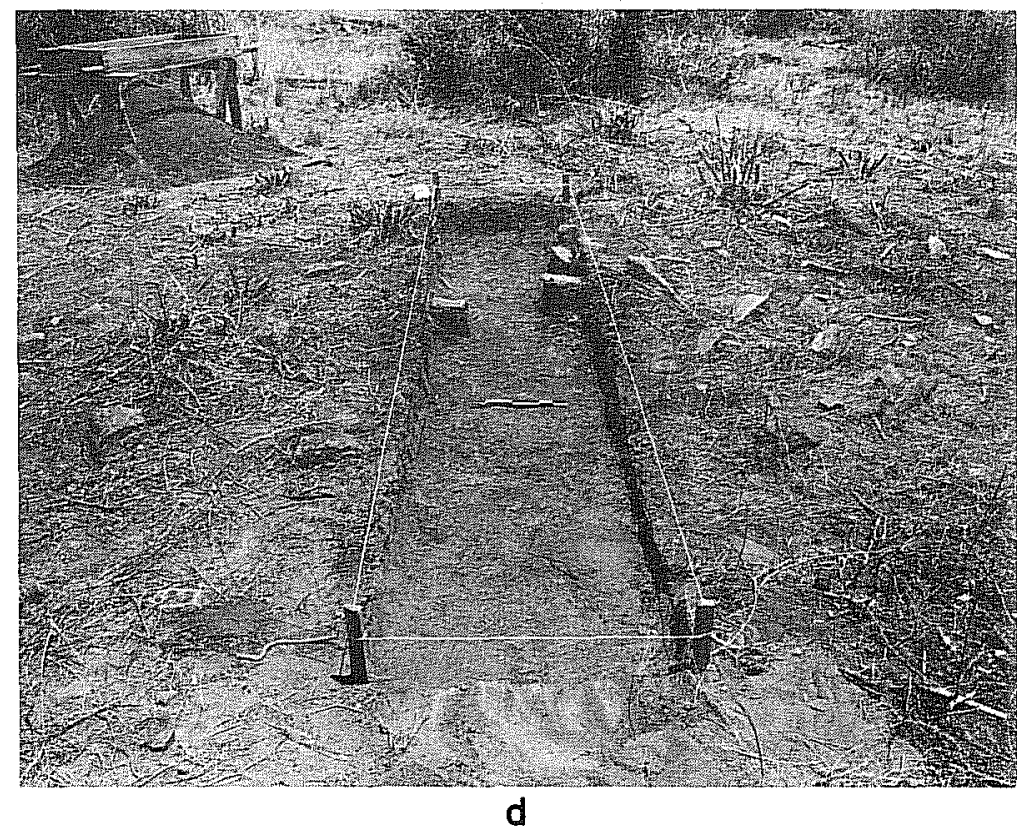

Figure 18. Photographs of Various Features. a, sandstone slab alignment, 41MC15; b, sandstone house chimney, 41MC17; c, scattered sandstone rocks and test pits $\#_{1} 1$ and $\#_{3}$ in front of chimney; $d$, test trench \#1, 41 IMC74. 
centimeters below the surface. Test pit 3 confirmed the shallow nature of the relatively undisturbed feature. Artifacts encountered during sweeping were carefully plotted on the plane table map. There are no associated architectural remains, and the occurrence of historic debris is restricted to the upper $10 \mathrm{~cm}$ of soil. The exact function of this slab alignment is unknown, but it is assumed to be some type of wall footing or foundation.

The distribution of historic artifacts in the test pits ranges from the surface down to $10 \mathrm{~cm}-30 \mathrm{~cm}$ below the surface. Test pit 非, as did test pit $k_{1} 1$, encountered debris only to $10 \mathrm{~cm}$. The next pits to the north encountered thicker deposits of $20 \mathrm{~cm}$, and pit 44 has nearly $30 \mathrm{~cm}$ of historic material-bearing soil. Most of the underlying soils contain prehistoric, aboriginal occupational debris which is being tested and evaluated by the UTSA field crews. The progressive thinning of deposits to the south is due most probably to surface erosion being more extensive to the south end of the site and the material in the northern end actually being filled in, perhaps with soil from the southern end of the site. The historic deposits could be differentially deposited, but there is no discernible indication of this, such as soil color change or texture difference; only a slightly different soil compaction was noted.

\section{Artifacts}

The recovered archeological materials (Table 7) indicate this site to be a habitation site of mid-19th century occupation. The occurrence of ceramic dishes, glass bottles, and tin can fragments indicates the use of the site for habitation. Nails are relatively common and are indicative of a house structure, as is window glass. The occurrence of window glass was restricted mostly to the first level of test pit $k^{4}$. The debris on the surface near test pit $\|_{4} 4$ is thought to be from some other part of the site, based on its appearance as a "site." It looks as if a bulldozer had pushed this debris along the ground surface in the process of brush clearing and left the pile by backing up to make another pass or by raising the blade. The occurrence of window glass may indicate the pile to be associated with the location of a (second?) structure.

\section{Chronology}

The datable artifacts (Tables $8 \mathrm{~b}, 9$ ) indicate the site to date between the $1850 \mathrm{~s}$ and 1900 . 
$41 \mathrm{MC17}$ (Surface Collection and Intensive Testing)

\section{Description}

This site (Fig. 19) has the most complete older architectural remains in the western part of the reservoir. A wel1-preserved sandstone chimney (Fig. 18, b), scattered sandstone rocks and various historic occupational debris are evident on the surface in an area about $25 \mathrm{~m} \times 30 \mathrm{~m}$. Situated about $100 \mathrm{~m}$ south of the Frio River on a high terrace and slight rise, the site has been damaged by brush clearing except adjacent to and including the chimney. No definite architectural remains were found in association with the chimney. On the north side of the chimney was a group of sandstone slabs (Fig. 18, c) one course thick (on the surface), which could have been a feature similar to that in site 41MC15 (Fig. 18, a). It was not tested.

Four test pits (Fig. 20) were placed in positions where walls, post molds, footing trenches, or other architectural features could be expected, but except for some disturbances which are probably rodent burrows, no such features were encountered. All historic artifacts were buried shallowly. The area around the chimney has been cleared several times, and one large pile of dirt and debris is the result of

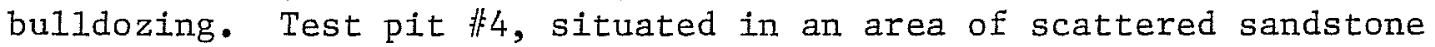
blocks, revealed that these rocks are all surface scatter. This evidence all indicates that the site, except for the chimney itself, has been extensively disturbed by clearing and most if not all other architecture destroyed.

Excavations encountered prehistoric debris in all areas. This site component was sampled and extensively tested by the UTSA field crew.

The stone chimney is constructed of shaped sandstone blocks mortared with lime mortar. The foundation (Fig. 2I) extends about $36 \mathrm{~m}$ below what may have been the ground surface at time of construction and is set on a $4 \mathrm{~cm}$ thick layer of lime mortar. If the chimney foundation was constructed symmetrically with the stack, the total dimensions would be about $2 \mathrm{~m}^{2}$. The chimney (Fig. 18, b) stands $5.25 \mathrm{~m}$ tall and is braced in the top or mantel of the hearth with a flat piece of iron which is apparently a straightened piece of wagon wheel rim. This metal piece is beveled on both edges of one side, is perforated with a hole every $62 \mathrm{~cm}$ along its length, and measures $1.5 \mathrm{~cm} \mathrm{x} 6 \mathrm{~cm}$ in cross section. Part of the metal brace is visible in the upper left corner of the hearth opening as shown in Figure 18, c.

\section{Artifacts}

An extensively controlled artifact collection was made at this site (Table 7). Items recovered indicate the site to be a mid-19th 


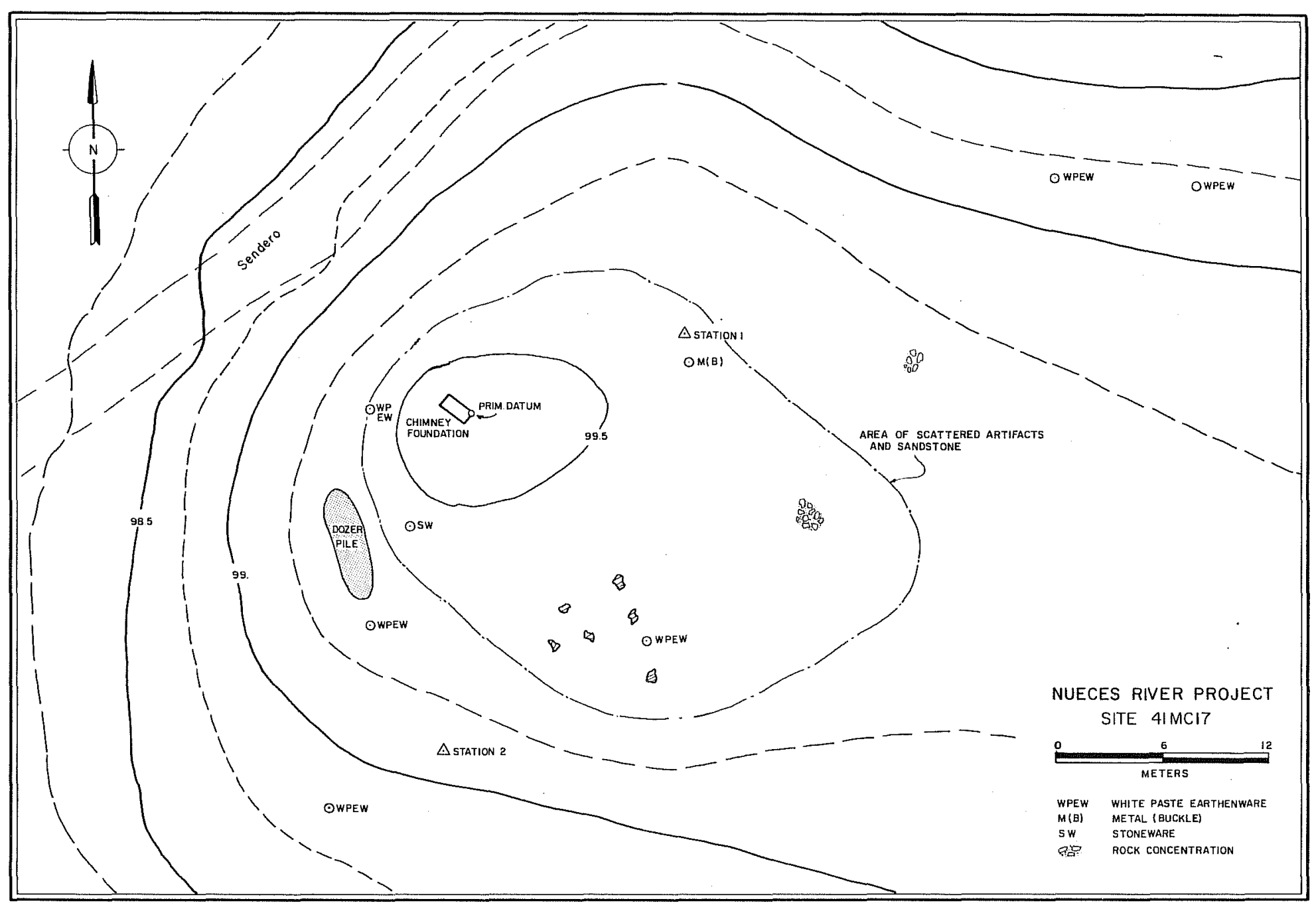

Figure 19. Site Map of $41 \mathrm{MC} 17$. 


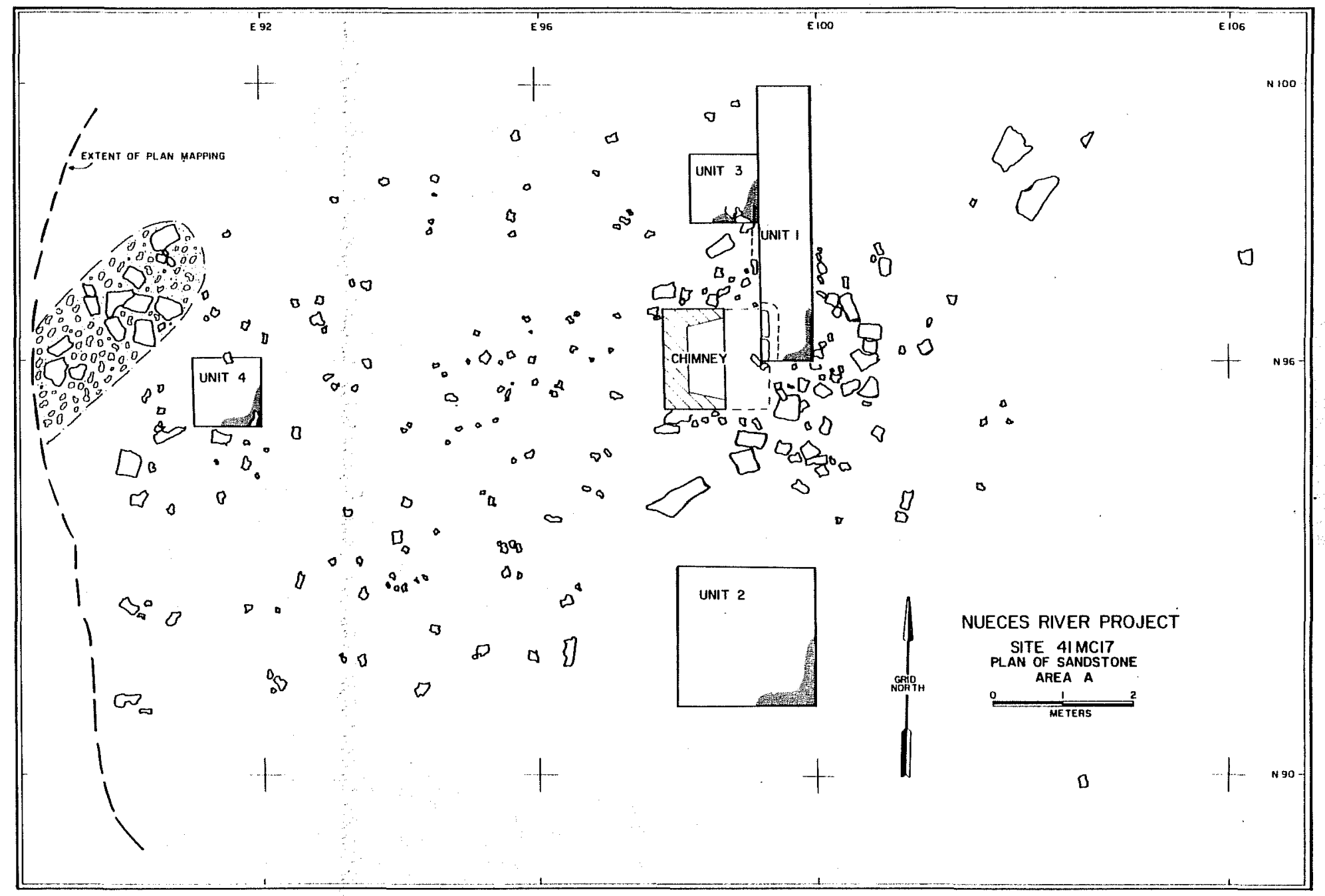

Figure 20. Plan of Sandstone and Excavation Units, Area A, 41MC17. 
century habitation. The presence of nails (Table 9), some of which are relatively large, indicate a habitation structure with large-sized lumber construction. Window glass was recovered in two test pits, also indicating the presence of a house. The ceramics and glass are, in general, like that found in the other project sites. One unique metal artifact was thought to be a chamber pot cover (Fig. 11, e). Constructed from molded sheet metal, the can has two hinged tops that fit one on. top of the other; the top one is solid and the second one has a large pear-shaped hole in it. The article is made without a bottom.

\section{Chronology}

The artifacts in general date from the last half of the 19 th century (Table 8c). The exclusive occurrence (except for one fragmentary specimen of what might have been a wire nail) of square cut nails dates the site to pre-1890-1900. Although several maker marked sherds were recovered, these were not identifiable. The manufacture of bottles went through several distinct stages which allow for relatively accurate dating of specimens, particularly bottle rims (Lynn, Fox and o'Malley 1977:197), but the incompleteness of nearly all specimens prohibits more accurate dating. One bottle with applied lip (Fig. 11, c) is dated in the mid to late 19th century. Several items are of recent age, such as the Schlitz beer can and the foil packets; because the chimney is still standing, the locality attracts picnickers and visitors.

MC17 exhibited several ammunition cartridges (Fig. 11, f-p) which were produced primarily in the late 1800s. Two .44 Henry Flats, introduced in the late 1860s (Logan 1959:68), are probably the oldest cartridges examined. A .41 Short, introduced with the National Arms Co. breech-loading Derringer in 1863, was another of the older cartridges. Several pocket revolvers were chambered for the .41 Short, but it has been obsolete since World War II. A .44 caliber W.C.F., commonly called the .44-40, was introduced in 1873. This specimen used the balloon head primer which was not made after 1930 (Logan 1959:137). The latest cartridge for this site is a .44 Short. This cartridge, chambered in many popular pistols and revolvers, was well established by 1870, but obsolete by 1920 (Barnes 1972:279).

\section{MC46 (Surface Collection and Mapping)}

\section{Description}

Site 41 MC46 (Fig. 22), situated on a small knoll about $30 \mathrm{~m}$ from Opossum Creek, is a scattering of sandstone blocks, under which are wall alignments, a chimney foundation and associated historic occupational debris. The outline shape of the house is discernible from a single course of aligned slabs. The slabs are clearly visible along the west edge of the structure and up to the chimney, which is set slightly into 


\section{NUECES RIVER PROJECT \\ SITE $41 \mathrm{MCI} 7$ \\ EAST PROFILE UNIT I \\ AND CHIMNEY PLAN

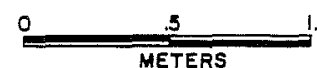

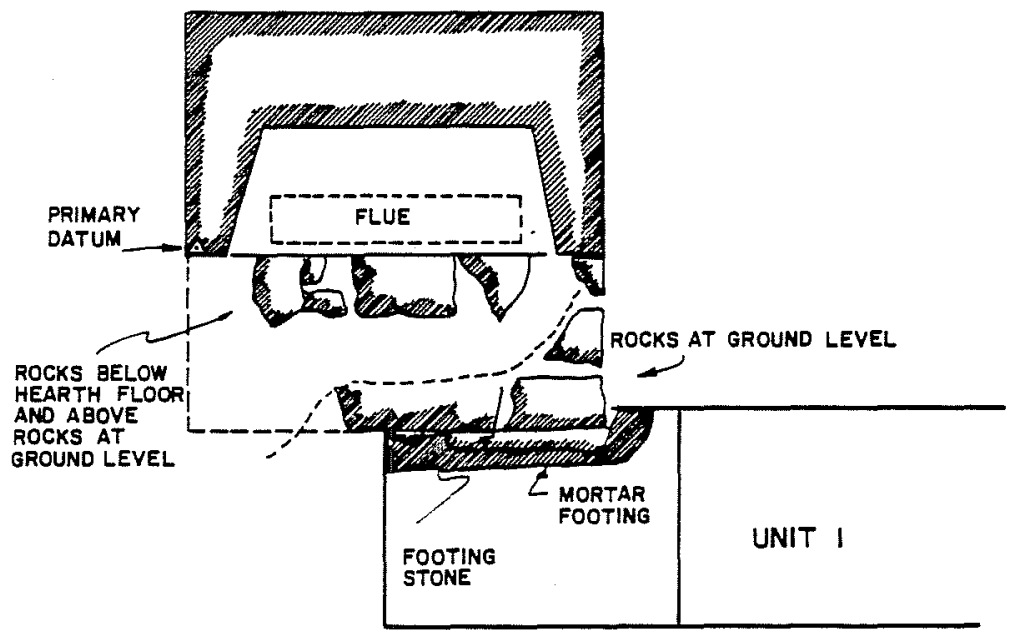

GRIO NORTH

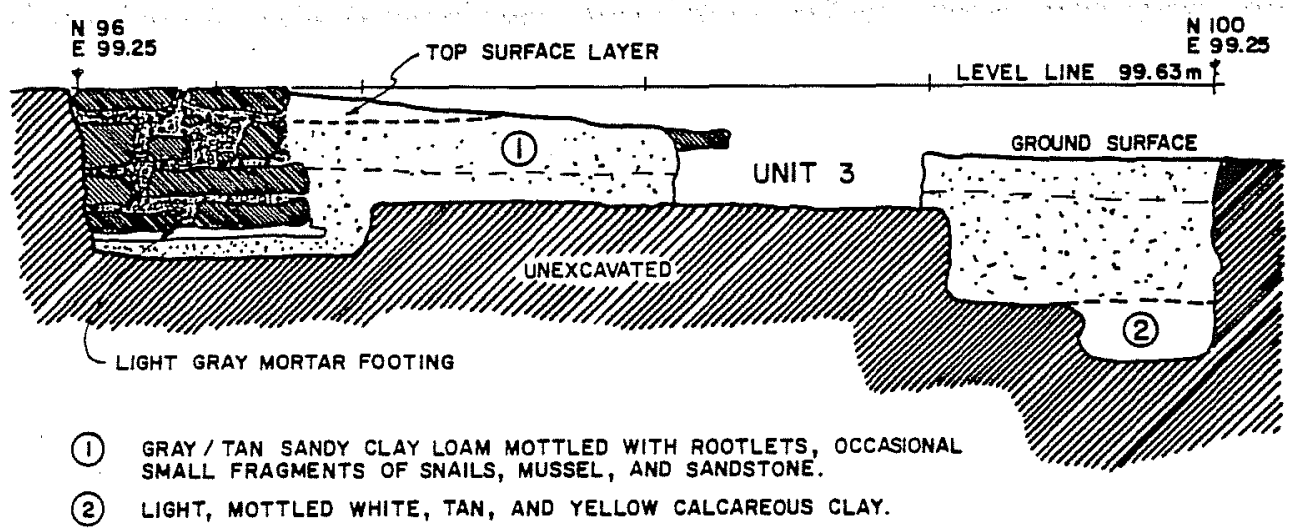

Figure 21. Details of East Profile Unit 1 and Chimney Plan, $41 \mathrm{MC} 17$. 


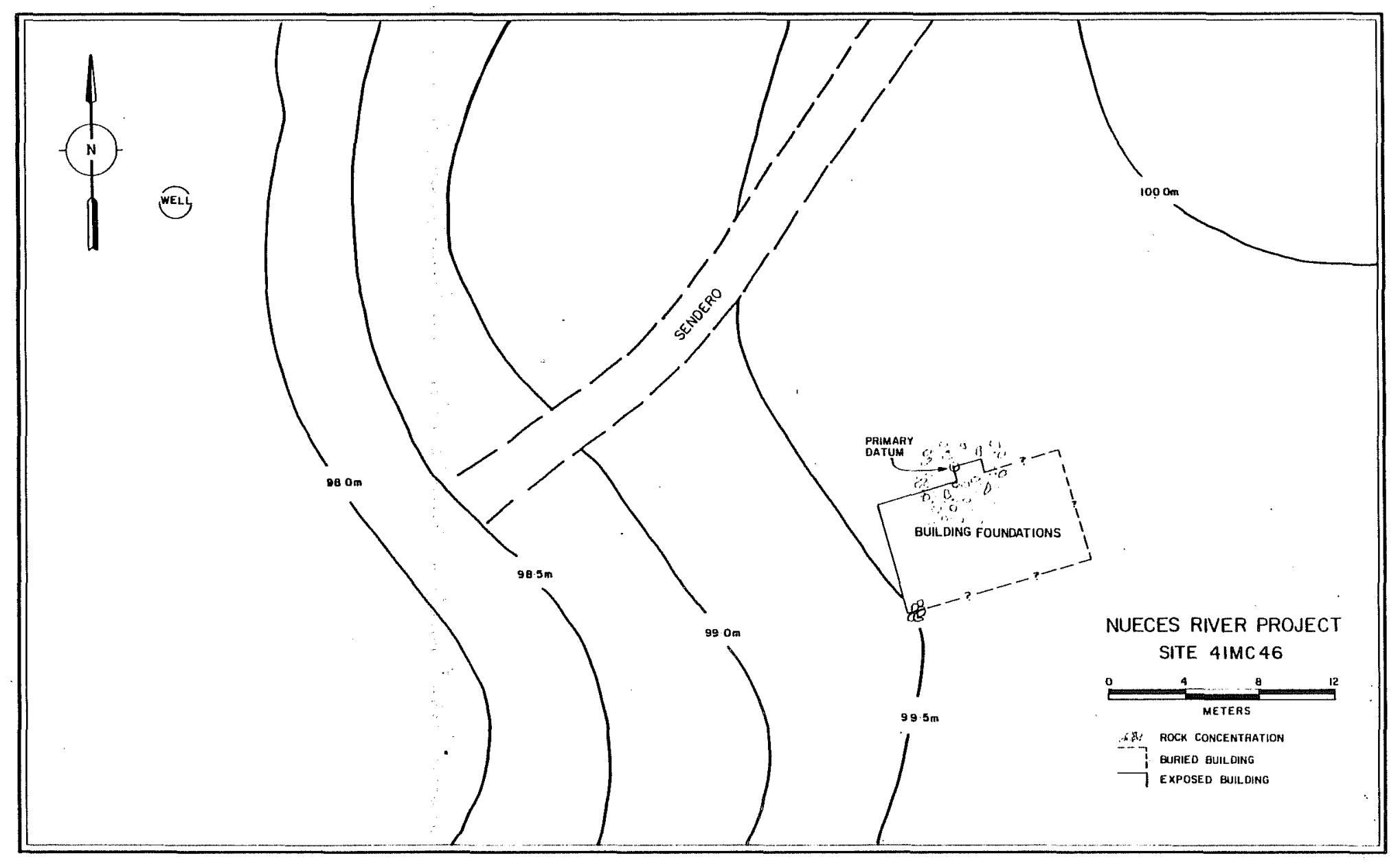

Figure 22. Site Map of $41 M \mathrm{MC}_{4} 6$. 
the house. The chimney was apparently all of sandstone and collapsed into the interior of the house. There are scattered slabs and rocks over the entire house area, some of which are remnants displaced from the other walls of the structure. The site may be damaged from clearing, but subsurface excavations were not conducted to confirm the extent of damage and what portions of the structure remain.

Associated architectural remains include the collapsed chimney, chimney foundation, wall footing slabs, and a well. The well is located 44m west-northwest from the center of the chimney foundation and is about $1.6 \mathrm{~m}$ in diameter and of an undetermined ( $3+\mathrm{m}$ ?) depth. The well is cut into a sandstone formation and had standing water in it at the time of the field work. The shaped stone and mortar chimney with a single course of very shallow to ground surface sandstone slab alignment are consistent elements of the Yarbrough Bend architecture. The presence of the wall footing slabs may explain in part why no foot trenches have been encountered to date, but the exact relationship of these slabs to the rest of the walls is still unknown.

\section{Artifacts}

The artifacts from this site (Table 7) were gathered as a general sample and indicate the site to be probably a late 19 th century habitation site (Table $8 \mathrm{~d}$ ). There is an absence of square cut nails, but there was clearly a house at the site. The collecting methodology and the thick grass cover at the site may be responsible for this absence. The absence of many decorated ceramic sherds is perhaps indicative of "no frills" subsistence. The relative abundance of ceramic dishes and stove parts, and absence of bottle glass and tin cans, indicates that the house was not lived in for a very long period of time, and that it was abandoned with its contents, which were perhaps vandalized or discarded, but not moved and used later.

\section{Chronology}

One clear glass bottle base has the distinct circular scar indicative of manufacture by an Owens automatic bottle making machine, which dates the bottle after 1913 (Munsey 1970:249). Another attribute of the automatic machine made bottle is the extension of the side seams all the way to the top of the bottle and around the lip (Fig. 11, c c). These molded lip specimens also date post-1913.

A rectangular top portion of a tin can suggests it is possibly the tapered "corned beef" type which started about 1875 (Fontana and Greenleaf 1962:73). Also, a ceramic sherd with a partial maker mark has two possibilities. It is probably Bridgewood and Clarke, since other marks by this maker have been examined. This would date 1857 to 1864 (Godden 1964:101). The alternate possibility is Edward Clarke, formerly Bridgewood and Clarke, which operated from 1865 through 1887 (Godden 1964:147). 
41MC72, "New" Site (Surface Collection and Intensive Testing)

\section{Description}

This site (Fig. 23) is composed of mainly a sandstone block concentration, and thinly scattered historic occupational debris. The rock concentration is apparently a collapsed chimney; no foundation was located. A test pit encountered a soil change at about $15 \mathrm{~cm}$ below the surface and a marked decrease of historic artifacts. The site has been extensively disturbed by clearing, is relatively shallow, and has no distinct architectural features visible from the surface. The site, discovered by the Texas Tech field crew in 1977, has not been previously reported. Located on the extreme edge of the terrace overlooking the Frio River, behind a barbed wire fence, the heavily overgrown site is hard to see even when immediately adjacent to it. There is virtually no artifactual material visible in the road and fence area, and heavy grass and brush growth beyond the fence on the site mask the other materials.

\section{Artifacts}

The site, based upon the artifact types recovered (Table 7), is a mid or late 19 th century habitation locality. There was a structure, as indicated by the nails (Table 9) and window glass. The area immediately downhill from the structure is heavily eroded and is the area where most of the habitation trash was probably discarded, thereby removing much of this particular class of debris. There were not very many items recovered, making relative frequencies of items less significant, but there is a distinctly low frequency of decorated ceramics. Similar to other sites (specifically 41MC46), the site occupants may have had a "no frills" family economy.

\section{Chronology}

The temporal placement of the site is late 19 th century. The datable items in Table $8 e$ are various and cover a broad time period.

One fragmented ceramic sherd with maker mark (Fig. 6, i) probably represents J. W. Pankhurst and Co. of Hanley, England, which operated from 1850 through 1882 (Godden 1964:481). Also, a marked glass sherd is present indicating post-1860 manufacture.

41MC74 (Surface Collection and Intensive Testing)

\section{Description}

This site (Fig. 24) represents what was probably another typical late 19 th century house structure, but extensive brush clearing and 


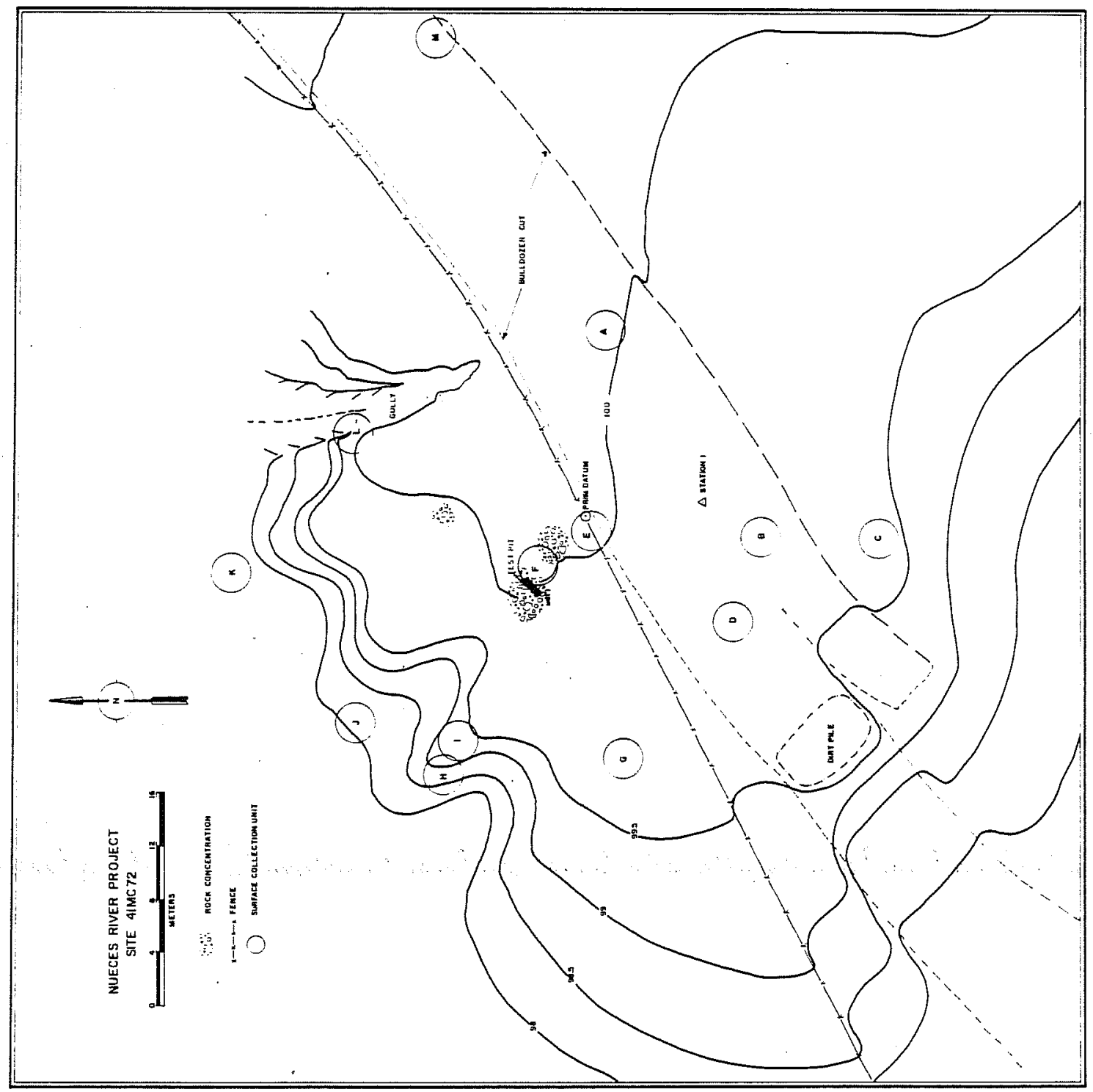

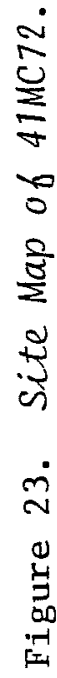




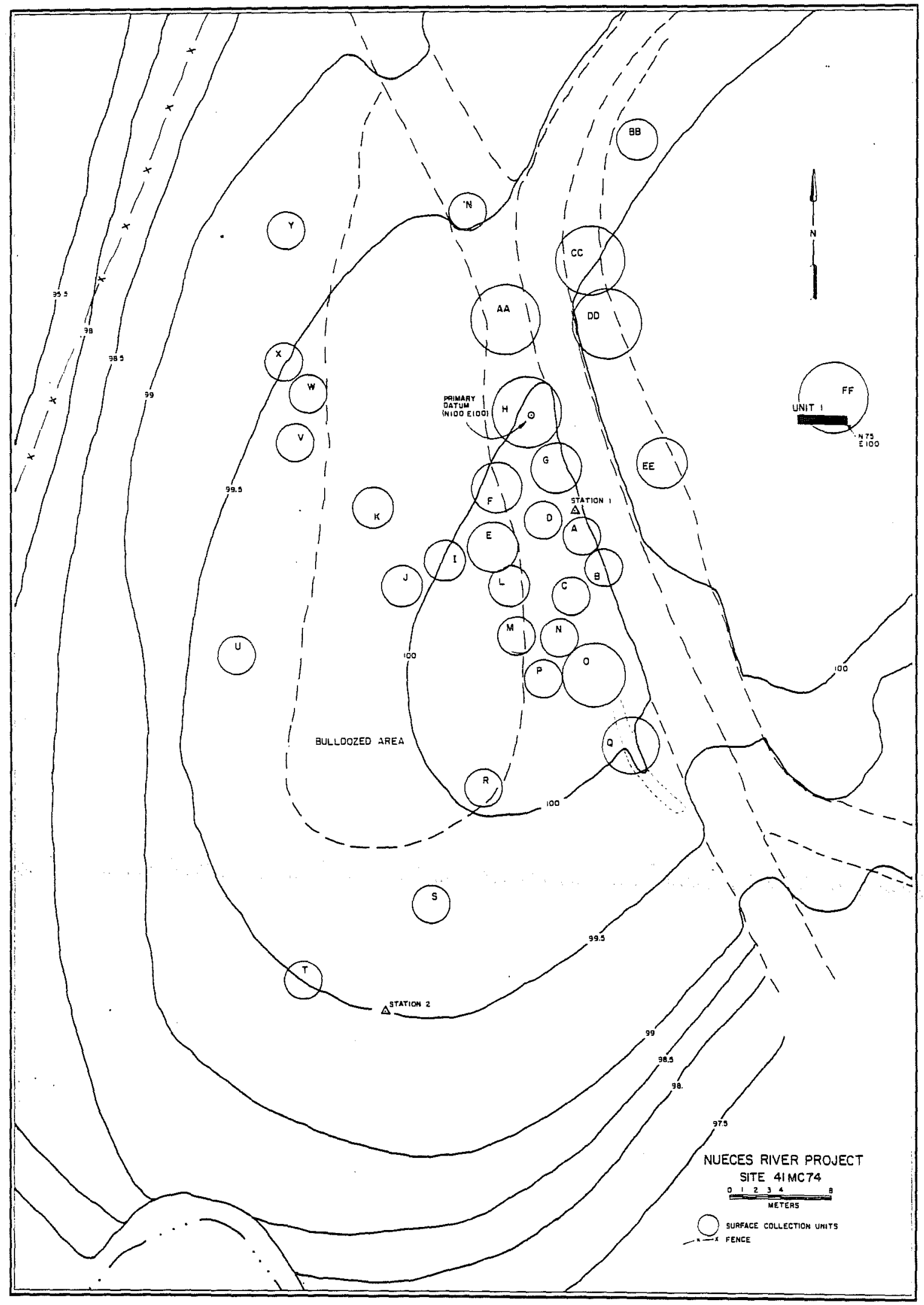

Figure 24. Site Map of $47 M C 74$. 
a road cutting through the middle of the site have destroyed most if not all of the structural remains. Scattered sandstone and historic occupational debris cover an area $40 \mathrm{~m} \times 60 \mathrm{~m}$ on a hill near the Frio River, with concentrations of materials eroding from numerous dirt ridges and piles pushed up by bulldozers. Test pit 非 (Fig, 18, d) was put in an area where possible house remains were located. The $.75 \mathrm{~m} \times 4 \mathrm{~m}$ pit was excavated to $10 \mathrm{~cm}$ below the ground surface at the southwest corner stake, and allowed the recovery of various historic artifacts, mostly in the upper $3 \mathrm{~cm}$ of the level.

The historic artifacts scattered on the surface were fairly profuse, due mainly to the recently "filled" nature of the disturbances. These artifacts were collected in a series of collection circles of various sizes ranging from $1.5 \mathrm{~m}$ to $2.5 \mathrm{~m}$ in diameter, and situated where artifact concentrations were found. The central point of each surface collection circle was mapped with the plane table/alidade and drawn on a site overlay. The overlay was joined with the topographic map as shown in Fig. 24, and each was designated alphabetically by a letter.

\section{Artifacts}

The recovered artifacts (Table 7) indicate the site to be a mid-19th century habitation site. The wide variety and great quantity of material is due probably to the highly disturbed nature of the site. The common occurrence of square cut nails (Table 9), some of which are fairly large ( $\left.3^{\prime \prime}\right)$, indicates a fairly large structure with heavy lumber construction. There are a few window glass sherds scattered over the site as well. The amount of materials that could be associated with habitation (trash) relative to the amount of material associated with a structure (construction and architecture) appears to be rather high in comparison to other sites. An in-depth and quantitative comparison is not possible within the scope of this project, but apparently some sites such as 41MC74 were inhabited for much longer periods of time than other sites such as 41MC46. It may be possible to construct a habitation index based upon some quantifiable criterion such as food container vs. shelter debris.

\section{Chronology}

Numerous artifacts were recovered with a distinct temporal significance (Table 8f). In ceramic ware there are embossed rims dating to the mid to late 19th century. Glass items include applied lips on bottles and fruit jars. A few wire nails were recovered, but the vast majority are square cut, indicating abandonment of the site by the 20 th century.

The dates for MC74 are indicated by several ceramic sherds with maker marks. One sherd with the impressed Davenport mark of the 
Staffordshire Potteries in England includes the last two numerals of the year, which are placed on each side of the anchor insignia (Godden 1964:189). These numerals indicate that this piece was made in 1856. A second ceramic sherd shows the W. Baker and Co. mark of Fenton, England (Godden 1964:51). This mark includes a diamond-shaped symbol which occurs on Victorian ceramics from 1842 to 1883 . This was used to date the registration of the maker mark at the Patent Office in London. The letters and numbers were arranged in two different ways around the diamond symbol. From 1842 to 1867 the year letter appears in the top panel. From 1868 to 1883 the year letter appears in the right-hand panel (Godden 1964:526-7). Although the top panel of the specimen is obscure, the bottom panel is identifiable. The bottom panel, according to the two identification schemes, can have either a number representing the parcel or a letter representing the month. This specimen shows the number in the bottom panel, representing the parcel number, and indicating this piece was of 1842-1867 registration design. The third ceramic sherd with a maker mark (Fig. 6, h) is one produced by Bridgewood and Clarke of Burslem, England from 1857 to 1864 (Godden 1964:101). One glass marked panel sherd which was produced after 1860 is present in the collection.

41MC91 (Surface Collection and Mapping)

\section{Description}

This site (Fig. 25) has an extant frame house (Fig. 26, a) with associated scatter of historic occupational debris, water cistern or tank (Figs. 26, b; 27). The site is situated on a ridge top on the edge of the valley wall. The site is $30 \mathrm{~m}$ from the old river bed of San Miguel Creek, which is presently about $700 \mathrm{~m}$ to the south. Original investigations by THC questioned the antiquity of the extant house and noted the incongruence of its suspected post-1900 age relative to the late 19 th century age of the site as suggested by the artifacts. A chimney foundation remnant, feature 1, was discovered eroding in the road bed in front of the extant structure, indicating the presence of an earlier structure and explaining the earlier incongruence problem. A second sandstone block concentration was noted to the NE of the extant house but is of an undetermined nature. Square cut nails were found in association with this concentration (on the south side), indicating perhaps an outbuilding in association with the earlier 19 th century occupation.

A circular stone tank or cistern (Fig. 26, b) was found between the extant house and an associated shed, but the exact relationship of this feature is unknown. The feature is $1.8 \mathrm{~m}$ in diameter, is filled with rocks and dirt, and is flush with the ground surface. The location of this feature is next to the corner of the extant house and could conceivably be associated with this house, but it is also close enough to the chimney foundation that it could be associated with the earlier structure. 


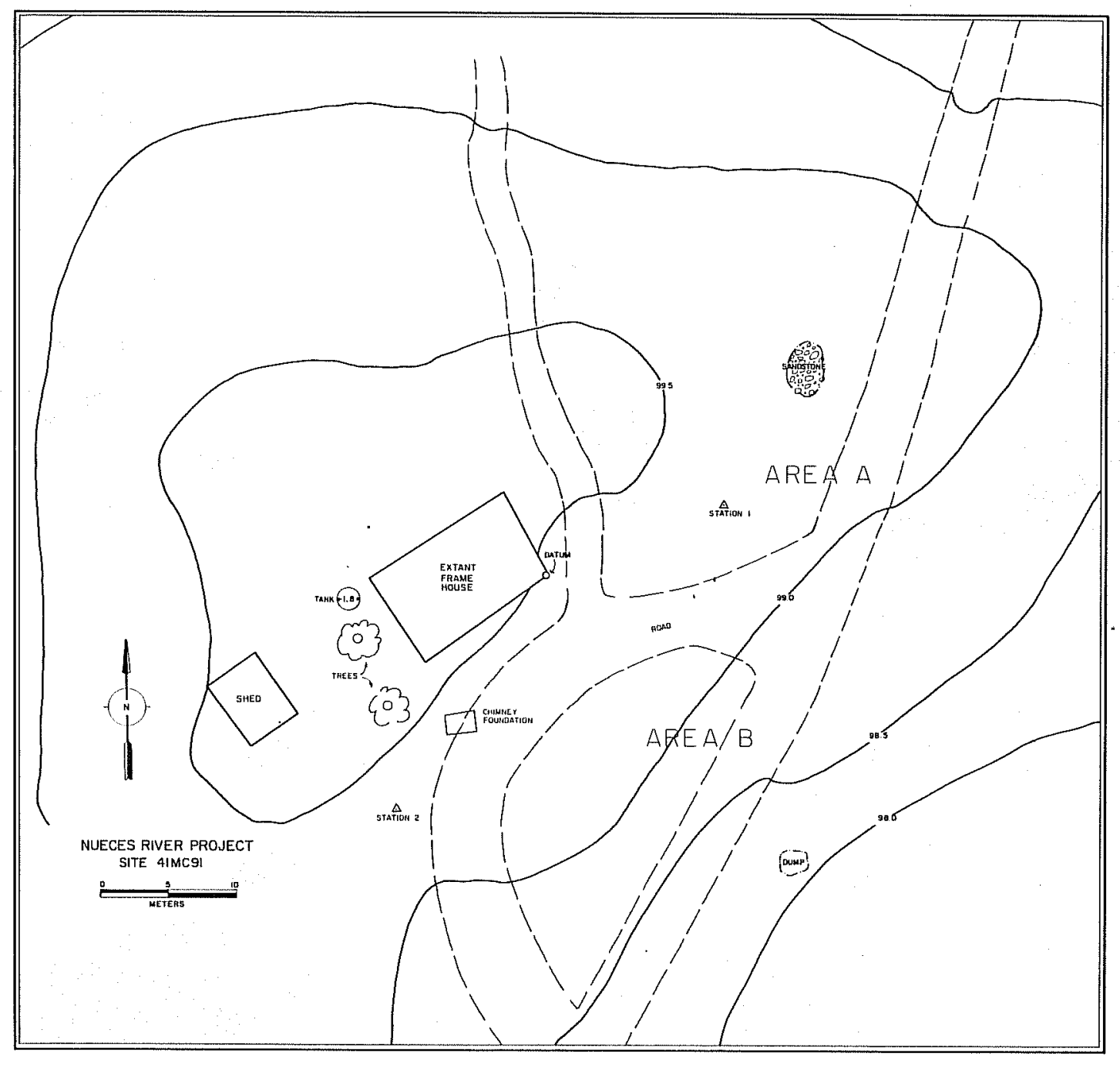

Figure 25. Site Map of 41MC91. 

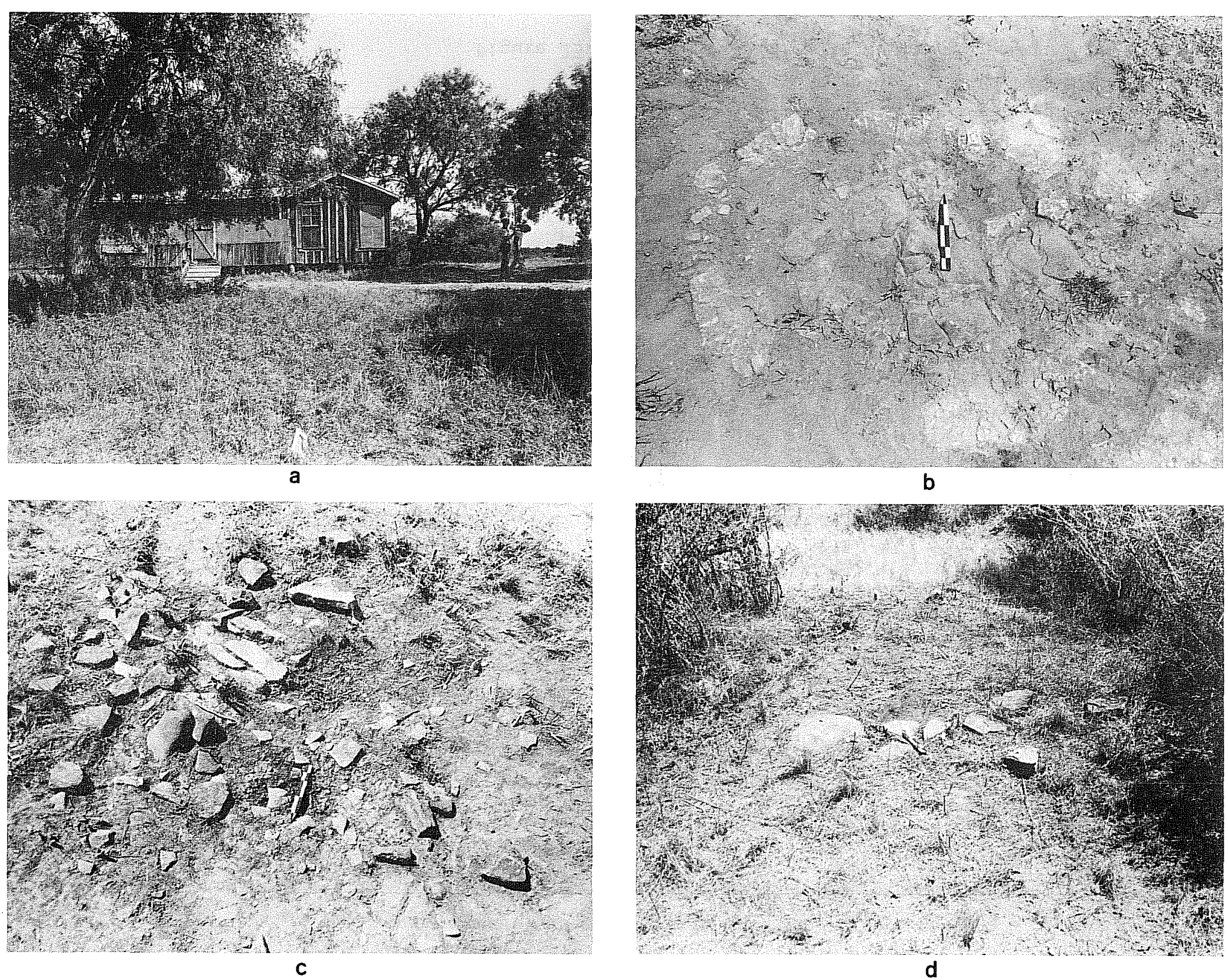

Figure 26. Photographic Views of $41 \mathrm{MC} 91$ and 41MC185. a, extant house, 41MC91; b, cistern or tank top west of extant house, 41MC91; c, feature 1, badly disturbed chimney foundation, 41MC185; d, feature 2, 41 MC185. 


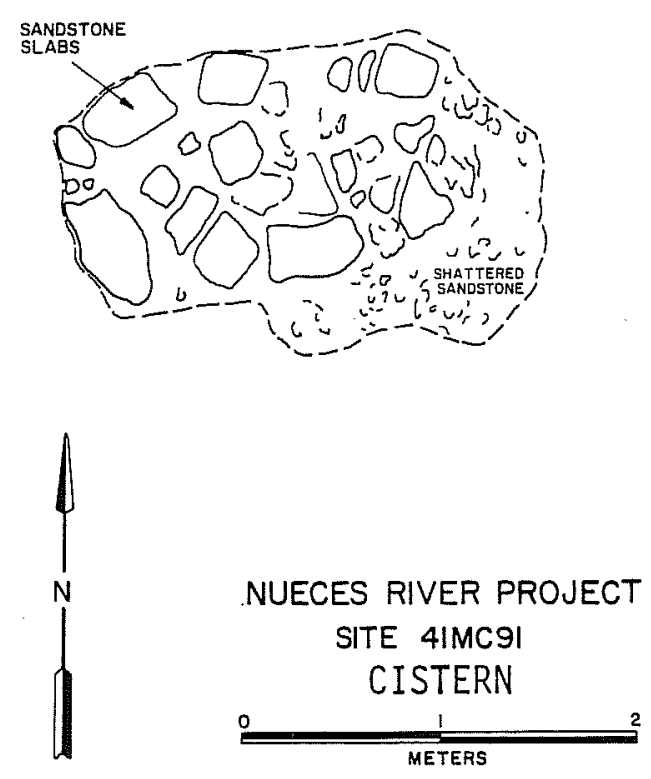


For the collection of surface artifacts, the site was bisected with a line running east from the SE corner of the extant house; the area to the north of this line and east from the house was designated as area $\mathrm{A}$, and the area to the south of this line and the house designated as area $B$,

\section{Artifacts}

Artifacts (Table 7) include a small amount of decorated ceramic ware, and a high occurrence of cartridges. The cartridges are recent items which are the result of the extant structure being used as a hunting cabin. The absence of decorated ceramics may be a function of the late chronological placement of the site.

\section{Chronology}

The site, based on datable artifacts (Table $8 \mathrm{~g}$ ), is probably no older than about 70-80 years. Built around the turn of the century, there is a high proportion of wire nails (Table 9), recent cartridges, such items as a battery post, copper tubing with a brass ferrule fitting, bright colored glass, and machine made bottles with molded 1ips. The applied bottle lips and square cut nails indicate a possible pre-1900 habitation of the site, possibly associated with an earlier structure. The exact age of the house itself cannot be ascertained at present.

Of the datable items from MC91, ammunition cartridges were quite prevalent. All cartridges are expended unless otherwise indicated. One .45 Colt, made by Western, was introduced in 1873 and is still popular today (Barnes 1972:172). The oldest cartridge from this site appears to be .44 caliber commonly referred to as a .44 Henry Flat. The .44 Henry Flat refers to the flat nose bullet, which is not present, but the case is of the same cartridge. F. Tyler Henry developed this large caliber for the 10,000 Henry repeating rifles produced from 1860-1866 (Logan 1959:68).

Two .32 caliber Smith and Wesson Longs, introduced in 1903, are present along with a .32 caliber auto, also introduced in 1903 (Barnes 1972:154). The $\cdot 30-30$ caliber Winchester found at the site was first marketed in 1895 for the Model 94 lever action rifle produced by Winchester (Barnes 1972:34). Also present is a.22 caliber long or long rifle cartridge which was developed in 1887 and is still very popular today (Barnes 1972:274). The distinction between the long and long rifle cartridge cannot be made since the case length is the same for each. 
41MC166, "Dump" Site (Surface Collection and Mapping)

Description

The site consists of scattered historic age artifacts and refuse. There is no evidence of structural remains, and the evident refuse may be the result of dumping. The site is situated about $20 \mathrm{~m}$ north of San Miguel Creek and covers an area of about $20 \mathrm{~m} \times 40 \mathrm{~m}$. The western portion of the site is heavily eroded by extensive gullying, and all the site is heavily overgrown with brush and grass. A general surface collection of specimens was accumulated, and no test excavations or maps were attempted.

\section{Artifacts}

The artifacts collected (Table 7) from this site indicated the site was probably a dump area. There is no evidence of a structure, and there is a low frequency of building related materials. Originaily identified as a durnp site by Lynn, Fox and 0'Malley (1977, Table 21), the site, if it is a dump, is somewhat of an anomaly; it is the only "dump" site in an era when each habitation site had its own dump immediately adjacent to the structure. The site is very heavily eroded, and it can be suggested that the site may be a habitation locality with the associated structure completely obliterated. The occurrence of nails and window glass tends to support this possibility.

\section{Chronology}

The items dated from MC166 (Table 8h) indicated a wide time span through the mid to late 19 th century. A single marked glass panel sherd appears in the collection, representing a date post-1860. Square cut nails (Table 9) represent mid to late 1800 s, and glass material into the late 1800 s and early 1900 s.

\section{MC168, Teal Site (Surface Collection and Mapping)}

\section{Description}

Discovered in the last few days of the field study, this site is reported after only a brief surface examination. The site covers a small area approximately 70m south of San Miguel Creek in the NN part of the previously reported prehistoric component of 41MC168. Consisting primarily of scattered historic occupational debris and sandstone, there is one probable rock house foundation, with a second rock concentration about 25-30m to the north and about 30m from San Miguel Creek. The site is disturbed by brush clearing, erosion, and animal burrowing, and is thickly overgrown with brush, grass, and cactus. No maps were made. 
Artifacts

The ceramics are all undecorated earthenware or stoneware. No window pane sherds were present, but four bottle bases made in a bottom hinged mold were recovered. The site is a habitation site, probably dating in the late 19th century. The occupants of the site were probably of lower socio-economic status based on the lack of decorated wares. More extensive investigations may corroborate this view. As can be seen in the inventory (Table 7), there is a prehistoric site component.

\section{Chronology}

The items encountered at this site (Tables $7,8 i, 9$ ) seem to represent the late 19 th century even though the glass bottle bottom hinged mold pattern spans from 1810 to 1880 (Fig. 28, b).

One ceramic sherd with a maker mark has two possibilities. Its fragmentary condition prevents any exact identification. The first possible maker is Clementson Bros. of the Staffordshire Potteries in Hanley, England which operated from 1865-1916 (Godden 1964:149). The second possible maker is Johnson Bros. also of Hanley, England who operated from 1883 (Godden 1964:355). Three aqua glass sherds show the Frederick Hampton Glass Works maker mark (Fig. 28, a). The "FHGW" mark appears on several types of handmade beer bottles-amber, and finished for corks, as found in western ghost towns (Toulouse 1971:202). This mark was used circa 1880 to 1900 . A fourth glass sherd with maker marks represents Burlington Glass Company. One of the oldest glass companies in Ontario, Burlington used its initials and sometimes its name in full on fruit jars (Toulouse 1971:85-86). The mark, "BGCo," was used from 1877 until 1909 when the company was taken over by the Diamond Glass Co. of Montrea1. One ammunition cartridge, a .45 Colt which has been in production since 1873 , is also present in the collection.

\section{MC175 (Surface Collection and Mapping)}

\section{Description}

The site (Fig. 29) is an extant wooden frame house structure with associated barn, outbuildings, corrals, fences, and scattered historic occupational debris. The site is situated on a point on the valley wall overlooking the Frio River $750 \mathrm{~m}$ to the west. Extant buildings include the house, a barn to the north of the house, a water tank/shed, and an outhouse or latrine. There is a dump area to the west of the house down the slope of the valley wall, and several remaining (standing) sections of fencing scattered in the area. One area fenced on the east side of the house and another to the south contain discarded wine bottles and trash. To the southwest of the house is a building foundation 


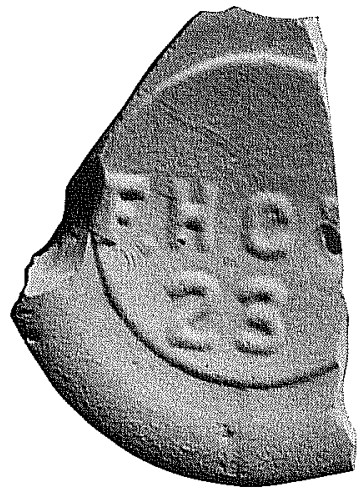

a
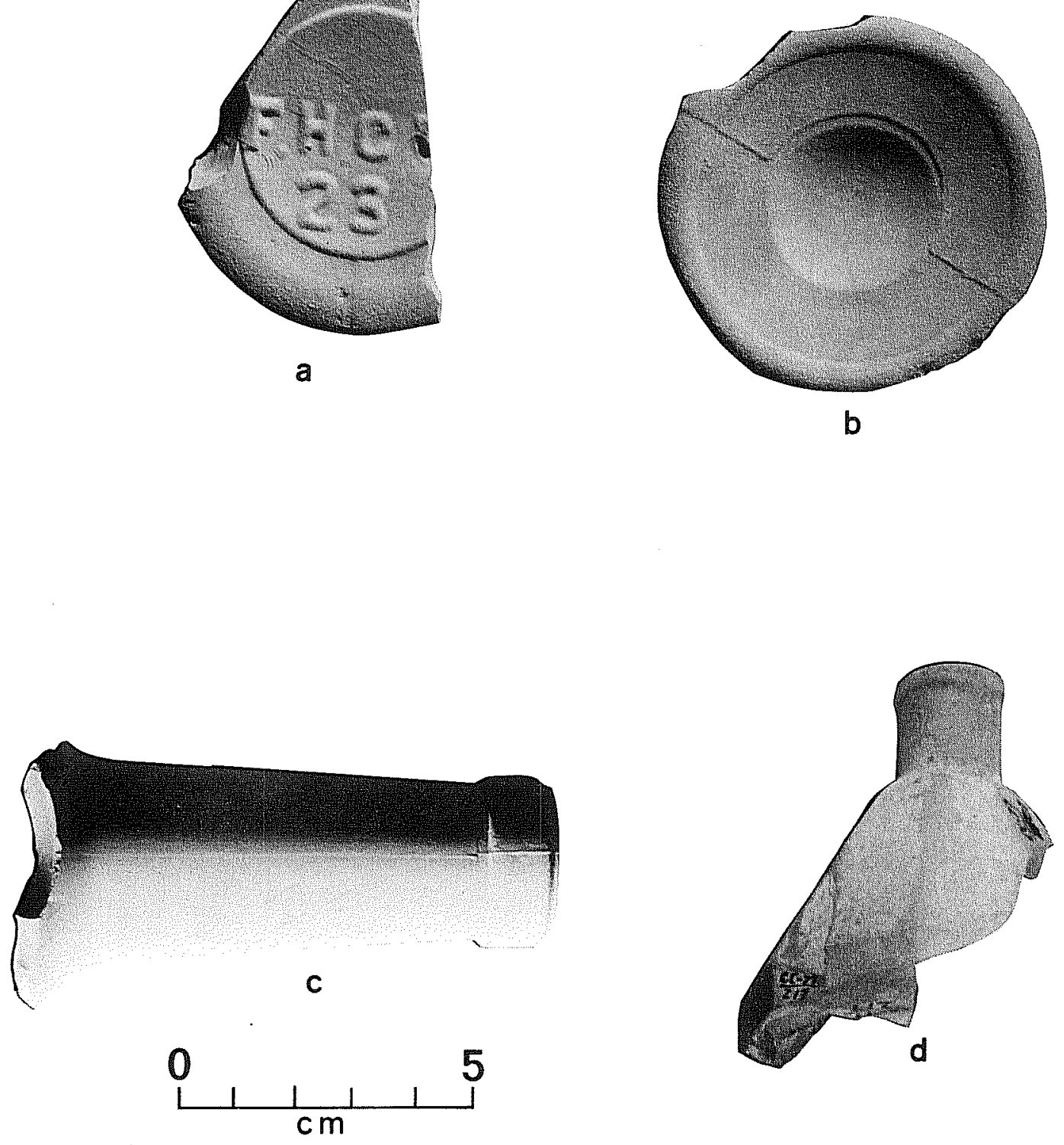

Figure 28. Artifacts from 47MC168 and 41MC192. a, bottle bottom with maker's mark and bottom hinged mold, 41MC168; b, bottle bottom with bottom hinged mold (unmarked), 41MC168; c, unidentified top of a bottle; d, ink bottle from 41MC192, has applied lip and made in a cup bottom mold. 


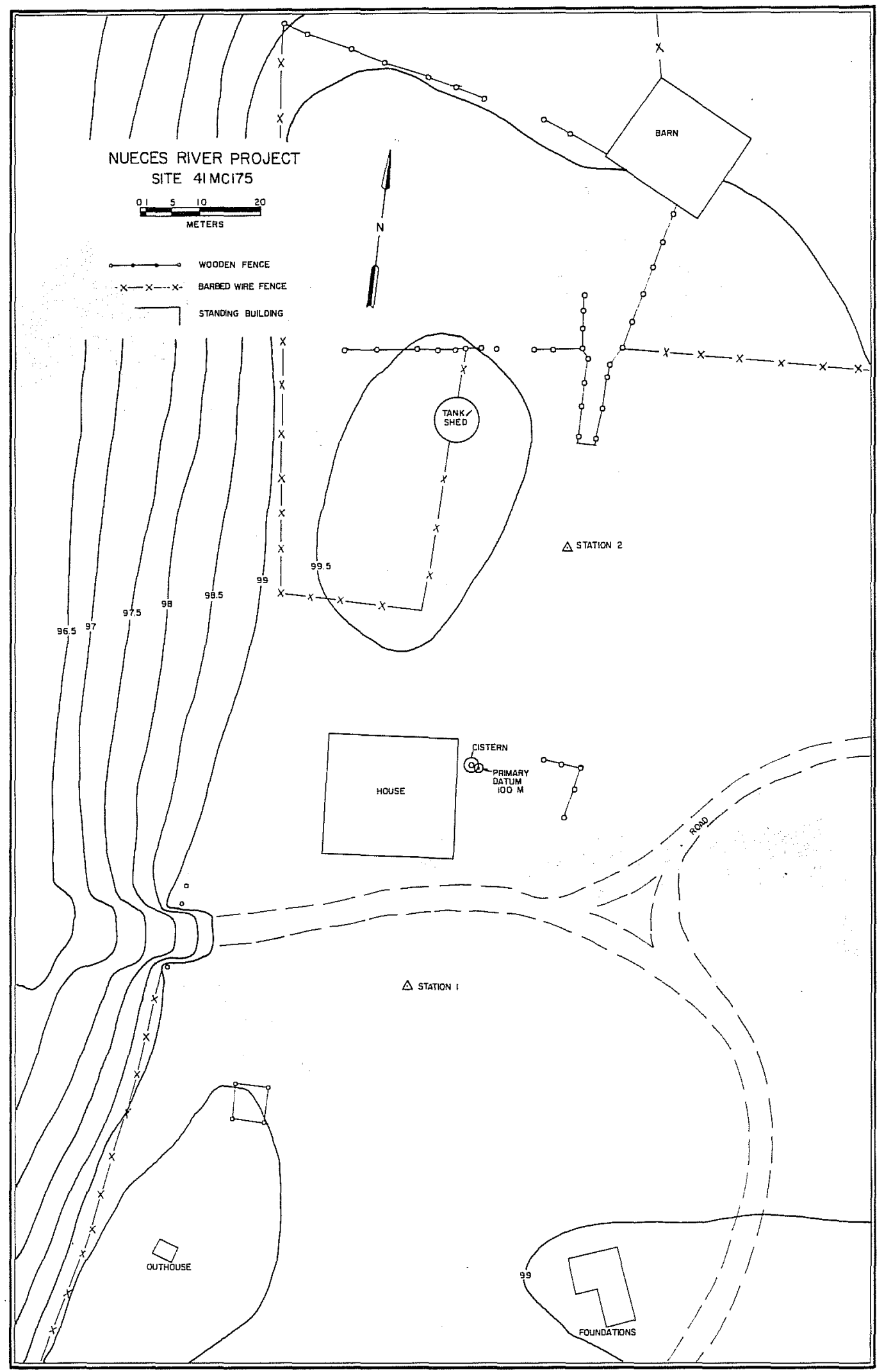

Figure 29. Site Map of 41 MC 175. 
of concrete which could have been a shop or garage. On the south side of the barn is a wooden (pole, log and plank) fence with a cattle loading chute.

The house (Figs. 30,31) is partially collapsed and is constructed on wooden piers. There are five rooms and a screened-in front porch with the middle two room sections of the house apparently having been built before the other three rooms and porch. The end elevation of the house contains a view of a seam in the wall which was probably the roof for the original smaller house, a new and larger roof being installed at the same time that the extra rooms were added on. The temporal separation between the two constructions is unknown. (The elevations and the floor plan do not exactly coincide in detail. The present drawings are made from field sketches. A photograph of the house appearing in Lynn, Fox and O'Malley (1977:181) suggests that the gable line, east windows, or the northern interior wall may be slightly mislocated in the drawing.)

Surface collections were made of the area by extending a diagonal line out from each corner of the house and dividing the site into quadrants. Each quadrant included one specific house corner to the next corner, and from the house out to an arbitrary point at which the artifact density was significantly lower and collecting was not attempted. A dump area on the hillside to the west of the house, and areas around the barn and near the outhouse were collected separately. No areas were tested with excavation.

\section{Artifacts}

The artifacts (Table 7) indicate this house to have been a habitation since the early 20 th century. There is a distinct lack of decorated ceramics, a trend pointed out at other sites also. The glass items include a "special" class of wares not recovered at other sites, specifically a mug and a goblet. There is an occurrence of brightly. colored bottle and vessel glass, and a plethora of kitchen gadgets and other miscellaneous hardware items. There are several recent vintage cartridges, particularly the $7 \mathrm{~mm}$ and the .222 , which indicate the house to have been used most recently as a hunting camp, an activity which is a temporary habitation in the real sense of the term and probably is associated with some of the other household and hardware items. Plastic toys indicate a family may have lived in the house recently.

\section{Chronology}

Only a few artifacts can be dated (Table $8 j$ ): an applied bottle lip and some square cut nails (Table 9). Both of these items, however, date well into the 20 th century. The balance of the items date the house as occupied as a regular family residence since the early 20 th century until perhaps the 1960s, when it was apparently converted into hunting quarters. 

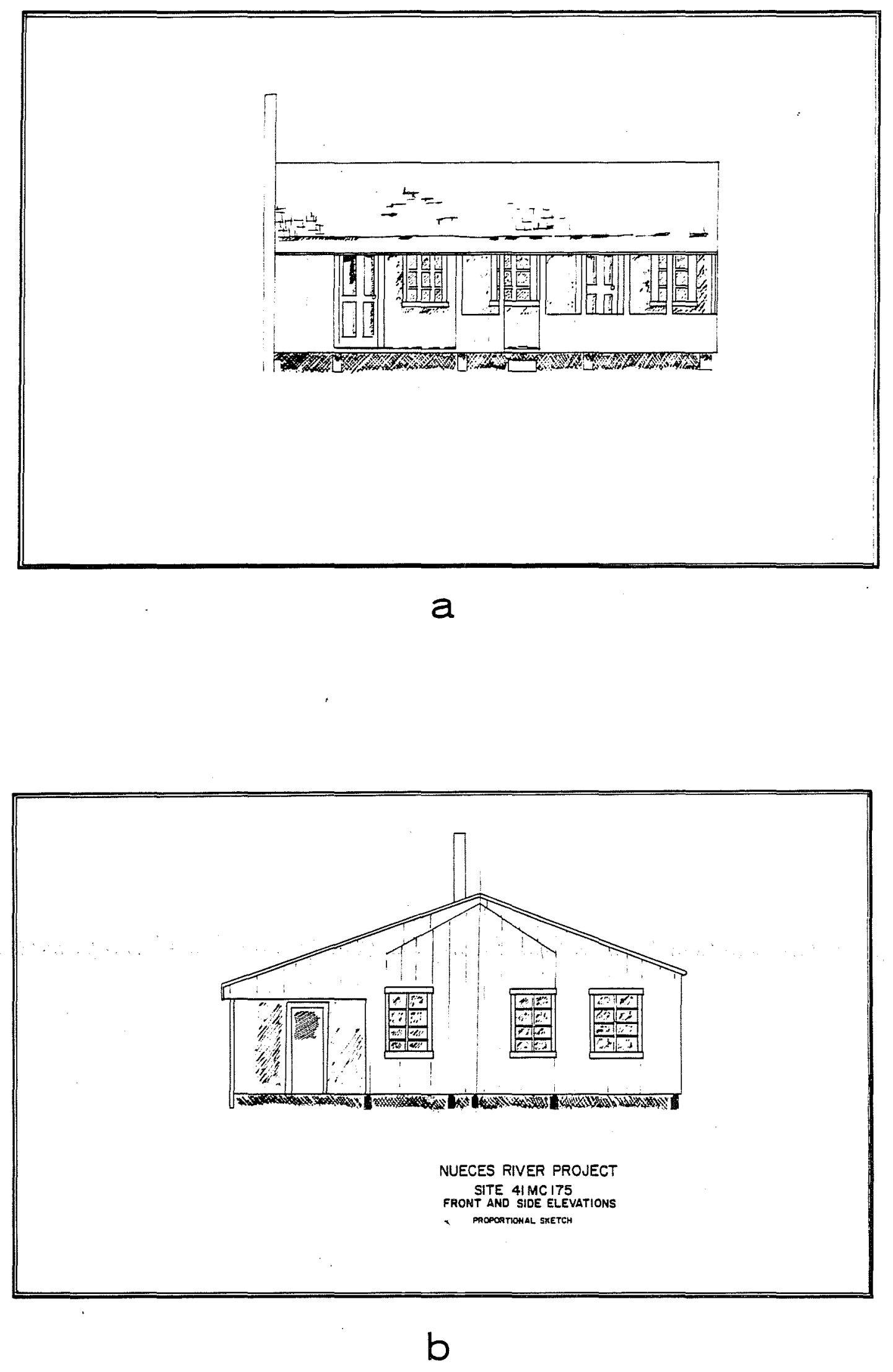

Figure 30. Elevations of Extant House, 41MC175. a, front view; $b$, side view. 


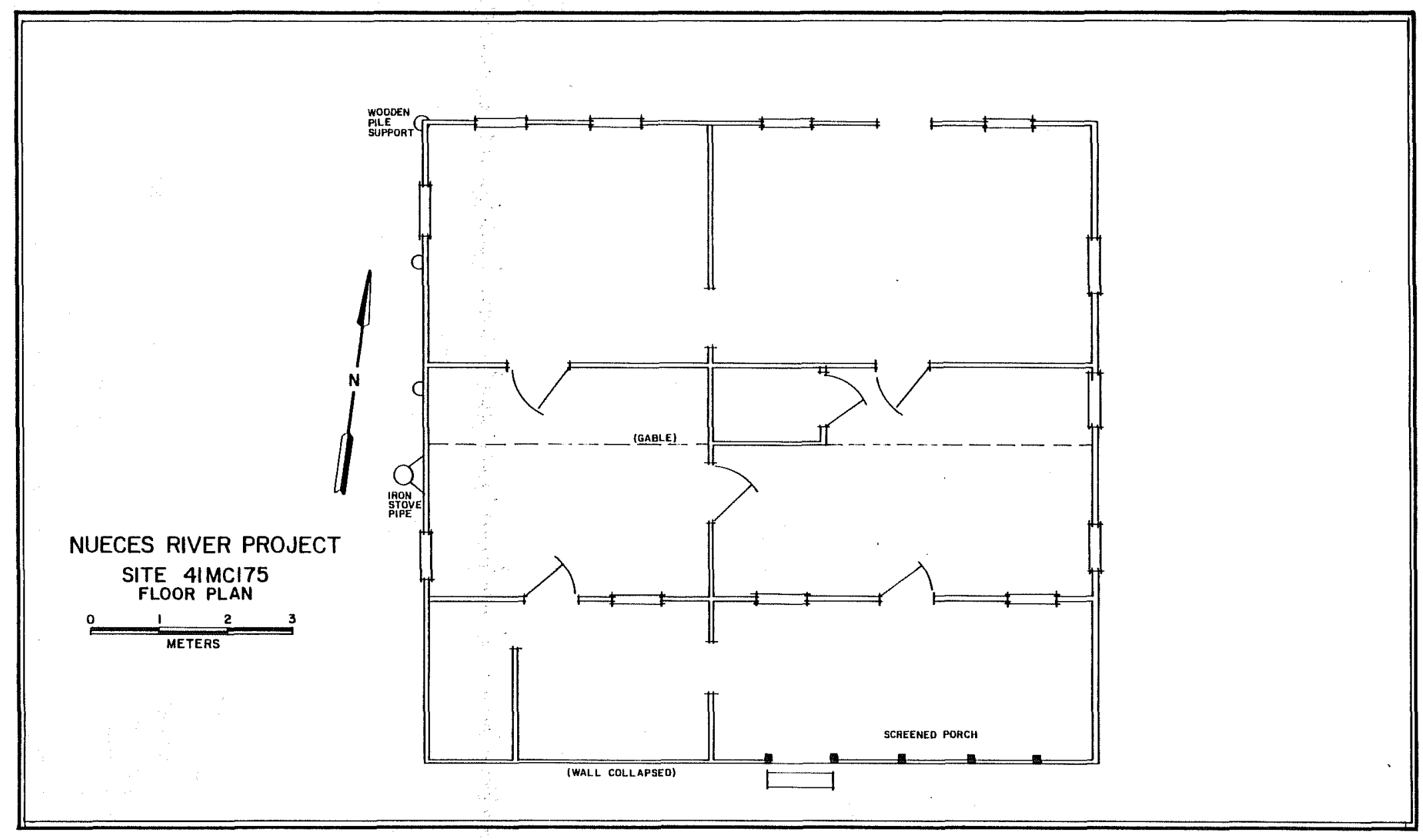

Figure 31. Floor Plan of $41 \mathrm{MC} 175$. 
Eight bottle sherds with maker marks were examined from MC175. One sherd exhibits the Ball Bros. mark which was used in various styles from 1888 until the present (Toulouse 1971:66-68). Two glass sherds show the Hazel-Atlas Glass Co. mark which was used from 1920 through 1964 (Toulouse 1971:239-242). One sherd has the maker mark of Brockway Glass Co. of Brockway, Pennsylvania. This company started operations in 1925 (Toulouse 1971:5962). Four sherds have the Owens-Illinois Glass Co. mark. Of these sherds, two show the number of the plant at Alton, Illinois for 1929-1954; one shows the number of the plant at Newark., Ohio, and the production date of 1932; and the last refers to the plant at Bridgeton, New Jersey from 1929 through 1954 (Toulouse 1971:403, 405-8, 395). Seven ammunition cartridges from MC175 were examined and dated. A .45 Colt made by Union Metallic Co. exhibits a balloon head primer, thus dating between 1873 and 1930 (Barnes 1972:172). Two .222 caliber Remington Super X cartridges, introduced in 1950 (Barnes 1972:34), are among the variations of the cartridges. Two .30-06 Springfields make up the remainder of the collection from this site. This cartridge was adopted in 1906 for the model 1903 Springfield service rifle. The .30-06 is actually a slightly modified version of the original 1903 cartridge. This improved round was designated the "Ball Cartridge, caliber.30, Model of 1906, but in practice the nomenclature was shortened to .30-06" (Barnes 1972:38).

\section{MC185 (Surface Collection and Intensive Testing)}

\section{Description}

The site (Fig. 32) has four sandstone rock concentrations and associated scattered historic occupational debris. The site is situated on a prominent point or ridge overlooking the Frio River, which is about $90 \mathrm{~m}$ to the west. Covering an area of $60 \mathrm{~m} \mathrm{x} 120 \mathrm{~m}$, the site materials are concentrated mostly in the northern end of the site, where the two largest rock concentrations are located. The site has been disturbed by bulldozed senderos (local term for linear clearances) and perhaps some root plowing. Close examination and one test pit indicate that probably no architectural remains are intact enough for fruitful study.

The largest of the sandstone concentrations, feature \#1, is a possible chimney foundation. This feature is situated in the northern part of the site and is very badly disturbed by a road cut ("sendero"), which goes right through where the house itself probably was, and possibly by root plowing too. Figure 26, c, shows feature 非 as an accumulation of sandstone rocks about $4 \mathrm{~m} \times 5 \mathrm{~m}$, many of which are semi-shaped and therefore similar to rocks used in other area site chimney foundations. There is enough rock present to indicate that robbery of stones was probably not the primary cause of the disturbance. The rocks appear to be still present, only jumbled. This evidence as well as the relatively uniform small size of the brush on the site indicates the area may have been chained and then root plowed. 


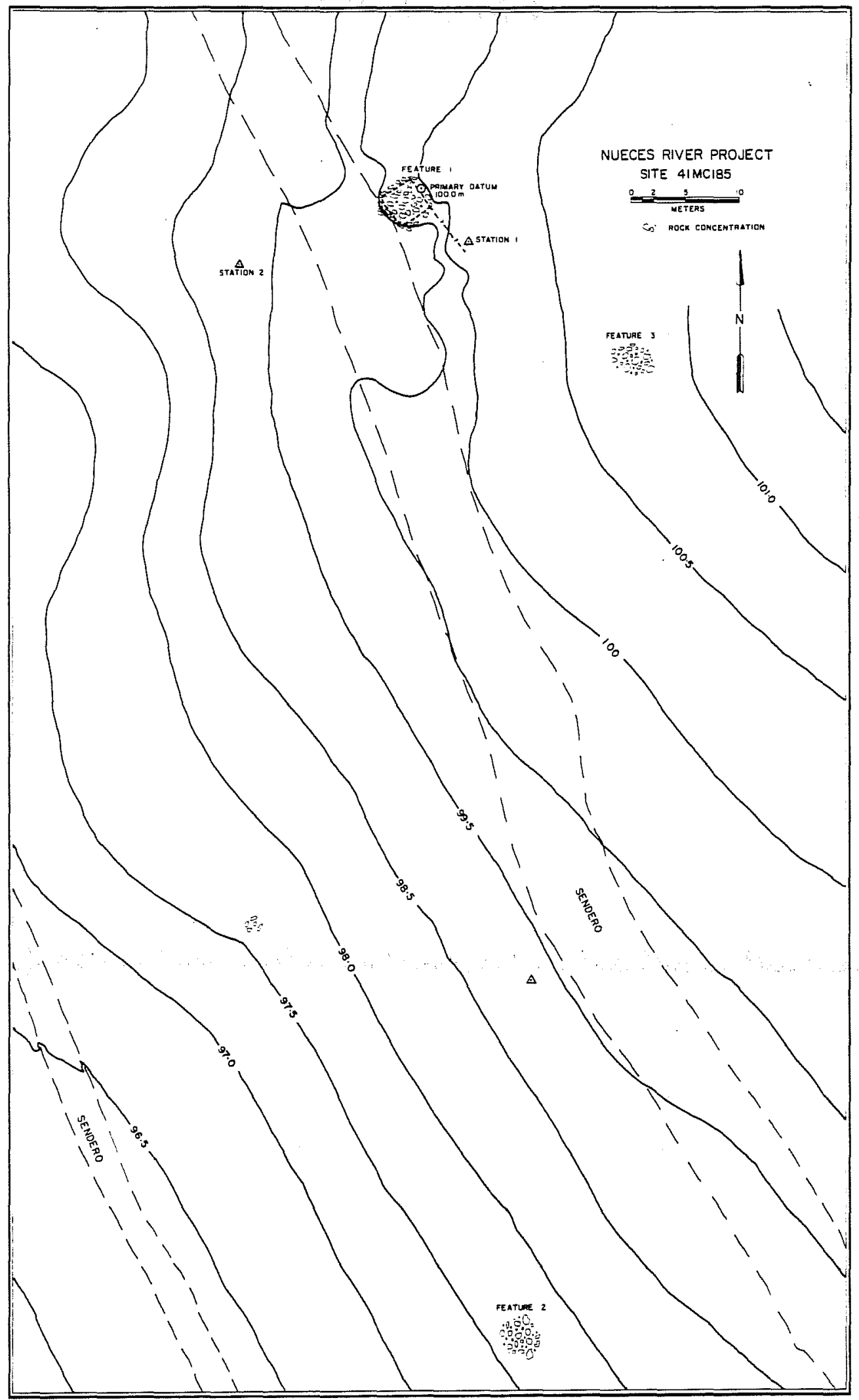

Figure 32. Site Map on 41MC185. 
Feature $f_{3} 3$ is a sandstone rock concentration $24 \mathrm{~m}$ southwest from feature $k_{1}$ which is of unknown function. The rocks in this feature, unlike feature $\equiv_{1}$, are not buried or embedded, but are scattered on the ground surface. Feature k2 (Fig. 26, d), in the south end, is shallow, as is a very small and unlabeled rock concentration $45 \mathrm{~m}$ northwest from feature 非. Feature 非 2 is a group of slabs $0.5 \mathrm{~m} \times 2 \mathrm{~m}$ in size. There are numerous scattered rocks nearby which indicate that it is also disturbed and was probably much larger than the present concentration would indicate. All rock concentrations except feature 非 are of unknown function. They could be pieces of the original chimney that have been pushed or pulled from feature 非 to their respective locations by bulldozing and chaining activity, or they could represent outbuilding structures of some type that are associated with the original house structure represented by feature $\|_{1}$. These concentrations probably do not represent other habitation structures due not only to their dissimilarity of structure (or lack of it), but also due to a distinct absence of occupational debris compared to the feature 非 area.

\section{Artifacts}

This site is a habitation locality with evidence (Table 7) of a structure and associated outbuildings. There are a few decorated ceramic sherds and some majolica tin enameled ware indicating some type of ties with Mexico. Most artifacts, including all "habitation" type debris and nails (Table 9), are associated with the house location. .

\section{Chronology}

The items indicated on the chronology chart (Table 8k) place the probable period of occupation in the late 19th century. The chronological significance of majolica ware is discussed extensively by others (e.g., Lynn, Fox and O'Malley 1977:188, 191) but will be considered here only as a broad time indicator.

The temporal span for MC185 was indicated by several factors. The .44 caliber Henry Flat was again present, indicating a date post1860. A ceramic maker mark, probably that of Bridgewood and Clarke of Burslem, England, was produced between 1857 and 1865 (Godden 1964: 101). Of two identifiable tin cans from this site, one is a body portion with a soldered side seam which was produced from 1815 to 1920 when fold locked seams started replacing the soldered seam (Fontana and Greenleaf 1962:73). The other example is a body portion of the tapered "corned beef type" can which started about 1875 (Fontana and Greenleaf 1962:73). Two marked panel glass sherds, which were not produced until the 1860 s, are present in the collection. 
41MC192, Dusek Site (Surface Collection and Intensive Testing)

Description

This site (Fig. 33), named the Dusek site after Melvin Dusek, foreman for the ranch on which the site is located, is situated on a point of land about $120 \mathrm{~m}$ south of the Frio River. Remains at the site include scattered sandstone blocks, a rectangular house foundation, chimney foundation (Fig. 34, a) and scattered historic occupational debris. A total of three test pits was excavated, recovering occupational debris and encountering architectural remains. In addition, controlled surface collections were made.

The sandstone rubble is scattered broadly over the site; much of it is surface scatter, but there is some aligned distribution pattern (Fig. 34, a). The chimney foundation is situated in a central part of the east edge of the stone rubble and oriented with a long axis aligned with the rubble. The hearth is about $2 \mathrm{~m} \times 3 \mathrm{~m}$ in size and has two or perhaps three courses of slabs remaining (Fig. 35). If the rectangular stone rubble is representative of the original house dimensions, the chimney would be situated in the middle of the east wall of a rectangular structure measuring about $5 \mathrm{~m} \times 15 \mathrm{~m}$.

The degree to which the surface rubble represents the actual house architecture is not known except in one test pit, \#3, (Fig. 34, b). Situated on the west side of the structure opposite the chimney foundation, the Im $x .75 m$ pit encountered a feature at about $8 \mathrm{~cm}$ below the ground surface which is apparently some type of wall footing or other architectural feature. The ground surface in this area was littered with sandstone blocks, as can be seen in Figure 34 , c. Stone

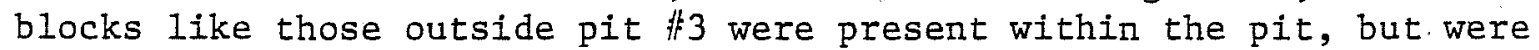
not buried to any depth and were removed prior to the photograph. In the same Figure ( $34, \mathrm{~b})$, there is visible a clustering of small sandstone rocks in the northwest floor corner of the pit. This is the footing feature which extends outside the pit to the north and west, is relatively circular in outline on the edge excavated, and is about $8-10 \mathrm{~cm}$ thick. The top surface of the gravel feature increases in height to the $\mathrm{NW}$, which is toward the central area of an extensive sandstone block concentration. The floor of test pit \#3, subsequent to excavating to $20 \mathrm{~cm}$ level, was brushed, troweled, and dampened with water spray, revealing several soil stains which may also be architectural features. One linear dark stain was oriented northwest/southeast across the floor of the pit, parallel in axis to the chimney foundation. Another stain (10-15cm, circular) was located to the west of the linear stain under the edge of the overlying gravel lens feature (Fig. 34, d). These stains may represent a post and wall trench associated with the structure or may be merely a rodent burrow with a fortuitous orientation. The stone scattered on the surface of the site could also have been fortuitously aligned by a bulldozer cut, but the surface features in test pit \#3 indicate that this is not the case. More testing should disclose the correct answer. 


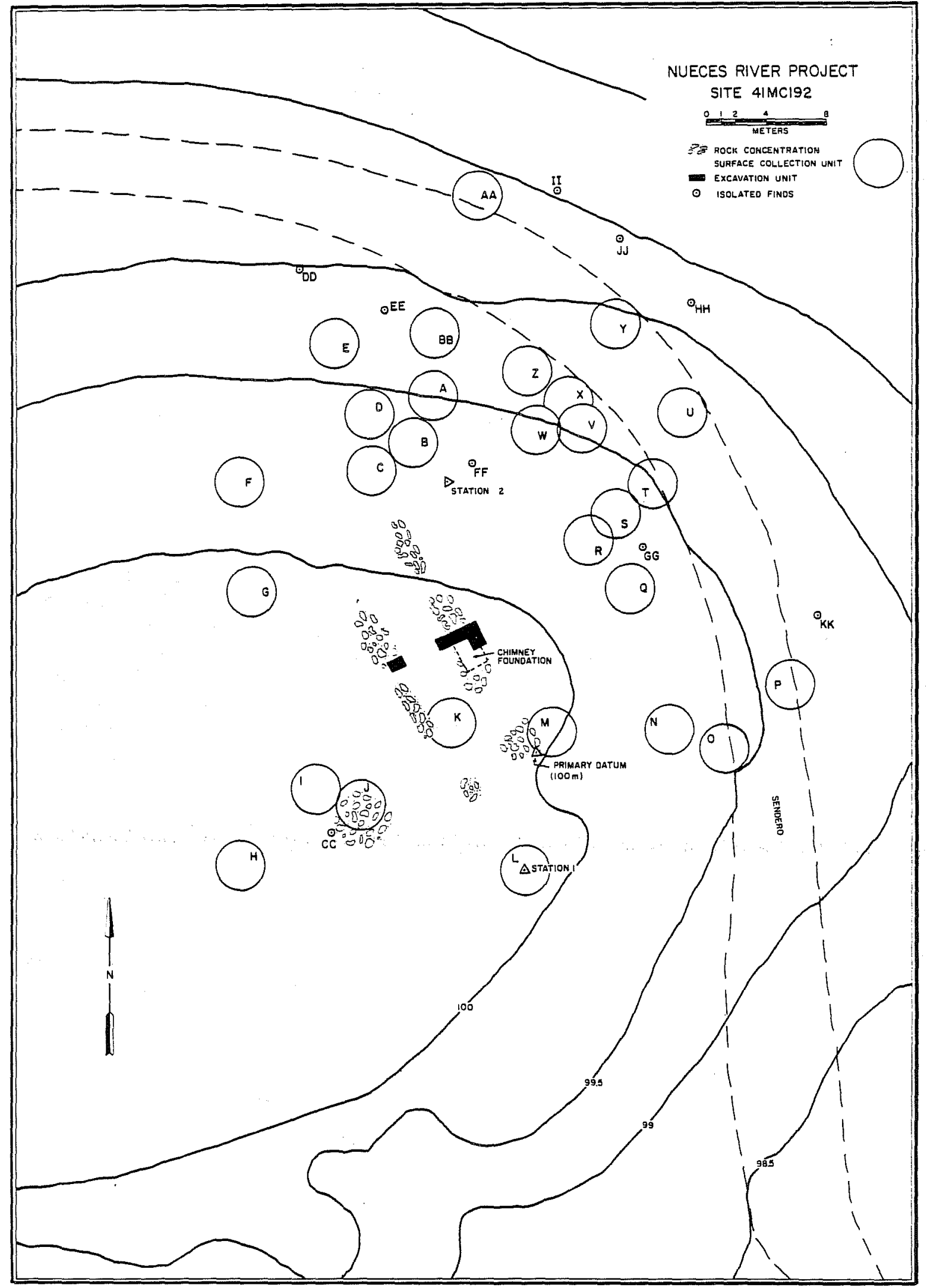

Figure 33. Site Map of 41 MC192 (the Dusek Site). 


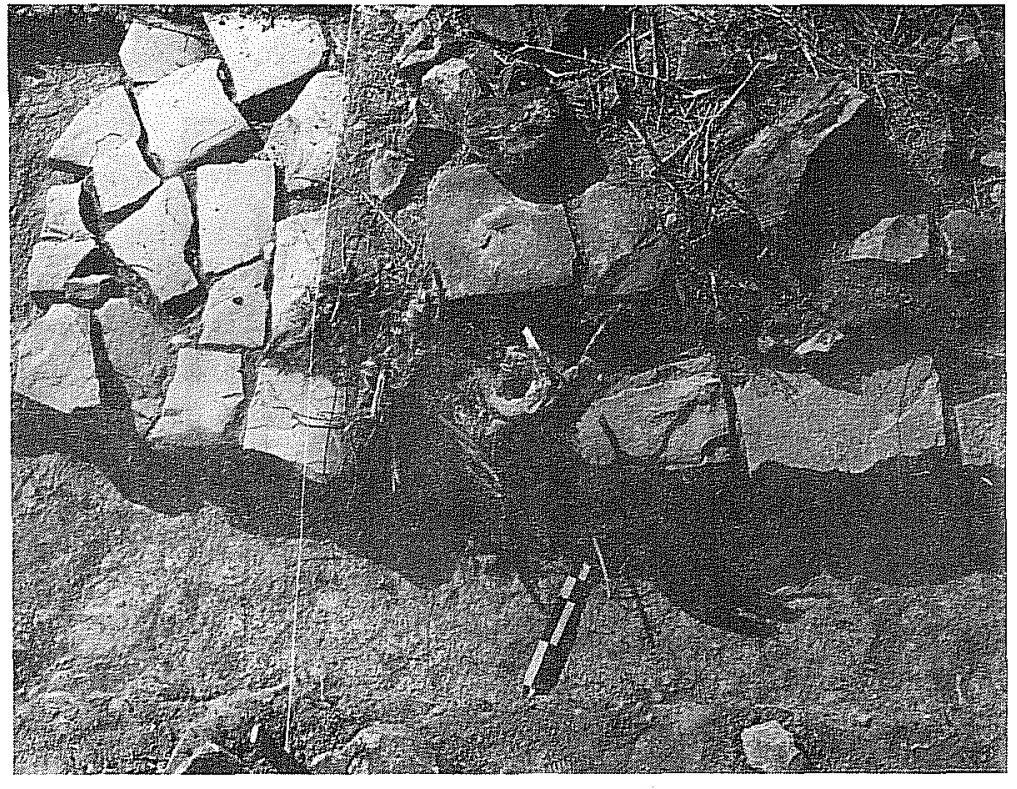

a

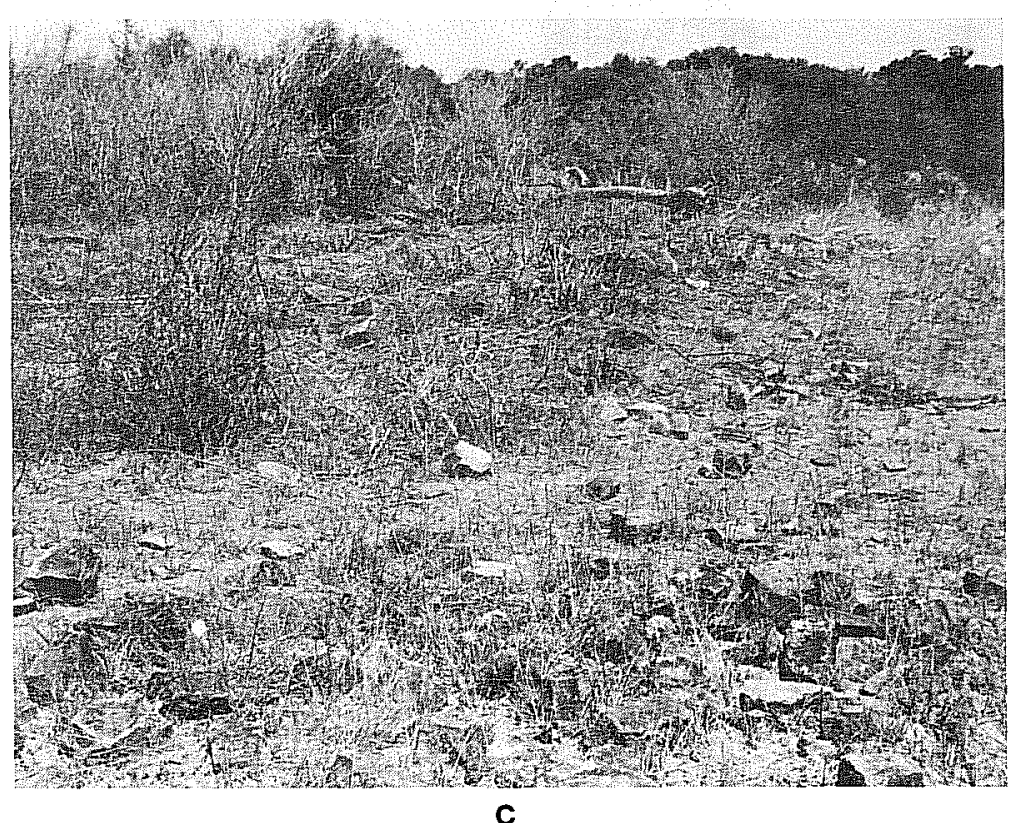

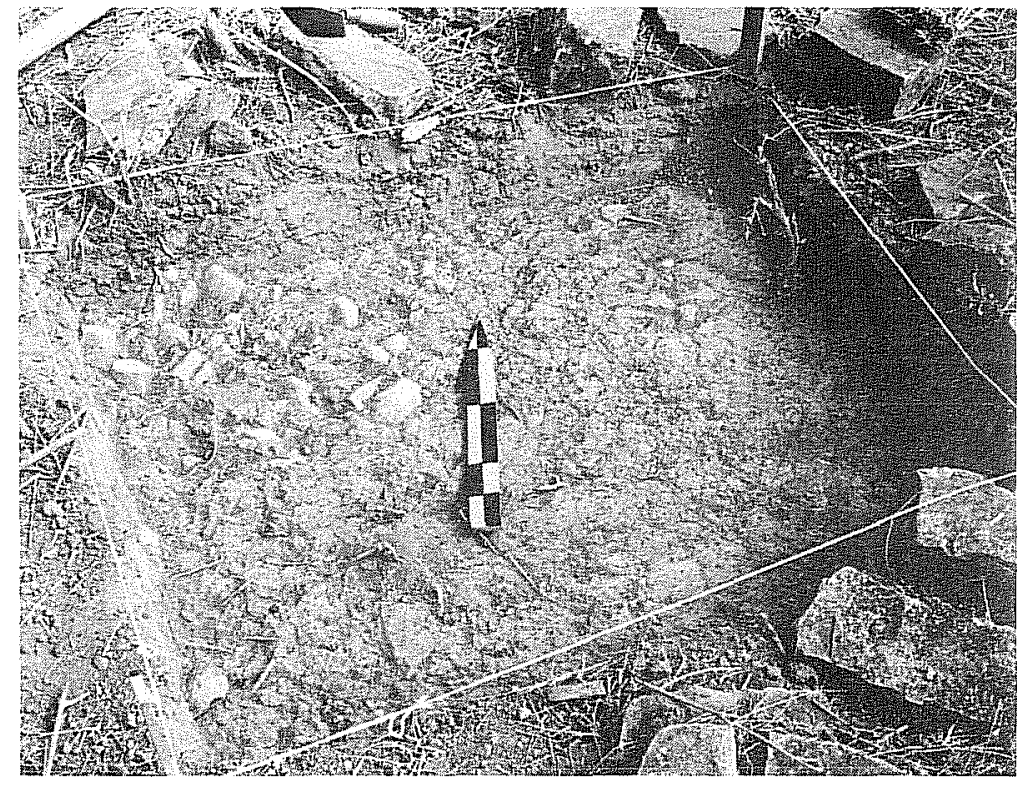

b

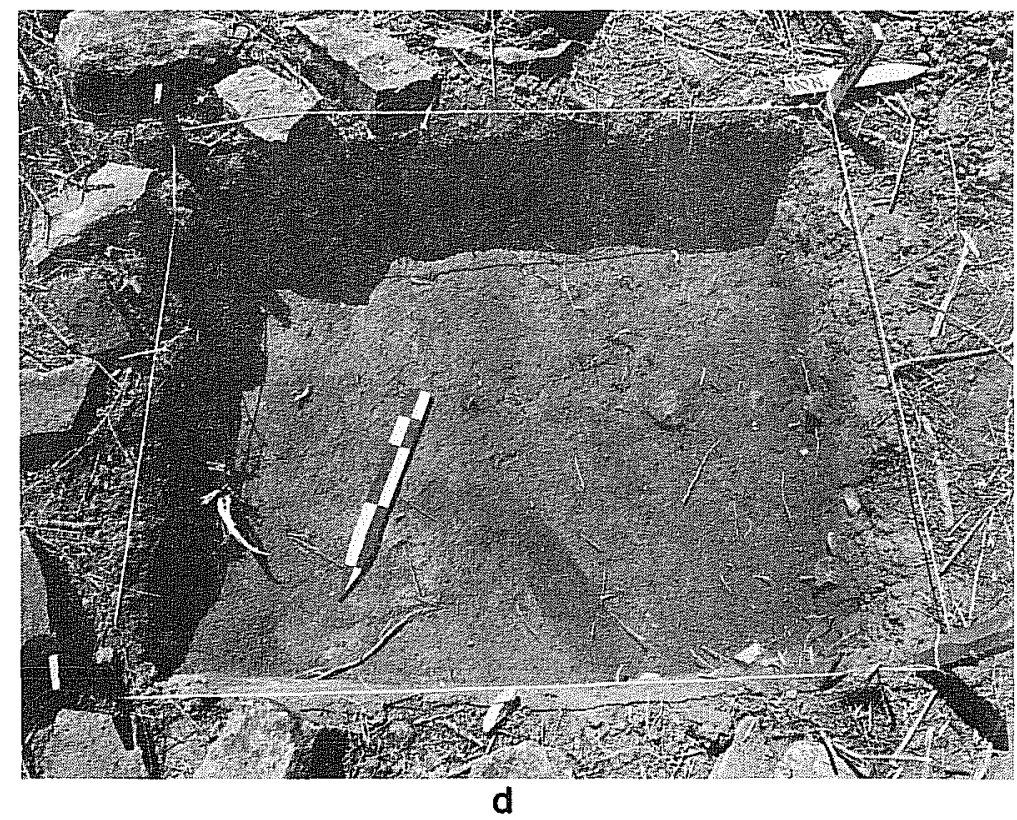

Figure 34. Photographs of 41MC192. a, chimney foundation; $b$, test pit 33 , level 1 , showing lens feature; $c$, general view of site; d, test pit $\# 3$, level 2 , showing stain in floor. 


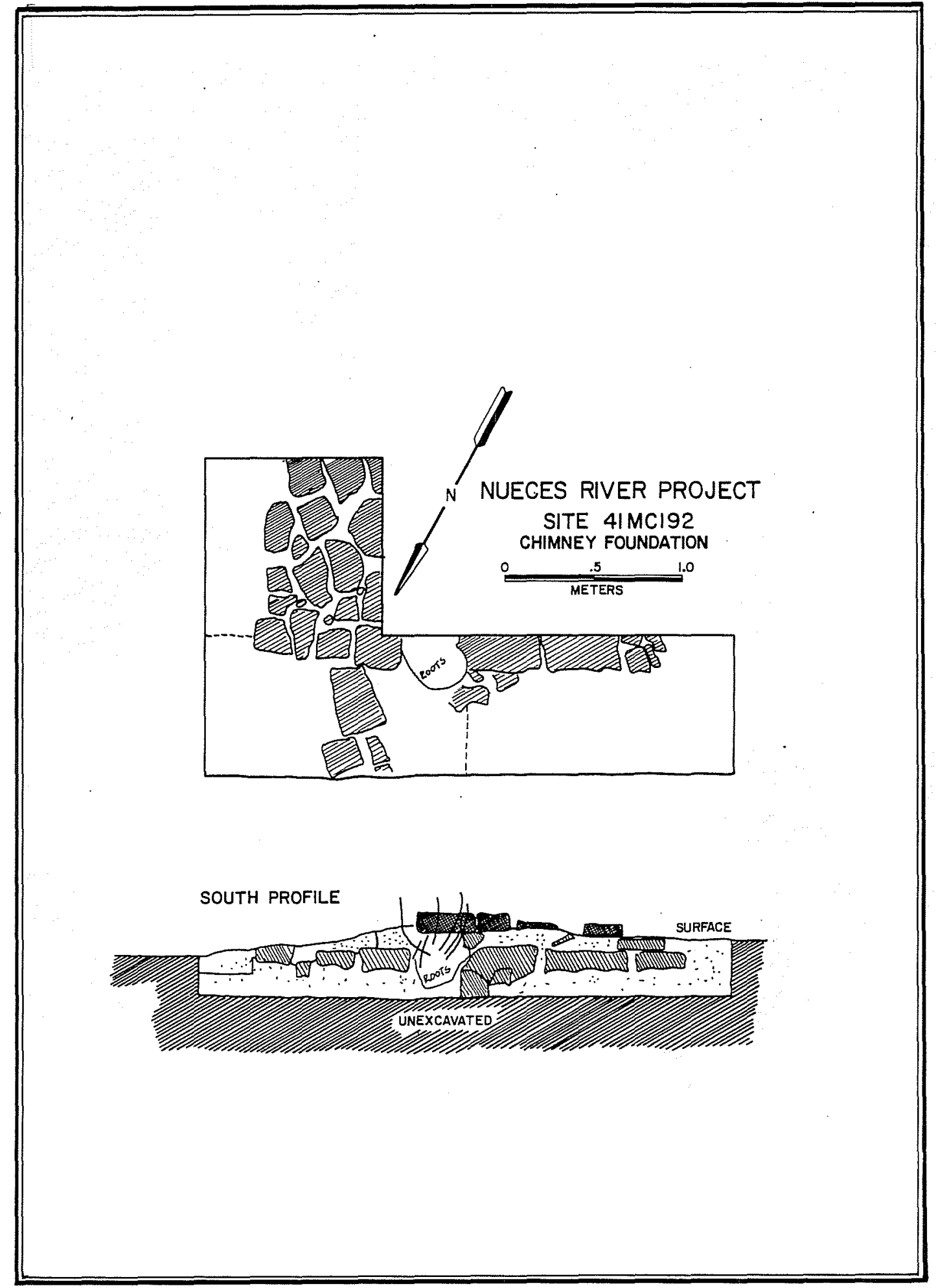

Figure 35. Chimney Foundation and South Profile, 47MC192. 
Another architectural detail of note is the northward extension of slabs adjacent to the chimney foundation. Having only one course of flat aligned slabs, this feature was not delineated enough to warrant calling it a wall, but it may be a wall feature comparable to those at $41 \mathrm{MC} 15$ and 41MC46. The position of this wall feature indicated that the chimney extended into the room over one meter. The presence of a wall trench inside the structure from a layer of gravel may indicate an interior jacal or picket wall and an external rock wall (the gravel being a footing for the stone wall).

An isolated concentration of stone in surface collection unit $\mathrm{J}$, to the southwest of the main structure, may represent an outbuilding, but the structure of this feature was not investigated. Other stones were scattered over the entire area, but these are due mainly to the disturbance of the site by brush clearing. Sheet erosion is evidenced over the whole site area, but is most pronounced in the northeastern part of the site where the majority of occupational debris is found. The prolific occurrence of this material in such a restricted area may be due to having been the original dumping area or may be a function of differential exposure by erosion. If the concentration is due to actual material distribution, the location of the house doorway is suggested as being on the northeast part of the structure. South (1977:47) has reported the Brunswick refuse disposal pattern in North Carolina which reflects elements of site structure, content, context and function. One element of this phenomenon is the association of certain classes of refuse with structure doorways or gates. The applicability of this British-American pattern to the south Texas frontier is rather tenuous, but the idea should certainly be further explored. As the door location is presently unknown, resolution of this problem must await subsurface archaeological investigations.

In October, Bandy visited the site, and because recent rains had exposed more artifacts, a few of the more significant items were collected. Each collected item was mapped relative to the still-exposed chimney foundation and plotted on the site map. The exact positions were determined by standing a ranging pole at the exposed corner of the chimney foundation and then standing over the artifact to be mapped in. The distance back to the ranging pole was measured with a range finder optical instrument and an azimuth reading made with navigational compass. Items which were located in original surface collecting circles were included with those previously collected items, and items collected outside of original circles were mapped as isolated finds (Fig. 33).

\section{Artifacts}

The wide variety and quantity of items recovered at this site (Tables 7,9 ) are unusual for the project sites and are apparently the result of the economic affluence of the inhabitants. The occurrence of many decorated ceramics has certainly the highest frequency at any of the project sites. The scarcity of window glass is interesting 
because it indicates that the assumption that windows are a status commodity may not be a valid concept in this mid-19th century setting. Noteworthy in the metal class is the fish hook (Fig. 9, g). This is the only evidence in the project area to date of any inhabitants exploiting the Frio River for other than water. Note also the metal kitchen utensils.

\section{Chronology}

The abundance of materials at this site allows for a much better date estimate (Table 81) than is possible at most of the project sites. The most notable item is the coin (Fig. 11, d), which is a Mexican five centavos piece dated 1870. Not only is this date useful, but the fact that it is Mexican in origin confirms the Mexican contact indicated by the presence of majolica at $41 \mathrm{MCl} 85$ and indicates that this contact may be more than just a casual association or "tourist visit." Another unusual item is the tumbler part of a muzzle loading percussion rifle which has been suggested to date post-1830 (personal communication, Guy Wilson).

Two ceramic sherds with maker marks are present from this site. The first (Fig. 6, j) represents Bridgewood and Clarke of Burslem, England which operated from 1857 through 1864 (Godden 1964:101). The second example has two possibilities: first, Alfred Meakin of Tunstal1, England which operated from 1875 through 1897 (Godden 1964: 425), and second, J. and G. Meakin of Hanley, England which has operated since 1851 (Godden 1964:427). Three marked glass panel sherds represent post-1860 manufacture. An ink bottle (Fig. 28, d) has an applied lip and was made in a cup bottom mold.

Three top portions of tin cans show hole-in-the-top manufacture which was used from approximately 1815 to 1900 . The can, at this early period, was laboriously cut from tinplated sheet iron by hand or footpowered scissors; the body then was formed around cylinders and the seam soldered. Separate pieces for the top and bottom were cut and soldered. A hole was left in the top through which the food was forced. A smaller cap was finally soldered in place after filling. A pin hole in the cap allowed gases to vent. One last drop of solder sealed the job. This type of can became known as the "hole in top" or "hole and cap" (Fontana and Greenleaf 1962:68-69). Two body portions of tin cans show soldered side seams which were used from 1815 to about 1920 (Fontana and Greenleaf 1962:68-69, 73).

41MC193, Bracken Site (Surface Collection and Mapping)

\section{Description}

This site (Fig. 36), named after Sam Bracken, the landowner, is located on a hill overlooking the Frio River which is about 150m to the north. The site has two main parts: 1) a habitation locality 


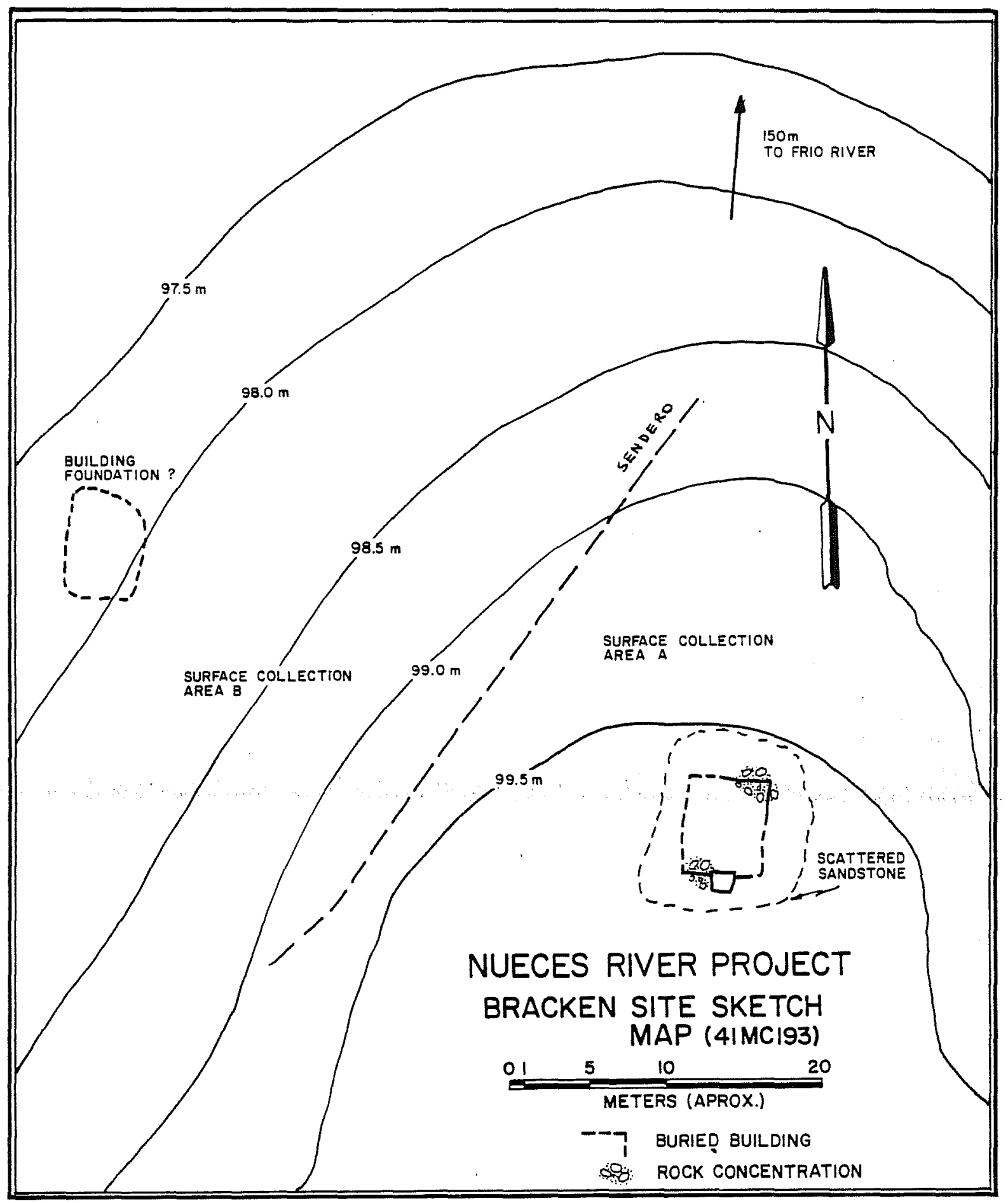

Figure 36. Bracken Site Sketch Map, 41 MC193. 
(Fig. 37, a) with sandstone chimney foundation (Fig. 37, b), scattered sandstone, and historic occupational debris, and 2) a small scattering of sandstone which may represent an outbuilding foundation to the west of the house. The habitation structure is rectangular in outline, with remnants of slab alignments. Sheet erosion has been moderate, with probable past disturbance by brush clearing and much recent damage by hog rooting. A sendero crossing the site between the outbuilding and the house was used as a demarcation line to surface collect the site in two areas, A and B. Area B is associated with the outbuilding foundation, and area $A$ is on the south side of the sendero and associated with the habitation site. As at site 41MC192, surface collections were made subsequent to the summer field season, with the collected items incorporated with those previously collected by areas. No test excavations were made, but animal burrow profiles and backdirt indicate this site to be very similar to 41MC192, which is only about $390 \mathrm{~m}$ to the west.

\section{Artifacts}

The artifact assemblage (Table 7) is very similar to that of 41 MC192 except that there are not as many decorated ceramics nor such a wide variety of items. This site is a habitation structure dating in the mid-19th century. There is a prehistoric site component.

\section{Chronology}

Datable objects (Table 8m) include the common ceramic and glass types of the late 19 th century, square cut nails (Table 9), tin cans, and a gun part. This particular gun part (Fig. 11, b) is a trigger assembly of a muzzle loading type rifle which was probably mass produced from a stock pattern. The exact type of gun is unknown, except that it is not a Sharp's rifle; it is probably a Civil War era piece, dating from perhaps as early as 1850 but most probably later. This type of gun part is still made today, but is not commonly used except as a novelty (Guy Wilson, personal communication).

A single top portion of a hole in top tin can appears at this site suggesting a manufacture date for this specimen circa 1815 to 1900 (Fontana and Greenleaf 1962:68). A marked panel glass sherd, produced after 1860 , is also present.

41MC194, Horton Site (Surface Collection and Mapping)

\section{Description}

The Horton site, 41MC194, is approximately 120m south of the Frio River and $630 \mathrm{~m}$ west of Black Hill Hollow (approximately $110 \mathrm{~m}$ west of Horton/Bracken fence line). Roughly round, the 


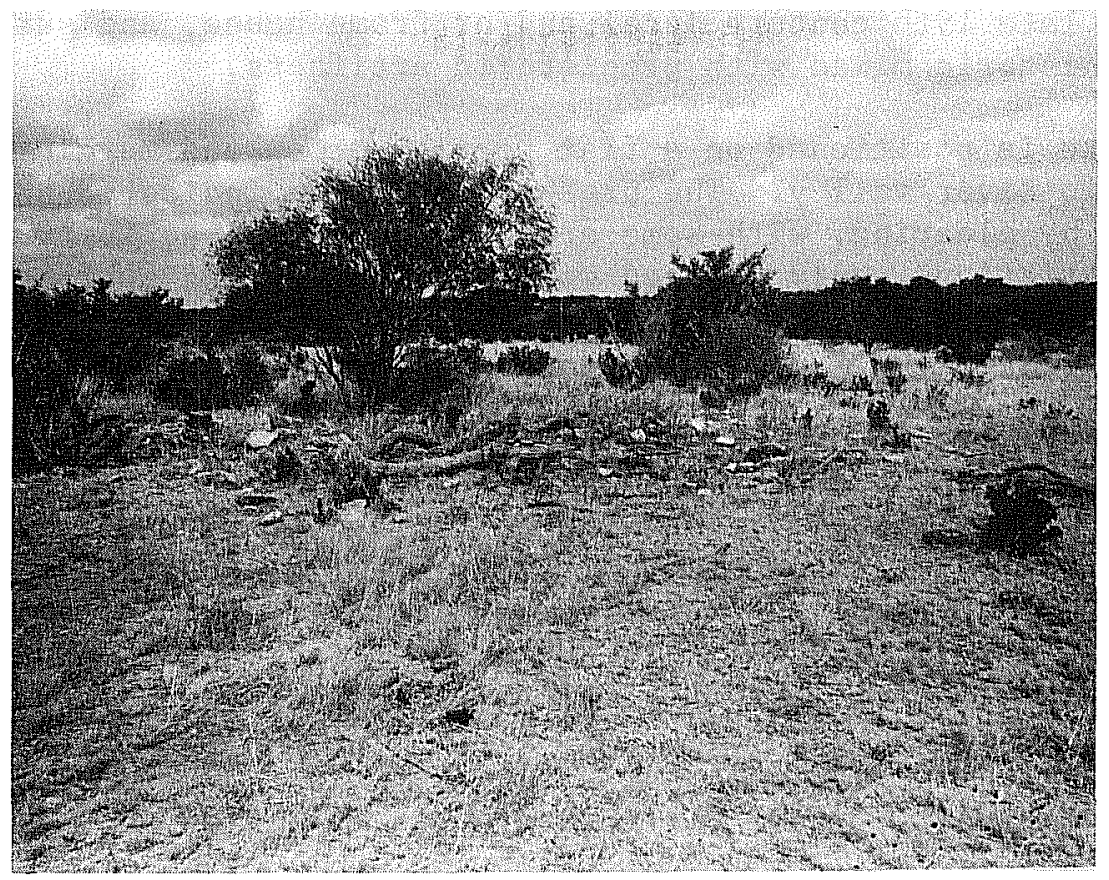

a

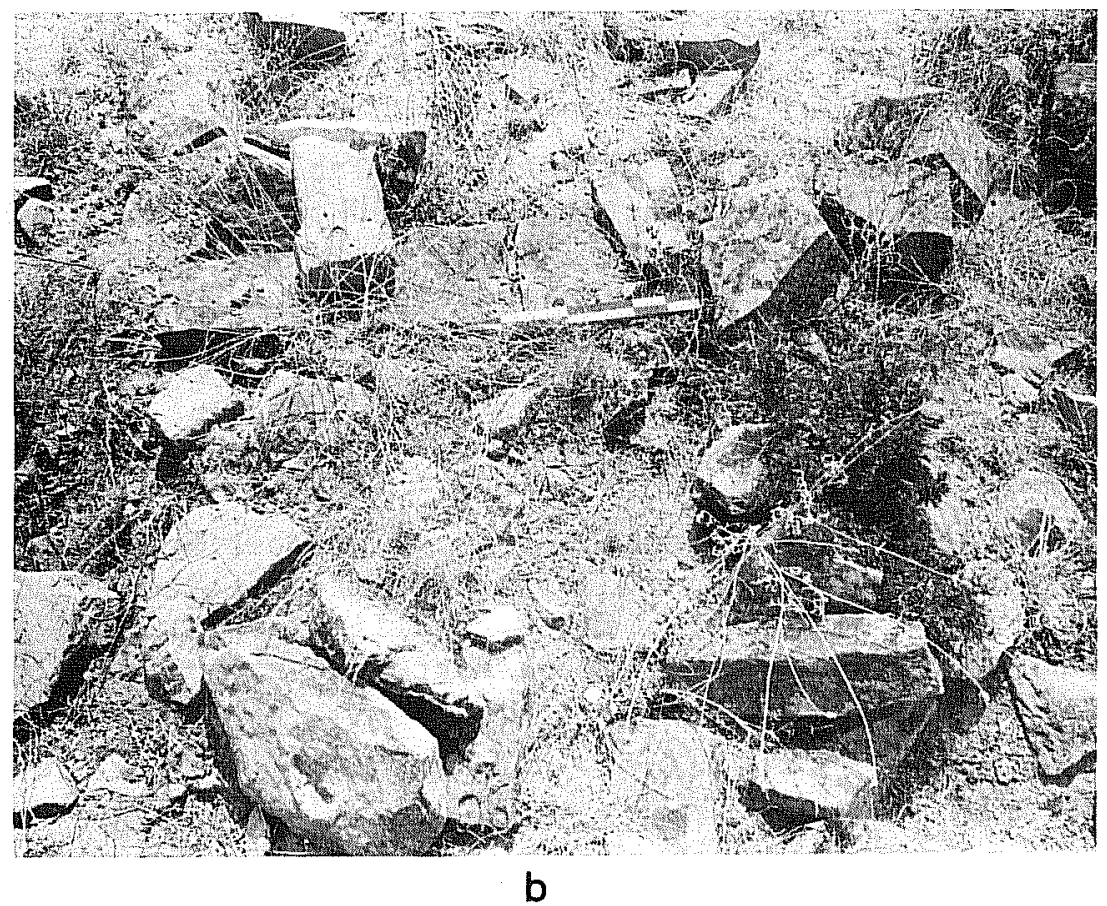

Figure 37. Site 47MC193. a, general view of site; b, chimney foundation. 
site has a 30m diameter. Features are indicated by the foundation stones of a late 19th century jacal and/or frame house, and surface scatter of historic mixed with prehistoric artifacts.

The site is positioned on a flat portion of upland margin sloping into the Frio River valley. The present condition indicated possible disturbance by clearing, with some erosion and animal activity. Due to time restrictions, only limited work (sketch map and surface collection) was carried out.

\section{Artifacts and Chronology}

The materials (Table 7) reported on the survey form seem much the same as for the other sites of the project area, consisting of 19 th century glass, ceramics, and metal (square nails). The absence of wire nails (Table 9) along with the other material indicate a general date during the late 19 th century for this site.

4IMC195, Teal House. (Surface Collection)

\section{Description}

This site, known as the Teal House, appears to be a late 19th century habitation and ranch house. All that remains above surface are the scattered sandstone blocks of the now destroyed house foundation and the usual remains of cultural debris, including ceramics, glass and metal. The site, with a sandy clay surrounding soil, is situated in the Frio River drainage system.

\section{Artifacts}

Although the limited amount of material (Tables 7, 9) makes it difficult to elaborate on the functions carried on at the Teal House, the artifacts represent the typical late 19th century (Table 8n) homestead assemblage. A unique item recovered was a porcelain door knob. This was the only one found in the entire project area.

\section{Chronology}

The Teal House collection exhibits a .44 caliber Henry Flat which was used after 1860 with the Henry repeating rifle (Logan 1959:68). Also, a ceramic sherd with the $E$. and $C$. Challinor maker mark of Fenton, England is present. The Fenton Pottery operated from 1862 through 1891 (Godden 1964:137-8). 


\section{SUMMARY AND CONCLUSIONS}

The historic sites investigated during this project recall a way of life during American frontier expansion and development that has almost been forgotten in its "nitty-gritty" details, although it has been romanticized in popular memory and lore. Such details are recovered through both archeological and historical research, each contributing information to be used in answering questions about "who lived here and when?" and "how did they live?"

Attempts to answer such questions about the inhabitants of these sites. were made by three independent investigators during this project. Daniel E. Fox, with his considerable experience in south Texas historic archeology, directed the field work and, while he and his crew worked at the sites, suggested cultural and chronological possibilities. Dianna Everett, working in libraries, county court houses and other archives, visiting cemeteries, and interviewing descendents of frontier families, contributed her answers (see Part I of this report). Philip A. Bandy, directing the lab work on collected specimens from the sites, tried to enable these material culture remains to "speak for themselves." The three sets of "answers" are presented side by side for each site in Table 5 .

It is interesting to note which sets of data answered which questions in this project. Actual ways of everyday life were evidenced in the archeological record. The locations, sizes and construction details of the houses and the amounts and types of household goods remaining indicate a "life style" pretty "near the bone," even for those times. Differences in standards of 1 iving between urban and rural dwellers are suggested; we know (see South 1977:232) that many people in even the earlier frontier towns had some of the material luxuries of the time. People living directly on the outlying farms and ranches probably could not afford them.

None of the archeological data suggested "ethnicity." So far as can be told at this stage of analysis and interpretation, nothing in the archeological record says "an Anglo-American family lived here" or "a Black family lived here" or "a Mexican family lived here," although we know from historical sources that these statements can be made about most of the sites at particular times (Table 5 and as reported in Part I). As far as material culture goes, environmental requirements, subsistence activities and levels of affluence were greater factors than ethnic identities and customs. Being a rather poor south Texas stockraiser dependent on regional and even national market demands was a common experience for persons of various origins, languages, religions and traditions; this common experience is reflected in the material remains of their homes. 
In summary, archeological research is valuable for answering questions about how people really lived in this area (and roughly when), but historical research is necessary to tell us who they were, both as individuals and as members of cultural groups. This is probably true of all archeology and leads us to hazard several generalizations. First, from the historical point of view, studies of material culture (of any time period) are necessary to "flesh out" our knowledge of any people's actual way of life. Second, from the archeological point of view, when historical sources are available, they can offer information not preserved or only faintly detectable in the archeological record. Third, also from the archeological point of view, when historical sources are not available, we must remember that great diversity in ethnic identity, language, politics, religion and in other realms may be reflected very poorly or not at all in the archeological record. This project suggests two major reasons for this last generalization: the ordinary household does not contain much preservable evidence within those realms just mentioned, and, the demands of subsistence may override much of the diversity and help produce a relatively uniform economic way of life for people who are quite different in other important ways. 


\section{REFERENCES CITED}

Barnes, F. C.

1972 Cartridges of the World. Editor John T. Amber. Follett, Chicago.

Davis, E. M. and J. E. Corbin

1967 Archeological Investigations at Washington-on-the-Brazos State Park in 1966. State Building Commission Archeological Program, Report 5.

Fontana, B. L. and J. C. Greenleaf

1962 Johnny Ward's Ranch: A Study in Historical Archeology. The Kiva 28(1-2):1-115.

Godden, G. A.

1964 Encyclopaedia of British Pottery and Porcelain Marks. Bonanza Books, New York.

Goggin, J. M.

1968 Spanish Majolica in the New World: Types of the Sixteenth to Eighteenth Centuries. Yale University Publications in Anthropology 72. New Haven.

Logan, H. C.

1959 Cartridges. Bonanza Books, New York.

Lynn, W. M., D. E. Fox, and N. O'Malley

1977 Cultural Resource Survey of Choke Canyon Reservoir, Live Oak and McMullen Counties, Texas. Texas Historical Commission, Office of the State Archeologist, Archeological Survey Report 20.

Mayer-Oakes, W. J.

1977 Proposal for Cultural Resources Investigation, Archeological and Historical, Phase I, Nueces River Project, Texas, in response to Bureau of Reclamation RFP 50-V0897. Cultural Resources Institute, Texas Tech University.

Munsey, C.

1970 The Illustrated Guide to Collecting Bottles. Hawthorn Books, New York. 
Nelson, L. H.

1968 Nail Chronology as an Aid to Dating old Buildings. American Association for State and Local History Technical Leaflet 48 , History News 24 (11): 1-11.

Schuetz, M. K.

1969 The History and Archeology of Mission San Juan Capistrano, San Antonio, Texas. State Building Commission Archeological Program, Report 11: Volume 2.

South, S.

1977 Method and Theory in Historical Archeology. Academic Press, New York.

Toulouse, J. H.

1971 Bottle Makers and Their Marks. Thomas Ne1son, New York.

Wakefield, W. H.

1968 Archeological Surveys of Palmetto Bend and Choke Canyon Reservoir, Texas. Texas Archeological Salvage Project, The University of Texas at Austin, Survey Report 5. 